\title{
Global phylogeny and taxonomic reassessment of the lichen genus Dendriscosticta (Ascomycota: Peltigerales)
}

\author{
Antoine Simon, ${ }^{1,2}$ (D) Bernard Goffinet, ${ }^{2}$ (i) Li-Song Wang, ${ }^{3}$ Toby Spribille, ${ }^{4}$ (i) Trevor Goward, ${ }^{5}$ \\ Tatiana Pystina, ${ }^{6}$ (D) Natalia Semenova, ${ }^{6}$ Nikolay V. Stepanov, ${ }^{7}$ (i) Bibiana Moncada,,${ }^{8,9,10}$ (i) Robert Lücking, ${ }^{10}$ (i) \\ Nicolas Magain ${ }^{1}$ (i) \& Emmanuël Sérusiaux ${ }^{1}$ (i) \\ 1 Evolution and Conservation Biology, InBIOS Research Center, University of Liège, Quartier Vallée 1, Chemin de la Vallée 4, \\ 4000 Liège, Belgium \\ 2 Department of Ecology and Evolutionary Biology, 75 Northeagleville Road, University of Connecticut, Storrs, Connecticut \\ 06269-3043, U.S.A. \\ 3 CAS Key Laboratory for Plant Diversity and Biogeography of East Asia, Kunming Institute of Botany, Chinese Academy of Sciences, \\ P.R. China \\ 4 Department of Biological Sciences, CW405, University of Alberta, Edmonton, AB T6G 2R3, Canada \\ 5 UBC Herbarium, Beaty Museum, University of British Columbia, Vancouver, BC V6T 1Z4, Canada \\ 6 Institute of Biology, Komi Science Center UrD RAS, Kommunisticheskaya Street 28, Syktyvkar, Russian Federation \\ 7 Siberian Federal University, Fundamental Biology and Biotechnology Department, Svobodnii St. 79, Krasnoyarsk, 660041, \\ Russian Federation \\ 8 Universidad Distrital Francisco José de Caldas, Cra. 4 No. 26D-54, Torre de Laboratorios, Herbario, Bogotá D.C., Colombia \\ 9 Negaunee Integrative Research Center, The Field Museum, 1400 South Lake Shore, Chicago, Illinois 60605, U.S.A. \\ 10 Botanischer Garten, Freie Universität Berlin, Königin-Luise-Straße 6-8, 14195 Berlin, Germany \\ Address for correspondence: Antoine Simon, asimon@uliege.be
}

DOI https://doi.org/10.1002/tax.12649

\begin{abstract}
The genus Dendriscosticta (Ascomycota: Peltigerales) encompasses several distinctive lichen-forming fungal species restricted to the Northern Hemisphere. Most are flagship species of old-growth forests with good air quality. A global phylogeny of the genus based on multilocus sequence data (ITS, RPB1, EF-1 $\alpha, M C M 7$ ), model-based phylogenetic methods, and morphological and chemical assessments, reveals a high level of cryptic speciation often associated with restricted geographical distribution and/or chemical characters. Using sequence-based species delimitation approaches, we circumscribe two main clades referred to as the $D$. wrightii clade, with five unequivocal species, including $D$. gelida sp. nov., and the $D$. praetextata clade, with eight putative species, including $D$. phyllidiata sp. nov. The absence of recently collected material of $D$. hookeri comb. nov. from the type locality unfortunately prevents assignment of this epithet to one of the five supported lineages sharing this morphotype. Three new combinations are proposed: $D$. hookeri, $D$. insinuans comb. nov. and $D$. yatabeana comb. nov. Epitypes are designated for $D$. wrightii and $D$. yatabeana. Species diversity within the genus increased from four to nine. Our morphological assessment confirmed that Sticta and Dendriscosticta can be readily distinguished by the presence of excipular algae whereas the structure of the lower surface pores is not a reliable diagnostic feature.
\end{abstract}

Keywords Dendriscocaulon; epitypification; lichenized fungi; Lobariaceae; Lobarioideae; Peltigeraceae; Sticta

Supporting Information may be found online in the Supporting Information section at the end of the article.

\section{INTRODUCTION}

Lichens comprise approximately one-fifth of known fungal diversity, with almost 20,000 species of lichen-forming fungi currently recognized (Lücking \& al., 2017a). With more than 400 accepted species, the former Lobariaceae compose one of the largest families of lichenized fungi (Peltigerales, Ascomycota; Kirk \& al., 2008; Lücking \& al., 2017a). However, recent phylogenetic analyses resulted in a reclassification of the Lobariaceae as Lobarioideae within the Peltigeraceae (Kraichak \& al., 2018; Lücking, 2019). Furthermore, its three long-established genera (i.e., Lobaria, Pseudocyphellaria and Sticta) were split in 13 genera based on a correlation between the phylogeny and phenotypes (Galloway \& Elix, 2013; Moncada \& al., 2013b; Cornejo \& Scheidegger, 2015; Galloway, 2015; Widhelm \& al., 2019; Simon \& al., 2020). In addition, multiple instances of semi-cryptic speciation were uncovered in many genera (Moncada \& al., 2014; Magain \& Sérusiaux, 2015; Lücking \& al., 2017b). Indeed, taxon concepts within Lobarioideae have changed dramatically with advances in molecular phylogenetics, matching similar instances of taxonomic overhaul across in a wide range of microlichens, such as the

Article history: Received: 30 Dec 2020 | returned for (first) revision: 5 Feb 2021 | (last) revision received: 25 Aug 2021 | accepted: 2 Sep 2021 Associate Editor: Alain Vanderpoorten | (C) 2021 International Association for Plant Taxonomy. 
Graphidaceae (Rivas Plata \& al., 2013) and Trypetheliaceae (Lücking \& al., 2016), or numerous genera of macrolichens, such as Peltigera (Magain \& al., 2017, 2018) and Cora (Lücking \& al., 2014).

The genus Sticta (Schreb.) Ach. has historically been diagnosed by the presence of rimmed crater-like cavities (named cyphellae) on the lower surface (e.g., Yoshimura \& Hurutani, 1987). This trait is now considered homoplasious, defining a polyphyletic grouping, with the $S$. wrightii group composing a distinct clade, for which the genus Dendriscosticta Moncada \& Lücking was introduced (Moncada \& al., 2013b). The placement of Dendriscosticta in the Lobaria s.l. clade, separate from Sticta s.str., was confirmed by phylogenomic inferences (Widhelm \& al., 2019), based on 400 single-copy nuclear genes. While Sticta and Dendriscosticta both develop welldelimited pores on the lower surface, the genuine cyphellae in Sticta generally have noticeable overarching margins, whereas the cyphelloid pores in Dendriscosticta tend to have less pronounced borders (Moncada \& al., 2013b). These two genera further differ in the absence of excipular algae in Sticta versus their presence in Dendriscosticta (Takahashi \& al., 2006).

Some species of both genera have the capacity to associate with either a green alga or a cyanobacterium as their main photosynthetic partner, and the resulting photomorphs can either grow independently or form composite thalli (e.g., Armaleo \& Clerc, 1991; Tønsberg \& Goward, 2001; Magain \& al., 2012; Moncada \& al., 2013a). Within Dendriscosticta, photomorphs are always dimorphic: the chloromorph (mycobiont primarily associated with a green alga) is green and foliose, whereas the cyanomorph (mycobiont primarily associated with a cyanobacterium) forms a dark bluish, fruticose thallus. This morphology is also found in early diverging clades in Sticta s.str., including species such as $S$. filix and S. latifrons (Ranft \& al., 2018). Historically, the fruticose cyanomorphs, which also occur in other lobarioid genera such as Ricasolia (e.g., Jørgensen, 1996), were accommodated in the genus Dendriscocaulon (Nylander, 1885; Galloway, 1983; Jørgensen, 1998; Galloway, 2001). However, the advent of DNA sequencing revealed that this taxon was polyphyletic and composed of species also lichenized with green algae, and accommodated in other genera (Högnabba \& al., 2009; Magain \& al., 2012; Moncada \& al., 2013b).

Dendriscosticta is a characteristic and conspicuous component of old-growth rainforests with good air quality in the Northern Hemisphere and is often considered a flagship group of high conservation priority in montane subtropical and temperate/boreal biomes (e.g., Goward, 1994; Goward \& Arsenault, 2000; Karasev \& Selivanov, 2014; Devkota \& al., 2017). Ongoing rapid loss of these rainforests at a global scale (Xu \& Liu, 1996; DellaSala, 2011) is an important contributor to the Holocene extinction (Kolbert, 2014; Pimm \& al., 2014; Ceballos \& al., 2015; Ceballos \& Ehrlich, 2018; Shrimpton, 2019), threatening the survival of many taxa before they can be adequately studied or even named, and hence precluding efficient conservation efforts (Thomson \& al., 2018). Despite their high conservation relevance and documented ethnobotanical uses (Ding, 2010; Wang \& Qian, 2013), species of Dendriscosticta are in need of taxonomic revision, given the studies by Takahashi (2006) and Moncada \& al. (2013b), which suggested that presumably widespread taxa such as D. wrightii likely represent multiple species.

Here, we undertake a thorough taxonomic revision of the genus Dendriscosticta across its entire global range, encompassing three main objectives: (1) assess its evolutionary history and diversity; (2) define species boundaries using an integrative taxonomic framework, including sequence-based species delimitation approaches; and (3) evaluate and stabilize the nomenclature of its species.

\section{MATERIALS AND METHODS}

Taxon sampling. - Fresh material of Dendriscosticta was collected in Canada (British Columbia), China (Sichuan, Xizang, Yunnan), India, Japan (Hokkaido, Honshu), Russia (Komi Republic, Krasnoyarsk Krai), Taiwan, and the U.S.A. (Alaska, Minnesota). Based on earlier phylogenetic studies by Moncada \& al. (2013b) and Widhelm \& al. (2019), we chose as outgroups Ricasolia quercizans (Michx.) Stizenb. and $R$. virens (With.) H.H.Blom \& Tønsberg, and gathered sequence data for a total of 234 specimens of Dendriscosticta (including "Dendriscocaulon"; Appendix 1). Type specimens were provided by FH (Farlow Herbarium, Harvard University, U.S.A.), G (Geneva Herbarium, Conservatoire et Jardin botaniques de la Ville de Genève, Switzerland), H (Finnish Museum of Natural History, University of Helsinki, Finland) and US (Smithsonian Institution, Washington, D.C., U.S.A.). Newly collected specimens were deposited at ALTA (University of Alberta, Canada), CONN (University of Connecticut, U.S.A.), KoLRI (Korean Lichen Research Institute, South Korea), KUN (Kunming Institute of Botany), LG (University of Liège, Belgium), TNS (National Museum of Nature and Science, Japan), and UBC (University of British Columbia, Canada).

Morphological, anatomical and chemical characters. Specimens were studied at the University of Liège (Belgium), the University of Connecticut (Storrs, Connecticut, U.S.A.), and the Kunming Institute of Botany (China), using standard microscopic techniques. Morphological descriptions are based on observations using an Olympus (Olympus, Tokyo, Japan) SZ60 dissecting microscope, and an Olympus BX53 compound microscope. Anatomical sections through cyphellae and cyphelloid pores in Dendriscosticta and Sticta were examined in lactophenol cotton blue (LPCB). In addition, scanning electron microscopy (SEM) was carried out on selected specimens in order to highlight lobe ultrastructure (namely cortex and pores). Dry thalli were gold sputter-coated with approximately $10 \mathrm{~nm}$ of gold and affixed to aluminum plates using an FEI XL-30 scanning electron microscope (Field Electron and Ion Company, Hillsboro, Oregon, U.S.A.). Descriptive terminology followed the standardized approach used by Moncada $\&$ al. (2014) for the genus Sticta. Thin-layer chromatography (TLC) was carried out for selected specimens following Orange $\&$ al. (2001). Detailed descriptions are provided for the newly 
described species (D. gelida, D. phyllidiata), the epitypified species (D. wrightii, D. yatabeana comb. nov.) and one new combination (D. insinuans). For all other species, we provide short descriptions. For the comparison of cyphelloid pores in Dendriscosticta and genuine cyphellae in Sticta, we chose two representatives of Dendriscosticta and seven species of Sticta that were included in Widhelm \& al. (2018).

DNA extraction, PCR amplification and sequencing. Genomic DNA was isolated from well-preserved specimens following the protocol by Cubero \& al. (1999) or using Nucleospin Plant II Midi kits (Macherey-Nagel, Bethlehem, Pennsylvania, U.S.A.) following the manufacturer's guidelines. The nuclear internal transcribed spacer (ITS) region was amplified via polymerase chain reaction (PCR) for 218 specimens, using the primers ITS1F (Gardes \& Bruns, 1993) and ITS4 (White $\&$ al., 1990). From these we selected 82 specimens that represented a distinct ITS haplotype from the main geographical areas from which fresh material was obtained. Three additional, nuclear fungal markers were amplified for most specimens in this subset: (1) a portion of the RNA polymerase II largest subunit $(R P B 1),(2)$ a portion of the translation elongation factor-1 alpha gene $(E F-1 \alpha),(3)$ and a portion of the DNA replication licensing factor (MCM7). The PCR conditions were as follows: denaturation at $94^{\circ} \mathrm{C}$ for $3 \mathrm{~min}$; followed by 40 cycles with denaturation at $94^{\circ} \mathrm{C}$ for $1 \mathrm{~min}$, annealing at $51^{\circ} \mathrm{C}-55^{\circ} \mathrm{C}$ for $1 \mathrm{~min}$, and extension at $70^{\circ} \mathrm{C}$ for $1 \mathrm{~min}$; followed by a final extension at $70^{\circ} \mathrm{C}$ for $10 \mathrm{~min}$. PCR annealing temperatures and primers are detailed in Table 1 . The quality and size of the amplicons were checked by visual inspection on a $1 \% \mathrm{w} / \mathrm{v}$ agarose gel stained by SYBR Safe DNA Gel Stain (Thermo Fisher Scientific, Waltham, Massachusetts, U.S.A.). PCR products that yielded high-quality bands in agarose gel electrophoresis were purified using ExoSAP (Affymetrix, Santa Clara, California, U.S.A.). Amplicons were sequenced by Macrogen (Seoul, South Korea) using amplification primers. Sequences were edited using Sequencher v.4.9 (Gene Codes, Ann Arbor, Michigan, U.S.A.) or Geneious v.10.0.7 (Biomatters, Auckland, New Zealand) and subjected to BLAST searches (Altschul \& al., 1990) in GenBank to detect potential contaminations. All newly generated sequences were deposited in GenBank (Appendix 1).
Molecular phylogenetic analyses. - Three datasets were analyzed for this study: (1) a single-locus ITS dataset for the Dendriscosticta wrightii clade comprising a selection of 126 specimens, including 11 sequences retrieved from GenBank; (2) a single-locus ITS dataset for the $D$. praetextata clade comprising a selection of 108 specimens, including 6 sequences retrieved from GenBank; and (3) a 4-locus dataset comprising a selection of 82 specimens, representing the genetic and geographical diversity of the entire genus, with Ricasolia quercizans and $R$. virens selected as composing a monophyletic outgroup.

Alignments for each gene and dataset were assembled in Geneious v.10.0.7 (Biomatters, Auckland, New Zealand) using the MAFFT plugin v.1.4.0 run in auto mode (Katoh, 2002; Katoh $\&$ al., 2009), and the ends of each alignment were trimmed. The ITS matrix of the 4-locus dataset was realigned using default MAFFT v.6.861b settings, with two alignment iterations, as implemented in GUIDANCE v.2.01 (Penn \& al., 2010). Sites with low-quality scores (i.e., with confidence scores below 0.93) were excluded from the matrix, which resulted in an alignment of $480 \mathrm{bp}$ (initially $638 \mathrm{bp}$ ). The three proteincoding genes were analyzed with all sites included. Since the single-locus ITS matrices contained relatively few ambiguous portions, the two matrices were analyzed with all sites included (Dendriscosticta praetextata clade: 612 bp; D. wrightii clade: $617 \mathrm{bp})$.

We performed a maximum likelihood (ML) analysis on the two single-locus ITS datasets using RAxML-HPC2 v.8.2.3 (Stamatakis, 2014) on the CIPRES portal (Miller \& al., 2010; https://www.phylo.org), using the rapid hill-climbing algorithm and bootstrapping with 1000 pseudoreplicates under a GTR $+\Gamma$ model of evolution. As for the 4-locus dataset, prior to concatenation, single-locus phylogenetic trees were produced for each marker via RAxML-HPC2 v.8.2.3 on the CIPRES portal with the same parameters as described above. Compatibility between trees was checked by testing for conflicts among wellsupported clades using the program compat.py v.3.0 (Kauff \& Lutzoni, 2002, 2003) and an $80 \%$ bootstrap cut-off value for supported incompatibilities. We detected no significant conflict with support values $\geq 80 \%$ among putative species. Therefore,

Table 1. Polymerase chain reaction primers and annealing temperatures used for the amplification of the nuclear internal transcribed spacer region ITS, the RNA polymerase II largest subunit $(R P B 1)$, the translation elongation factor-1 alpha gene (EF1- $\alpha$ ), and the DNA replication licensing factor $(M C M 7)$.

\begin{tabular}{lllll}
\hline Locus & Primer name & Primer sequence $\left(5^{\prime} \rightarrow 3^{\prime}\right)$ & $\begin{array}{l}\text { Annealing } \\
\text { temperature }\left({ }^{\circ} \mathrm{C}\right)\end{array}$ & Reference \\
\hline ITS & ITS1F & CTTGGTCATTTAGAGGAAGTAA & $51-52$ & Gardes \& Bruns, 1993 \\
& ITS4 & TCCTCCGCTTATTGATATGC & White \& al., 1990 \\
RPB1 & RPB1_LobF2 & CATATGGGYTTGGCTGATC & This study \\
& RPB1_LobR2 & CCWGACTTCTGCAARGCTT & 54 & This study \\
EF-1 $\alpha$ & EF_LobF & TCTTTCAAATAYGCMTGGGT & 54 & This study \\
& EF_LobR & TCCTGGAGRGGRAGACGSA & & This study \\
\multirow{2}{*}{$M C M 7$} & MCM7_DendriF & AAGCCATCGGTGCAGGTAAA & 55 & This study \\
& MCM7_DendriR & CGATTTAGCCACACCAGGGT & & This study \\
\hline
\end{tabular}


the sequences of the four loci were concatenated in a single dataset for subsequent analyses.

The concatenated alignment consisted of 2521 positions (ITS: 480 bp; RPB1: 779 bp; EF-1 1 : 598 bp; MCM7: 664 bp). PartitionFinder v.2 (Lanfear \& al., 2016) was used to choose the best partitioning schemes and nucleotide substitution models for the subsequent maximum likelihood (ML) analysis. Ten initial subsets were considered (ITS, RPB1 1st, 2nd, 3rd codon positions, $E F-1 \alpha 1$ st, 2 nd, 3rd codon positions, $M c m 7$ 1st, 2 nd, 3 rd codon positions), and the default configuration settings were used (branchlengths $=$ linked, models $=$ all, model_selection $=$ BIC) with the greedy algorithm (Lanfear \& al., 2012). The GTR $+\Gamma$ model was the only one allowed. An ML analysis was performed on the 4-locus matrix dataset using RAxML v.8.2.3 on the CIPRES portal using the rapid hill-climbing algorithm and bootstrapping with 1000 pseudoreplicates under a GTR $+\Gamma$ model of substitutions for each matrix or each partitioned subset (subset 1: ITS; subset 2: RPB1 1st, 2nd codon positions, EF-1 $\alpha$ 1st, 2nd codon positions, $M C M 7$ 1st, 2nd codon positions; subset 3: RPB1 3rd codon positions, $E F-1 \alpha$ 3rd codon positions, $M C M 7$ 3rd codon positions). The resulting ML trees were visualized with the R package ggtree (Yu \& al., 2017). Alignments and resulting trees are available in TreeBASE (http://purl.org/ phylo/treebase/phylows/study/TB2:S26492).

Species delimitation and species-tree inference. Species delimitation was inferred from a combination of morphological, chemical and molecular data. Three sequencebased species delimitation methods were used and are detailed hereafter.

First, we used the species delimitation method Automatic Barcode Gap Discover (ABGD; Puillandre \& al., 2012), which splits sequences into groups reflecting candidate species based on gaps between intra- and interspecific diversity of genetic barcodes. The analysis was carried out on the ITS matrix for the 82 samples included in the 4-gene dataset using the online server https://bioinfo.mnhn.fr/abi/public/abgd/ (last accessed Nov 2020). Genetic distances between samples were estimated using the JC69 nucleotide substitution model (Jukes \& Cantor, 1969), and considering a relative gap width value of 0.5. The ABGD analyses were carried out on the Dendriscosticta praetextata and D. wrightii clades separately. Ultimately, the following partitions were selected: 13 groups within the $D$. praetextata clade $(P=4.64 \mathrm{e}-03)$ and eight groups within the $D$. wrightii clade $(P=3.73 \mathrm{e}-03)$.

Second, we used the general mixed Yule coalescent (GMYC) model (Pons \& al., 2006; Fujisawa \& Barraclough, 2013) for delimiting species based on a single locus. As this method requires an ultrametric single-locus gene tree as input, we analyzed the ITS region marker extracted from the 4-gene dataset using BEAST v.2.4.8 (Bouckaert \& al., 2014). We ran the analysis using a TrNef+I substitution model (see below), with a strict clock model and a Yule model (Yule, 1924), for 20 million generations, sampling parameters every 500th generation. We used the topology of the 4-locus tree generated in the abovementioned ML analysis as input tree and held this topology constant. The analysis was performed on the CIPRES Science
Gateway. Convergence of parameters was assessed using Tracer v.1.6 (Rambaut \& Drummond, 2013; Rambaut \& al., 2018). A burn-in of $20 \%$ was removed, and a maximum credibility tree with a cut-off of 0.5 of posterior probabilities was generated in TreeAnnotator v.2.4.8 (BEAST package). The GMYC analysis was carried out on the resulting tree using the web server of the Exelixis Lab (https://species.h-its.org/gmyc/; last accessed Nov 2020) and the single threshold method.

Third, species delimitation was further assessed using the Bayesian phylogenetics and phylogeography method (BP\&P v.3.3; Rannala \& Yang, 2003; Yang \& Rannala, 2010). As the number of species estimated by ABGD appeared relatively high, compared to morphological and chemical variation, we decided to use these entities as the input candidate species for the BP\&P analysis. In a few cases, the ABGD delimitation was incongruent with the tree topology derived from the concatenated loci. Several input groups were therefore further divided since the program is only able to regroup several predefined candidate species into more inclusive species but cannot divide these input species (suppl. Table S1). The multi-locus coalescent-based BP\&P analyses were performed using the abovementioned 4-gene ML tree as guide tree. The divergence time parameter tau $(\tau)$ was set to $G(2,38)$, corresponding to distribution means of 0.053 . The population size parameter theta $(\theta)$ prior was tested for different values: $G$ $(4,1000), G(8,1000)$, and $G(12,1000)$. The matrix was analyzed without the outgroup (i.e., $R$. quercizans and $R$. virens), using the reversible-jump Markov chain Monte Carlo (rjMCMC) algorithms implemented in the program BP\&P, sampling every generation for a total 5 million generations, with a burn-in period of 500,000 . A posterior mean of 0.5 was used as the probability cut-off, above which input groups are considered heterospecific.

We also inferred a species tree using the coalescent-based Bayesian model *BEAST (Heled \& Drummond, 2010), as implemented in BEAST v.2.4.8 (Bouckaert \& al., 2014). The inference of a species tree ideally requires the inclusion of several samples per delimited species (Camargo \& al., 2012). For this reason, we selected 74 individuals included in the 4-locus dataset, which were assigned to 12 candidate species groups (with at least two representatives per species) in agreement with the results of the BP\&P delimitation analysis (suppl. Table S1). The 4-gene dataset was prepared in BEAUti v.2.4.8 (BEAST package) and partitioned by locus. Substitution, clock and tree models were unlinked and the model of nucleotide substitution was selected based on the Bayesian information criterion (Schwarz, 1978) in jModelTest v.2.1.6 (Darriba \& al., 2012) on the CIPRES Science Gateway (ITS: TrNef+I; RPB1: $\mathrm{K} 80+\Gamma$; $E F 1-\alpha: \mathrm{K} 80+\Gamma ; M C M 7: \mathrm{K} 80+\Gamma)$. We first carried out a preliminary analysis using a relaxed, lognormal, uncorrelated clock: this run supported a clock-like rate of evolution, as the standard deviation estimate of the clock was close to zero. For this reason, we used a strict clock model in the final analysis. We also employed a Yule model (Yule, 1924) and the substitution rate for $R P B 1\left(1.73 \times 10^{-3} \mathrm{~s}^{-1} \mathrm{myr}^{-1}\right)$ as secondary calibration (derived from the substitution rates within Melanelixia; Leavitt 
$\&$ al., 2012). The *BEAST analysis was run for 100 million generations, sampling parameters every 5000th generation, and performed on the CIPRES Science Gateway. Convergence, mixing, and effective sample sizes (ESS) of parameters were checked in Tracer v.1.6 (Rambaut \& al., 2013). All the ESS values were larger than 200 . A burn-in of $20 \%$ was removed, and a maximum credibility tree with a cut-off of 0.5 of posterior probabilities was generated with the remaining 16,000 trees in TreeAnnotator v.2.4.8 (BEAST package) and visualized with the R package ggtree (Yu \& al., 2017). In addition, the 16,000 sampled posterior trees were visualized using DensiTree v.2.2.6 (Bouckaert \& Heled, 2014).

Molecular barcoding approach. - Short ITS2 barcode sequences (ranging from 29 to $33 \mathrm{bp}$ ) were designed for most species of Dendriscosticta here recognized, given the lack of phenotypic characters diagnosing several taxa (see key, below). The reliability of DNA barcodes was evaluated using the query sequences in GenBank for the species encompassed in the $D$. wrightii clade. For this approach, we used the BLASTn algorithm (Altschul \& al., 1990, 1997) and the default settings optimized for a short input sequence (word size $=7$; match/ mismatch scores $=1 /-3$; gap costs $=$ existence: 5 , extension:
2). In order to assess the efficiency of the designed barcodes, BLASTn top-scoring hits were ranked by E-value and compared to the species identities inferred from the formerly mentioned phylogenetic inferences. This evaluation was made possible by the inclusion of most GenBank accessions falling in the genus Dendriscosticta (suppl. Table S1). Ultimately, corrected reference sequence identifications were proposed for previous GenBank accessions following the strategy used by Lücking $\&$ al. (2020b).

\section{RESULTS}

Morphological and chemotypic diversity. - Four typical and well-delimited morphotypes were detected within Dendriscosticta, and their main features are as follows (Fig. 1):

(1) Foliose thalli primarily associated with a green alga (chloromorph), with lobe apices usually curled upwards (involute) and upper surface having a pruinose appearance (Figs. 1A, 2B);

(2) Foliose thalli primarily associated with a green alga (chloromorph) with lobe apices usually curled
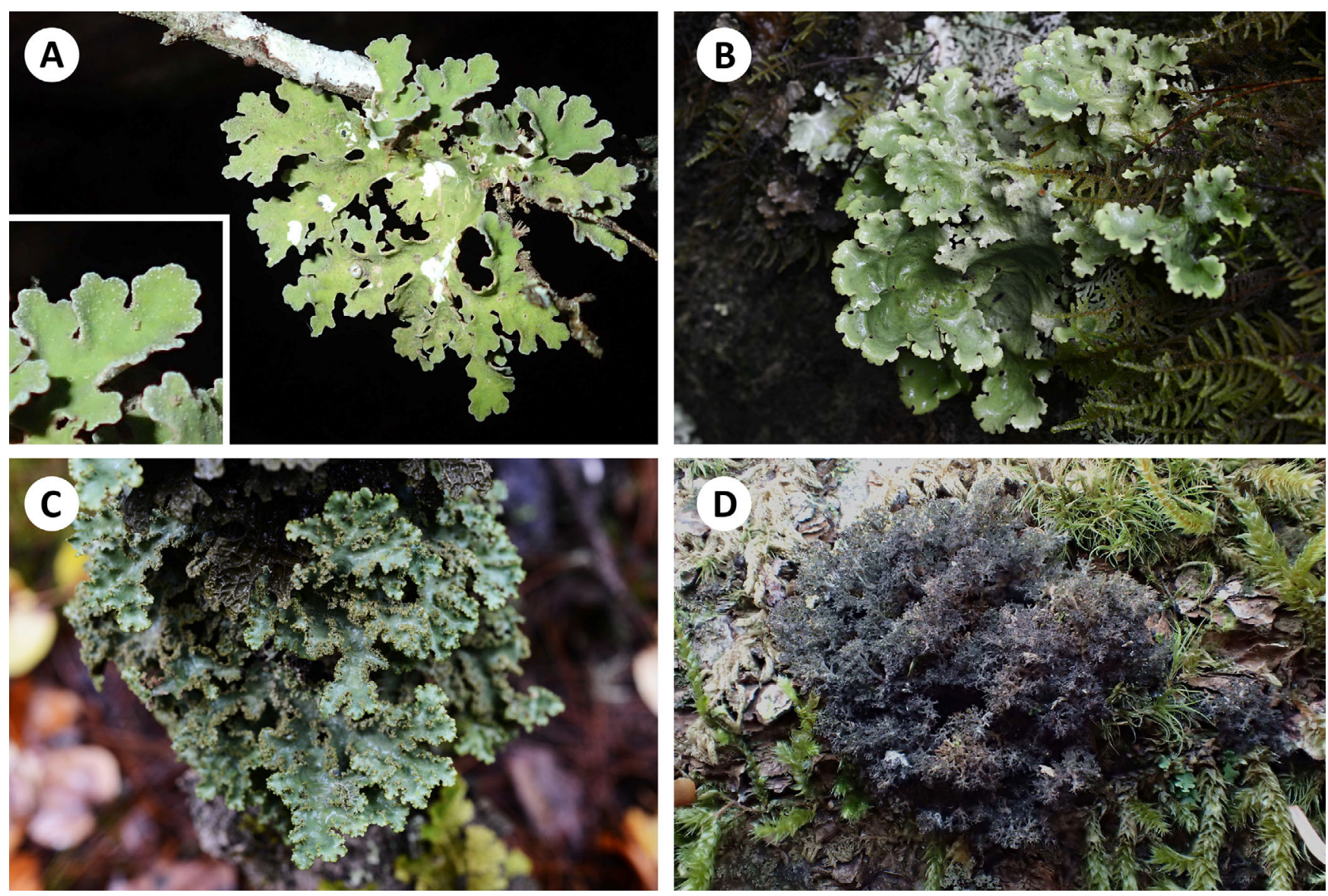

Fig. 1. The four easily distinguishable morphotypes in Dendriscosticta. A, D. gelida (field image from British Columbia), showing a foliose thallus with involute, seemingly pruinose lobes due to hyphae protruding from the cortex; B, D. aff. hookeri 2 (Wang 16-52068, KUN), showing a foliose thallus with revolute, smooth lobes; C, D. praetextata (Wang 16-52037, KUN), showing a foliose thallus with numerous phyllidia; D, Cyanomorph of D. gelida (Simon 458, LG), showing a dark, fruticose thallus. Photographs by A. Simon (A, D) and L.S. Wang (B, C). 
downwards (revolute) and upper surface smooth or glossy (Figs. 1B, 2C);

(3) Foliose thalli primarily associated with a green alga (chloromorph), with lobes bearing numerous phyllidia and upper surface smooth (Fig. 1C);

(4) Fruticose thalli (dendriscocauloid) primarily associated with a cyanobacterium (cyanomorph), forming arbusculoid, bush-like structures with terete or slightly flattened branches, with convoluted or irregular surface (Figs. 1D, 2A).

Thin-layer chromatography was carried out on all specimens included in the 4-locus dataset (suppl. Table S1; Fig. 3). Three major compounds were distinguished in the material studied: the depside pseudocyphellarin A (Elix \& Lajide, 1984), and two well-known depsides that are commonly detected in lichenized fungi, gyrophoric and congyrophoric acids (Elix, 2014).

A comparison of the anatomy of the cyphelloid pores assumed to be diagnostic for Dendriscosticta (Moncada $\&$ al., 2013b) and of genuine cyphellae in Sticta revealed that the crater-like subcircular depressions on the lower surface vary in abundance, size, and the shape of the rim (varying from low rims with gentle slope to abrupt rims bending towards the center of the cyphellae), and that the variation of these traits is much greater within Sticta (Fig. 4). A focused
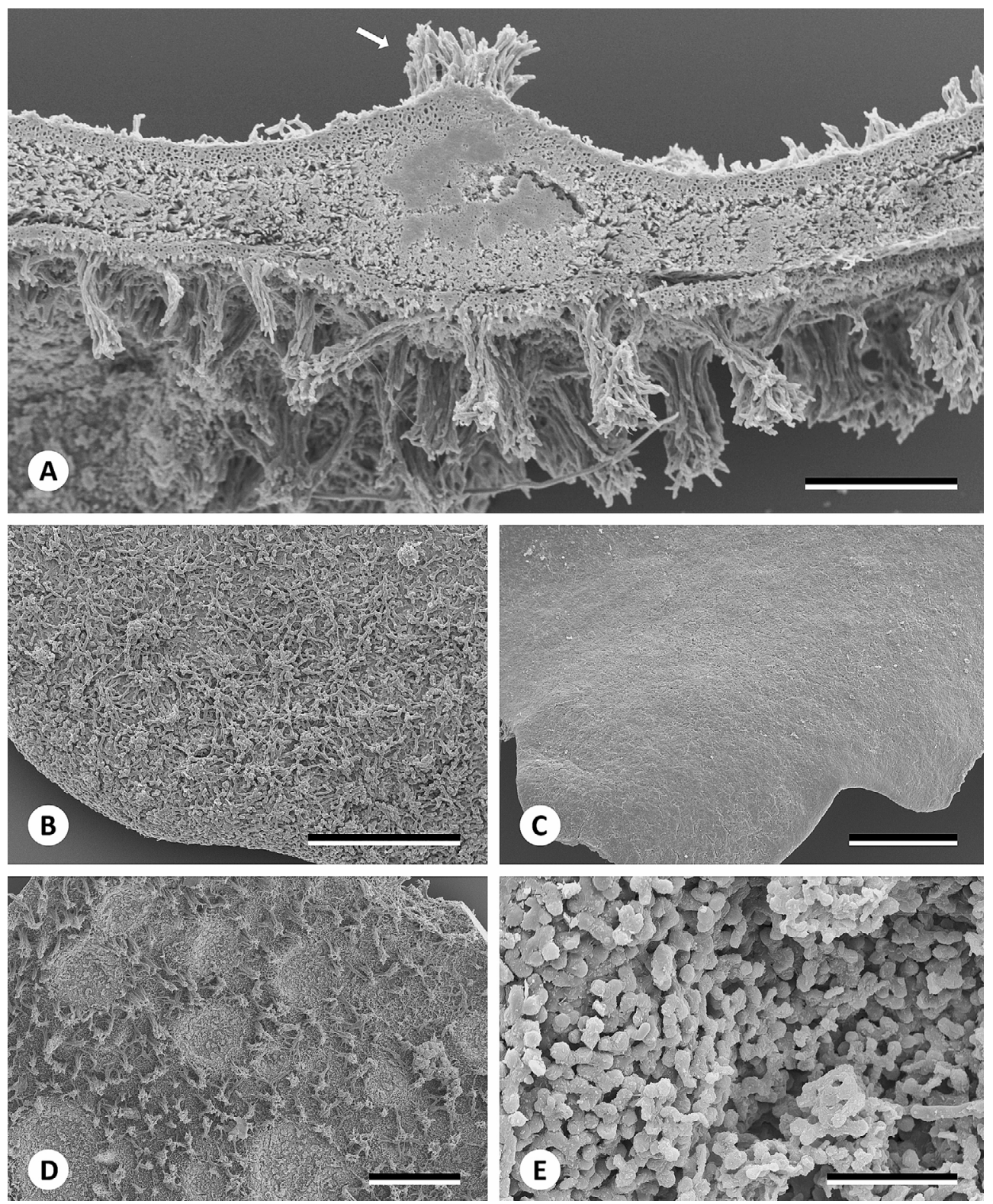

Fig. 2. Scanning electron microscopy pictures of Dendriscosticta species. A, Transversal section through D. oroborealis (Goffinet 10010, CONN), showing an early dendriscocauloid thallus (arrow) emerging from an internal cephalodium in a foliose, chloromorphic thallus; B, D. oroborealis (Spribille s.n.), showing the upper surface of a seemingly pruinose lobe with hyphae protruding from the cortex; C, D. aff. hookeri (Spribille 23667), showing the upper surface of a smooth lobe; D, D. oroborealis (Goffinet 10010, CONN), showing lower surface with cyphelloid pores; E, D. oroborealis (Spribille s.n.) showing a close-up of a cyphelloid pore with angular, dumbbell-like cells. — Scales: A $=200 \mu \mathrm{m}, \mathrm{B}-\mathrm{D}=500 \mu \mathrm{m}, \mathrm{E}=50 \mu \mathrm{m}$. 


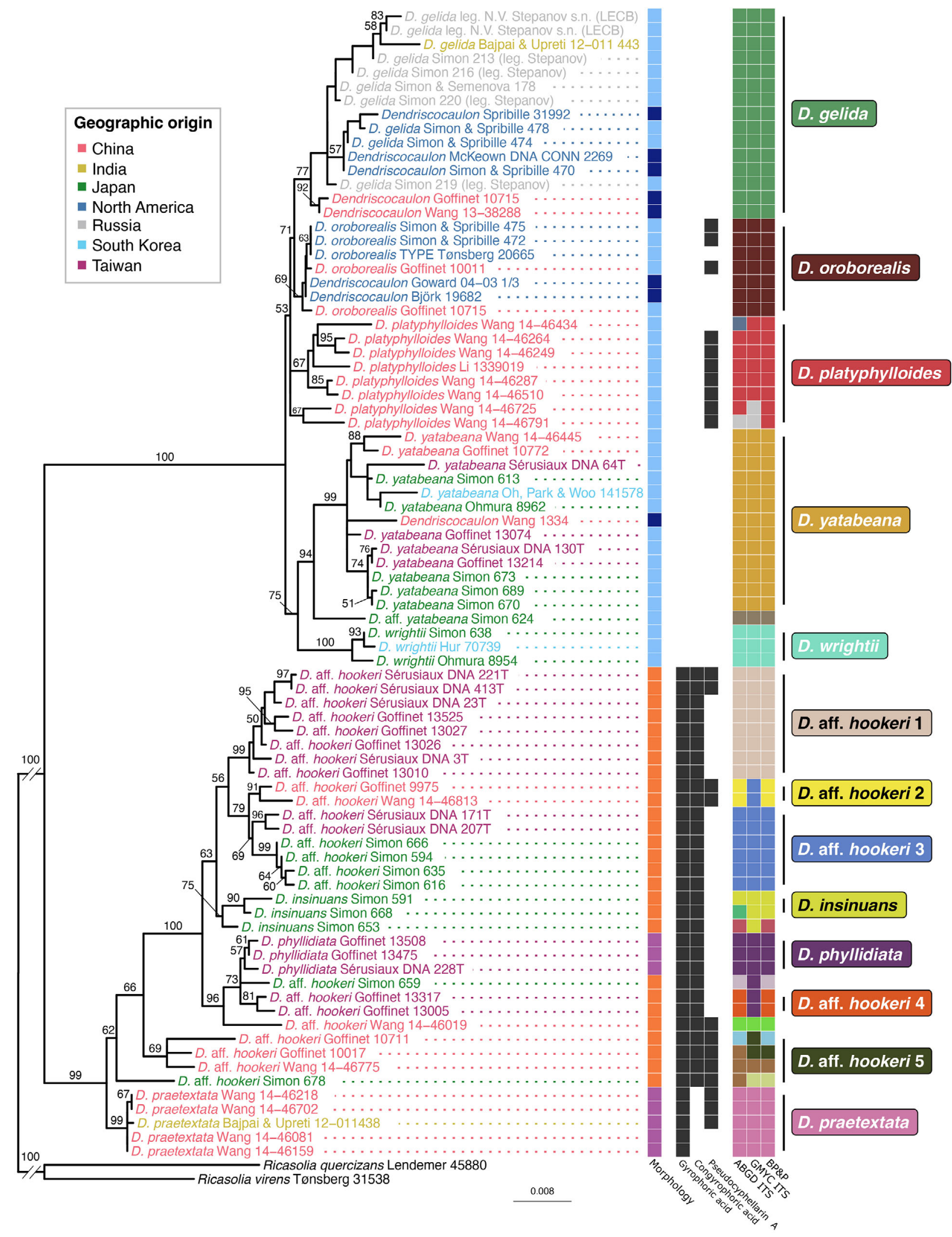

Fig. 3. Single most likely phylogenetic tree of the genus Dendriscosticta obtained from inferences of four-locus molecular data (ITS, RPB1, EF1- $\alpha$, $M C M 7$ ), with morphotypes (column 1: dark blue, dendriscocauloid; light blue, foliose and seemingly pruinose; orange, foliose and smooth; purple, phyllidiate), chemical assessments (columns 2-4), sequence-based species delimitation (columns 5-7: ABGD, GMYC, BP\&P with $\theta=\mathrm{G}$ $[4,1000]$ ). Values above branches represent ML bootstrap values (indicated when $\geq 50$ ). Colors in the taxa names refer to the origin of the samples. Original identifications found in GenBank were retained. The cross-hatched branches have been shortened to one tenth. 
screening of the basal membrane of the cyphelloid pores and cyphellae, revealed further variation and differences between taxa. In Dendriscosticta, the membrane is a c. $20 \mu \mathrm{m}$ thick layer of intermingled, irregularly branched but with almost perpendicular branching usually dominant, and slightly but distinctly inflated hyphae (Figs. 2D,E, 4A,B). The membrane of the cyphellae of Sticta stipitata C.Knight and S. cyphellulata (Müll.Arg.) Hue is also about $20 \mu \mathrm{m}$ thick, but the cells are more globose (Fig. 4C,D). In S. canariensis (Bory) Delise, the layer is slightly thicker, i.e., $25-30 \mu \mathrm{m}$, and all cells forming the cyphellae membrane are globose (Fig. 4E). In S. ciliata Tayl. and S. fuliginoides Magain \& Sérus., two cell layers can be distinguished: a lower one, with one or two typically ovoid cells with irregular shape (5-10 $\mu \mathrm{m}$ in diameter) and an upper one composed of smaller papillose cells $(5-8 \mu \mathrm{m}$ in diameter; Fig. 4F,G). In S. fuliginosa (Dicks.) Ach., the floor is composed of two or three layers of irregularly ovoid to typically globose cells (Fig. 4H). In S. sylvatica (Huds.) Ach., a basal layer of large globose cells $(8-15 \mu \mathrm{m}$ in diameter) is easily distinguished from the upper layer of smaller $(5-8 \mu \mathrm{m})$ globose cells (Fig. 4I). In summary, the membrane seems to be mainly hyphal (with densely arranged hyphae leaving some interspaces) in Dendriscosticta, whereas in Sticta it appears to be more compact and a paraplectenchymatous membrane floor is clearly perceptible in most cases. While the assumed way of separating Dendriscosticta from Sticta based on lower surface pores (Moncada $\&$ al., 2013b) did not hold in every case, we conversly confirmed that the presence of algae in the excipular tissue of
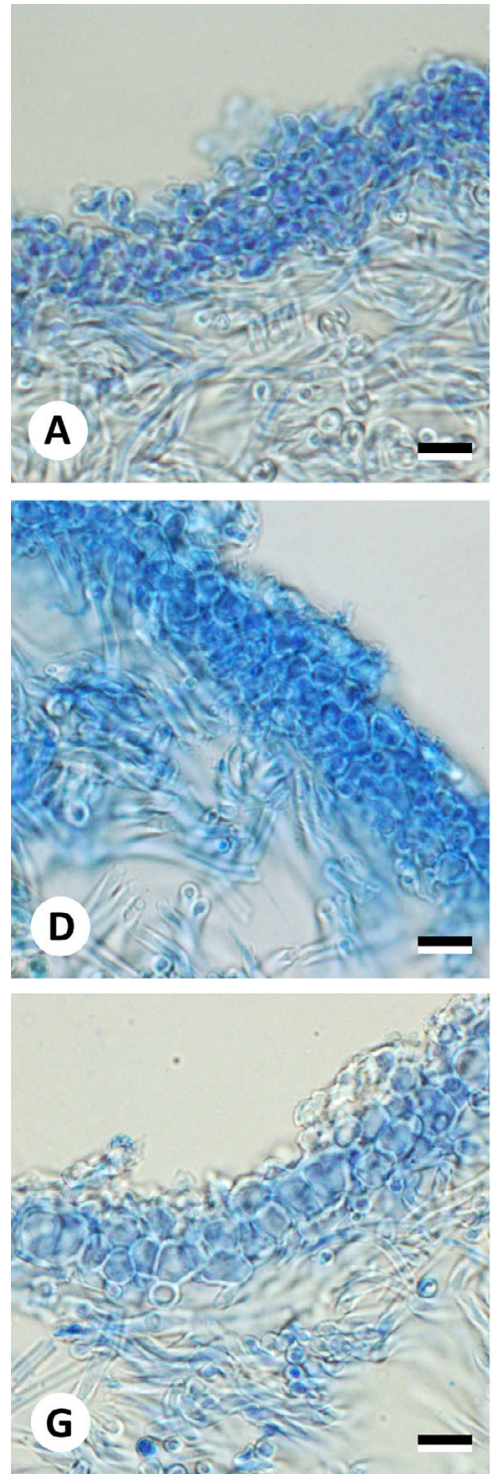
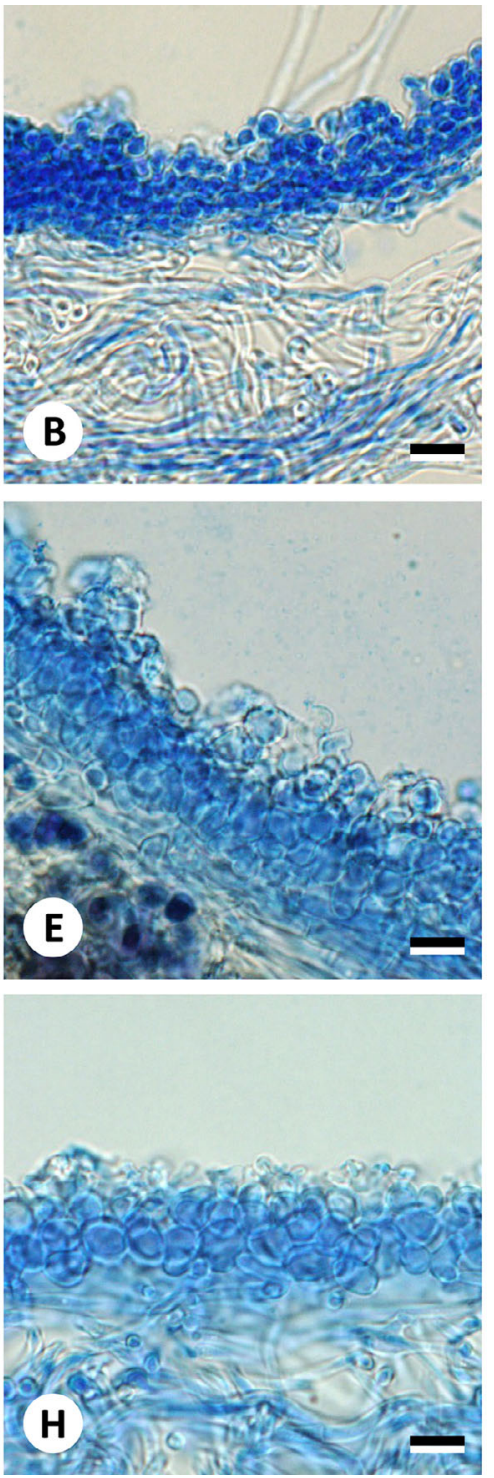
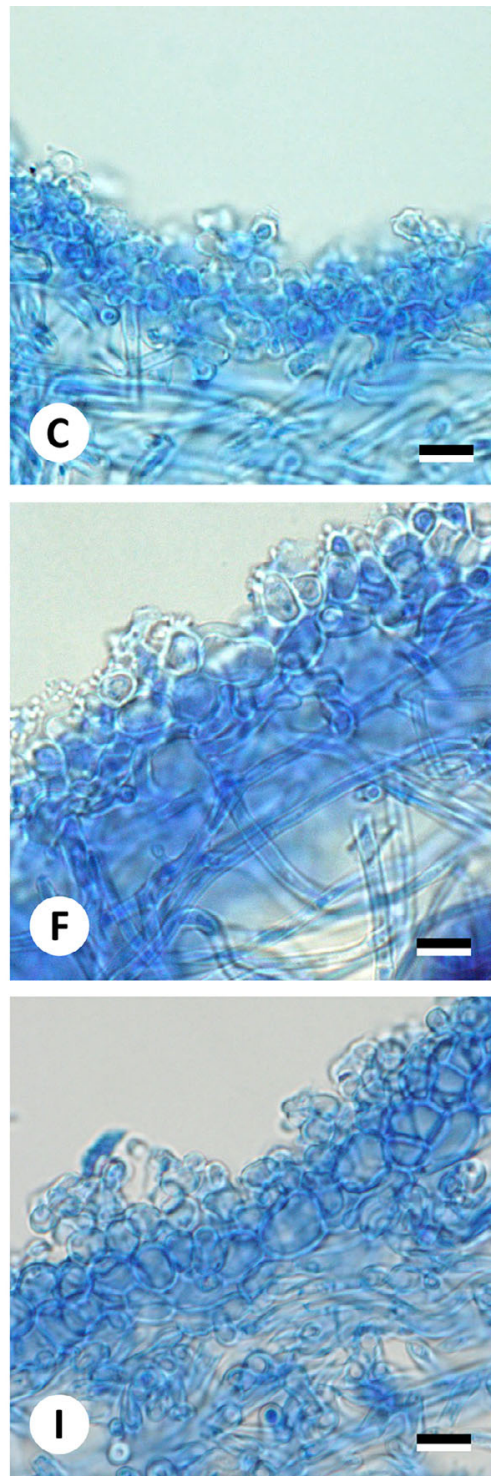

Fig. 4. Transversal sections of cyphellae and cyphelloid pores, stained with lactophenol cotton blue, in various species of Dendriscosticta. A, D. gelida (Simon 463, LG); B, D. aff. hookeri (Simon 653, LG); C, Sticta stipitata (Kantvilas 73/10, DNA LG 1253); D, S. cyphellulata (Sérusiaux s.n., DNA LG 1023); E, S. canariensis (Sérusiaux s.n., DNA LG 1333); F, S. ciliata (Sérusiaux s.n., DNA LG 3540); G, S. fuliginoides (Sérusiaux s.n., DNA LG 3391); H, S. fuliginosa (Sérusiaux s.n., DNA LG 901; I, S. sylvatica (Sérusiaux 7699, LG). — Scales = $10 \mu$ m. 
Dendriscosticta represents a reliable, diagnostic feature to distinguish the two genera.

Phylogenetic relationships. - Phylogenetic analysis of the 4-locus dataset resulted in two main clades within Dendriscosticta hereafter referred to as the D. praetextata and D. wrightii clades, both with high support values (Fig. 3; bootstrap support [BS]: 99 and 100, respectively). The D. wrightii clade can be tentatively divided in five main subclades (Figs. 3, 5): (1) a lineage (BS: ITS, 37; 4-locus, 77) with representatives occupying a wide range in the Holarctic realm, across boreal and temperate areas, seemingly lacking lichen substances, and including the morphotypes $\mathrm{A}$ and $\mathrm{D}$ (here accommodated in D. gelida sp. nov.); (2) a fairly well-supported lineage (BS: ITS, 83; 4-locus, 69) comprising the holotype of $D$. oroborealis and samples from western Canada (British Columbia) and southern China (Sichuan, Xinzang, Yunnan), with pseudocyphellarin A in some instances and including the morphotypes A and D (hereafter referred to as D. oroborealis); (3) a lineage (BS: ITS, 99; 4-locus, 38) with representatives restricted to the Chinese provinces of Xinzang and Yunnan, with pseudocyphellarin A in all but one specimen, and including the morphotypes A and D (hereafter referred to as D. platyphylloides); (4) a strongly supported lineage (BS: ITS, 93; 4-locus, 99) with representatives widely distributed in East Asia (China, Japan, South Korea, Taiwan), including the morphotypes A and B (hereafter referred to as D. yatabeana); (5) a small, strongly supported lineage (BS: ITS, 100; 4-locus, 100) with representatives restricted to Japan and South Korea, exhibiting the morphotype A (hereafter referred to as D. wrightii).

A sixth subclade, only comprising two specimens from Japan (BS: ITS, 100), is strongly resolved as sister to the Dendriscosticta yatabeana lineage in the 4-locus analysis (BS: $94)$ and was provisionally assigned to " $D$. aff. yatabeana" as it might represent one additional taxon owing to the long branch holding these specimens. All specimens within the D. wrightii clade share the presence of hyphal outgrowths on the lobe apices in chloromorphic individuals (morphotype A). The protruding hyphae account for the scabrose or pruinose appearance (Fig. 1A). The D. wrightii clade is also characterized by the absence of gyrophoric and congyrophoric acids. Cyanomorphic individuals (morphotype D) always lacked secondary metabolites. All taxa assigned to a supported species can be identified by a discrete diagnostic nucleotide sequence within ITS2 (Figs. 5, 6).

The Dendriscosticta praetextata clade can be tentatively divided in numerous subclades (Figs. 3, 7), most notably: (1) a lineage (BS: 4-locus, 99) with representatives restricted to Taiwan and exhibiting the morphotype B (hereafter referred to as D. aff. hookeri 1); (2) a lineage (BS: ITS, 36; 4-locus, 75) with representatives restricted to Japan and exhibiting the morphotype B (hereafter referred to as $D$. insinuans); (3) a weakly supported lineage (BS: 4-locus, 57) but with representatives having a well-defined distribution (Taiwan) and the unusual morphotype C (hereafter referred to as D. phyllidiata sp. nov.); (4) a poorly resolved assemblage (BS: ITS, 29) with representatives exhibiting morphotype B from Japan and southern China, with pseudocyphellarin A always detected (hereafter referred to as $D$. aff. hookeri 5); (5) a strongly supported lineage (BS: ITS, 96; 4-locus, 99) with representatives from southern China, always lacking congyrophoric acid, and exhibiting the morphotype C (identified as $D$. praetextata). Also, worth mentioning are the clades referred to as $D$. aff. hookeri 2-4, which received fairly strong support in the 4-locus analysis, further exemplifying the phylogenetic complexity of the $D$. praetextata clade. All specimens within the $D$. praetextata clade share a smooth upper surface (morphotypes B or C; Fig. 1B, C) and the presence of gyrophoric acid. Except for specimens of $D$. praetextata, congyrophoric acid is also always present. Cyanomorphic individuals (morphotype D) were not observed.

Molecular species delimitation. - The results of the different species delimitation analyses were projected onto the ML 4-locus phylogenetic tree (Fig. 3; suppl. Table S1). Species identifiers were assigned to the lineages delimited by the BP\&P approach (with $\theta=\mathrm{G}[4,1000]$ ), which included at least two representatives of each putative species. The identifier Dendriscosticta aff. hookeri 5, although not supported by the species delimitation methods, was also assigned to the set of mostly Chinese samples recovered as a monophyletic group in the ITS tree of the D. praetextata clade (Fig. 7).

The three analyses (ABGD, BP\&P, GMYC) yielded mostly consistent results, especially within the Dendriscosticta wrightii clade. In this clade, the different methods supported the recognition of five species $(D$. gelida, D. oroborealis, $D$. platyphylloides, $D$. wrightii, D. yatabeana) and potentially one more for a small clade (D. aff. yatabeana). The ABGD and GMYC analyses further divided $D$. platyphylloides in three and two entities, respectively. Within the D. praetextata clade, the three methods yielded consistent results for two cases (D. aff. hookeri $1, D$. praetextata) and contrasting delimitations for others. For example, $D$. aff. hookeri 2 and 3 were lumped in the GMYC analysis but distinguished in the ABGD and BP\&P analyses. Similarly, recognition of $D$. phyllidiata is supported and consistent among most analyses, with the exception of GMYC (merging this species and $D$. aff. hookeri 4 into a single entity). A few lineages were delimited differently depending on the prior used. For instance, the delimitation of $D$. insinuans was identical in the GMYC and BP\&P methods when a prior $\theta$ of $\mathrm{G}(8,1000)$ or $\mathrm{G}(12,1000)$ was applied to the latter (suppl. Table S1).

Coalescent-based species tree. - The *BEAST species tree (Fig. 8) is congruent with the ML topology estimated from the concatenated 4-locus alignment, except for Dendriscosticta insinuans, which is sister to the clade composed of $D$. aff. hookeri 4 and D. phyllidiata in the first analysis (posterior probability [PP]: 0.59), but sister to the group $D$. aff. hookeri 1-3 in the ML tree (BS: 63). The cloudogram (Fig. 8) highlights the uncertainty in some species relationships across the posterior distribution of species trees, especially within the $D$. praetextata clade. Divergence estimates from the coalescent-based species tree analysis suggest that the split between the two main clades, i.e., the $D$. praetextata and $D$. wrightii clades, occurred in the Miocene, approximately 


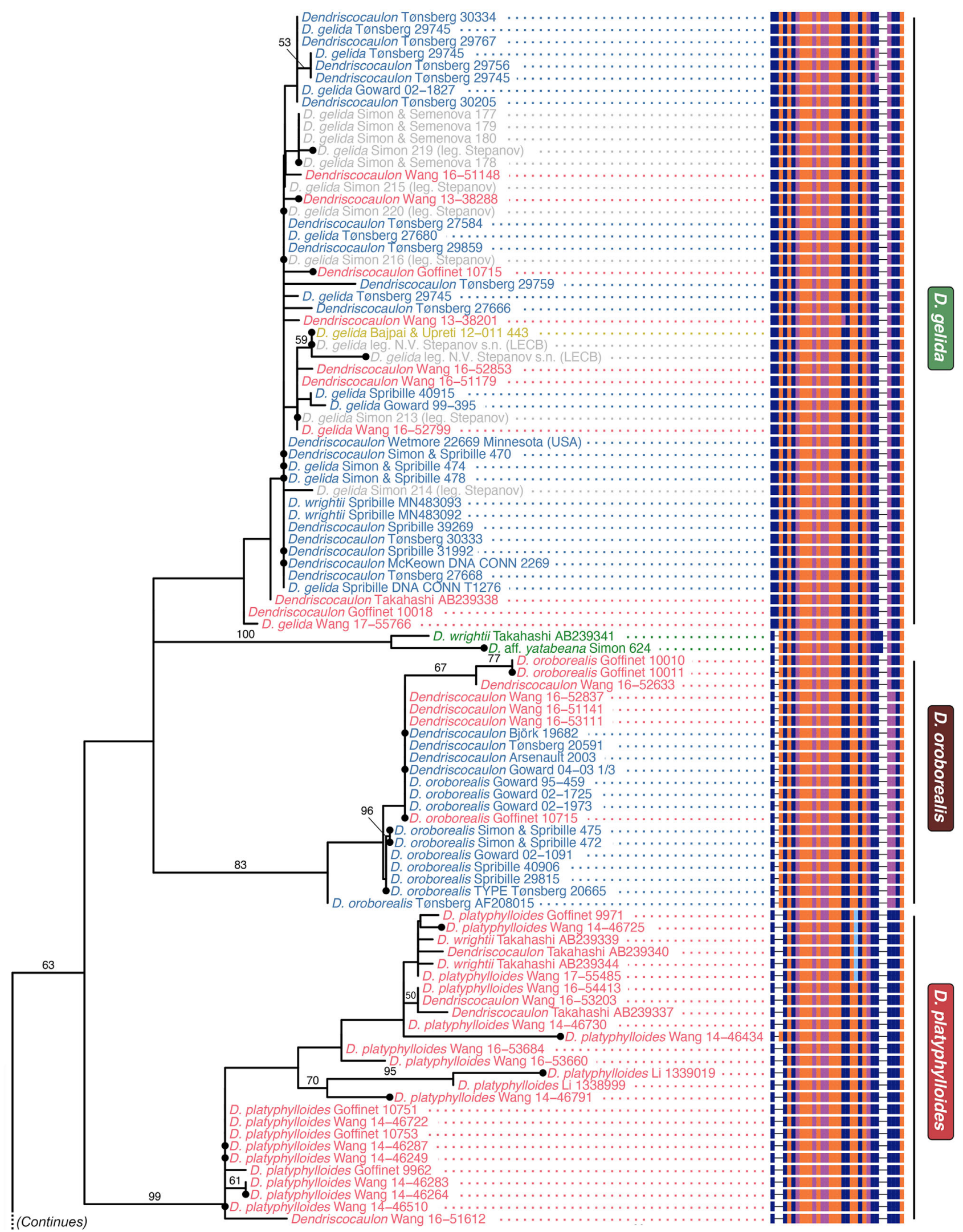

Fig. 5. Left: Single most likely phylogenetic tree of the Dendriscosticta wrightii clade obtained from inference of ITS. Values above branches represent ML bootstrap values (indicated when $\geq 50$ ). Colors in the taxa names refer to the origin of the samples (see legend in Fig. 3). Black dots indicate specimens present in the 4-locus dataset. Right: Portion of ITS2 allowing discrimination of the species (position 18-49). For accessions retrieved from GenBank, terminal labels indicate the original sequence labels. 


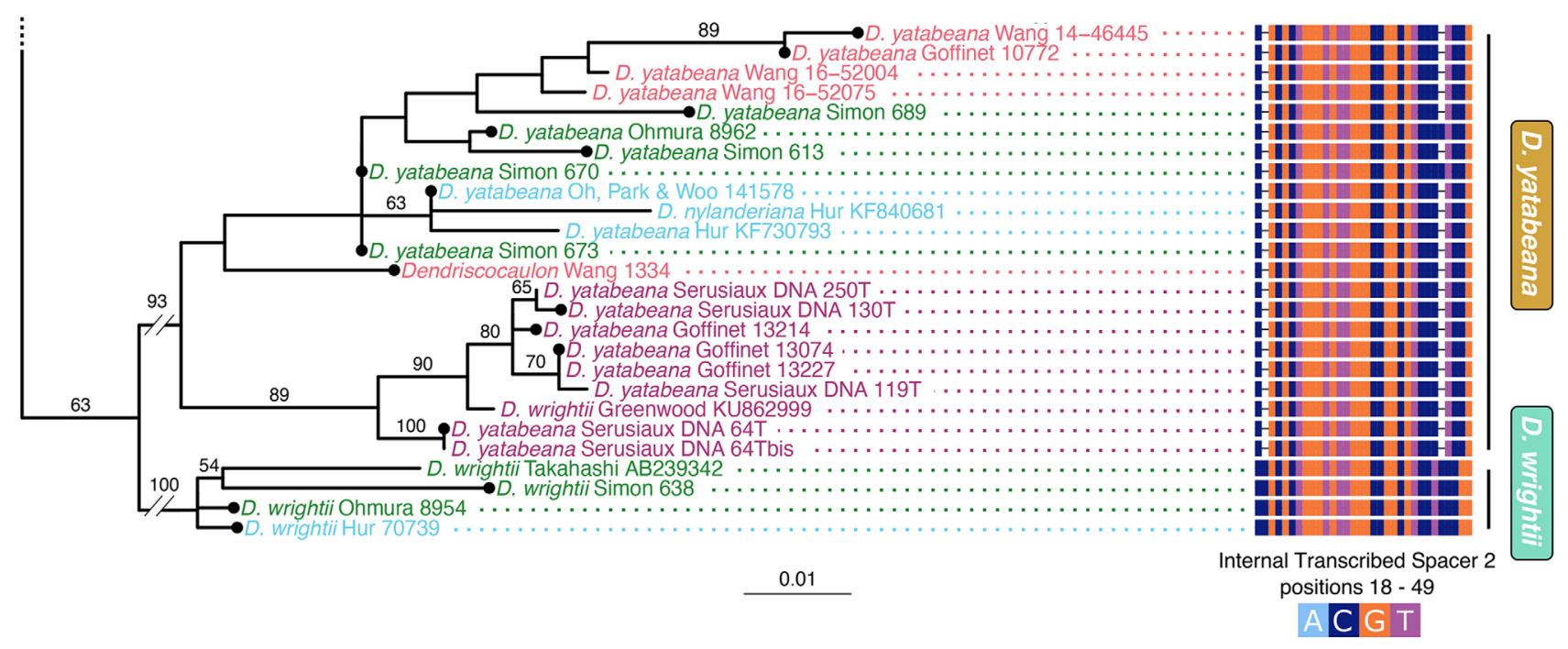

Fig. 5. Continued.

9.36 Mya (95\% highest posterior density [HPD]: 6.36-12.54 Mya) with subsequent diversification in each of these during the Pliocene, that is approximately 3.85 Mya (95\% HPD: $2.35-5$ for the $D$. praetextata clade and approximately 3.24 Mya (95\% HPD: 2.21-4.28 Mya) for the D. wrightii clade.

Assessment of short-sequence barcodes. - For all ITS2 barcode sequences designed to identify species within the Dendriscosticta wrightii clade, BLASTn top-scoring hits matched the species identity inferred from our phylogenetic inferences (suppl. Fig. S1), demonstrating the reliability of the short barcodes. However, due to the cryptic nature of this set of species, original identifications of sequences previously submitted to GenBank often differed from our revised taxonomic assessment. For this reason, we proposed a list of GenBank sequence accession numbers with corrected identifications in the context of the present study, including MycoBank registration numbers of the applicable names (suppl. Table S2). The best matches included the illegitimate genus Dendriscocaulon (under the unresolved sequence label "Dendriscocaulon sp."), the accepted species Dendriscosticta wrightii, and four species previously treated in Sticta but now transferred to the genus Dendriscosticta, viz. S. oroborealis ( $\equiv$ D. oroborealis), S. nylanderiana nom. illeg. (=D. hookeri comb. nov.), S. wrightii

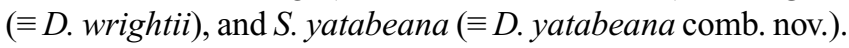

\section{DISCUSSION}

Accepted species and cryptic speciation. - In all analyses, accessions of Dendriscosticta were resolved in two main lineages (i.e., the $D$. wrightii and D. praetextata clades), a result consistent with the study by Moncada $\&$ al. (2013b), which identified an Eastern Hemisphere clade, with representatives producing gyrophoric acid in their medulla (i.e., the D. nylanderiana $=$ D. praetextata clade), and a mostly Western Hemisphere clade, whose representatives lack gyrophoric acid (i.e., the $D$. wrightii clade). Based on molecular, morphological and chemical evidence, we recognized nine species within the genus: four currently recognized species (i.e., D. oroborealis, $D$. platyphylloides, D. praetextata, and D. wrightii), three species newly transferred to Dendriscosticta (i.e., D. hookeri, $D$. insinuans, and D. yatabeana) and two newly described ones (i.e., D. gelida, and D. phyllidiata).

Notwithstanding these results, Dendriscosticta is appropriately regarded as a phylogenetically diverse and highly structured genus in which, however, morphological and chemical characters for species delimitation were comparatively few and subtle, consistent with studies on other groups within the Lobarioideae (e.g., Cornejo \& Scheidegger, 2015) and Peltigeroideae (e.g., Miadlikowska \& al., 2018). While we
Fig. 6. Alignment of nucleotide sequences within a portion of ITS2 (position 15-49) allowing identification of the five recognized species in the Dendriscosticta wrightii clade. Deviations are underlined, and lowercase letters represent nucleotides that can be present or not. IUPAC ambiguity codes were used.

\section{D. gelida}

\section{D. oroborealis}

D. platyphylloides

D. wrightii

D. yatabeana
GCCCCGCGCTGGGTGTTGGGYCGGCGTCY--TCCG GCCC_GCGCTGGGTGTTGGGCCGGCGTCC--TYCG

C-gCGCTGGGTGTTGGGCCGRCGTCC--CCCG CCGCGCTGGGTGTTGGGCCGGCGTCCTCCCGG 
were able to confirm several diagnostic characters within the genus (see key below), at least two characters previously used in the delimitation of Dendriscosticta species appear homoplasious across species: (1) the presence of irregular cyphellae in D. yatabeana versus rounded cyphellae in D. wrightii (Yoshimura, 1974; Jayalal \& al., 2014); and (2) the spot test reaction $\mathrm{K}+$ yellow in the $D$. wrightii clade, contrary to Yoshimura (1974) and Goward \& al. (1994), but consistent with Asahina (1961).

Although some species of Dendriscosticta could be readily distinguished by a combination of thallus morphology, distribution (suppl. Fig. S2) and to some extent chemistry (see key, below), several taxa nonetheless require molecular barcoding for reliable identification and hence qualify as cryptic species (Crespo \& Lumbsch, 2010). BLASTn results using our short barcoding sequences were in agreement with the phylogenetic-driven species hypotheses presented here, although the correct species was not obvious from simple inspection in most cases, given that identifications of previously submitted GenBank sequences were not necessarily in line with our revised taxonomy (suppl. Fig. S2). Given the phenotypic plasticity and complex taxonomy in these lichens, sequence identifications in GenBank often correspond to misidentifications or outdated taxonomic concepts (see suppl. Table S2 for proposed corrections). This underlines the notion that DNA barcoding may often be misleading not because of the underlying similarity-based algorithm or problems with the applied marker, but because the returned matches are not correctly identified (e.g., Hofstetter \& al., 2019; Lücking $\&$ al., 2020a). Indeed, our results demonstrate that accurate DNA sequence-based identification of Dendriscosticta species can be achieved using even very short portions of the ITS2 spacer region, thus providing support for metabarcoding approaches of short reads.

The limited phenotypic variation within Dendriscosticta might be indicative of recent speciation within this group, as suggested by our dating analysis, which suggests that most diversification events occurred primarily during the Pliocene (Fig. 8). Our decision to assign species status to cryptic taxa follows taxonomic treatments in other lichenized groups (e.g., Altermann \& al., 2016), and is consistent with direction given by the International Mycological Association regarding cryptic speciation in lichenized fungi, namely, to formally recognize morphologically cryptic species whose separation is supported by unambiguous phylogenetic signal and other evidence (Crespo \& Lumbsch, 2010), such as ecology or distribution, fixed nucleotide substitutions, and ultramicroscopic feature (Lumbsch \& Leavitt, 2011; Leavitt \& al., 2015). We believe that the proposed taxa represent independent metapopulation lineages worthy of specific recognition (De Queiroz, 2007), as the individual single-locus analyses produced congruent, monophyletic lineages in most cases (Taylor \& al., 2000; Dettman \& al., 2003). From this perspective, our phylogenetic analyses would indicate that the species recognized

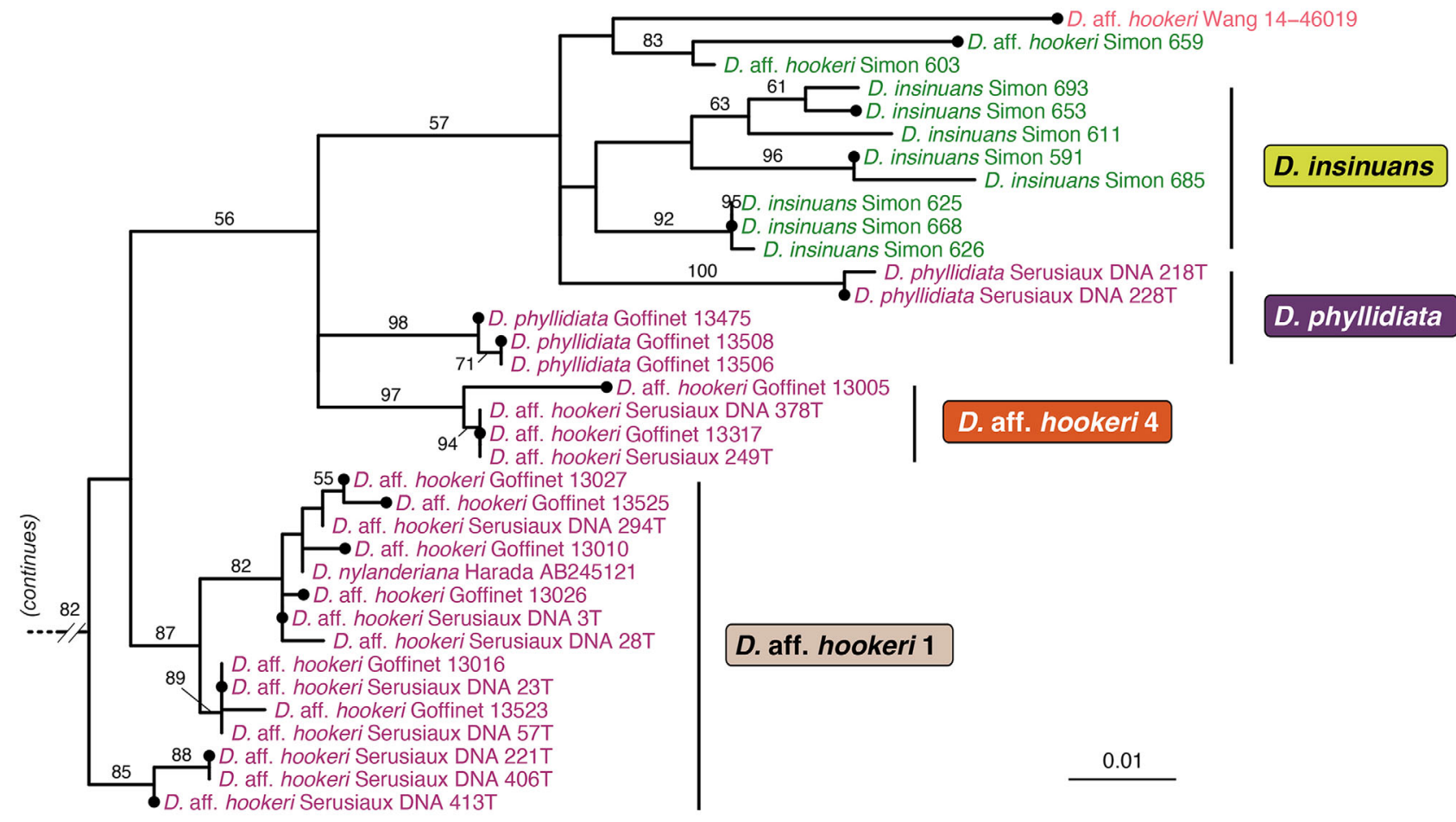

Fig. 7. Single most likely phylogenetic tree of the Dendriscosticta praetextata clade obtained from inference of ITS. Values above branches represent ML bootstrap values (indicated when $\geq 50$ ). Colors in the taxa names refer to the origin of the samples (see legend in Fig. 3). Black dots indicate specimens present in the 4-locus dataset. For accessions retrieved from GenBank, terminal labels indicate the original sequence labels. The crosshatched branch has been shortened to one tenth. 


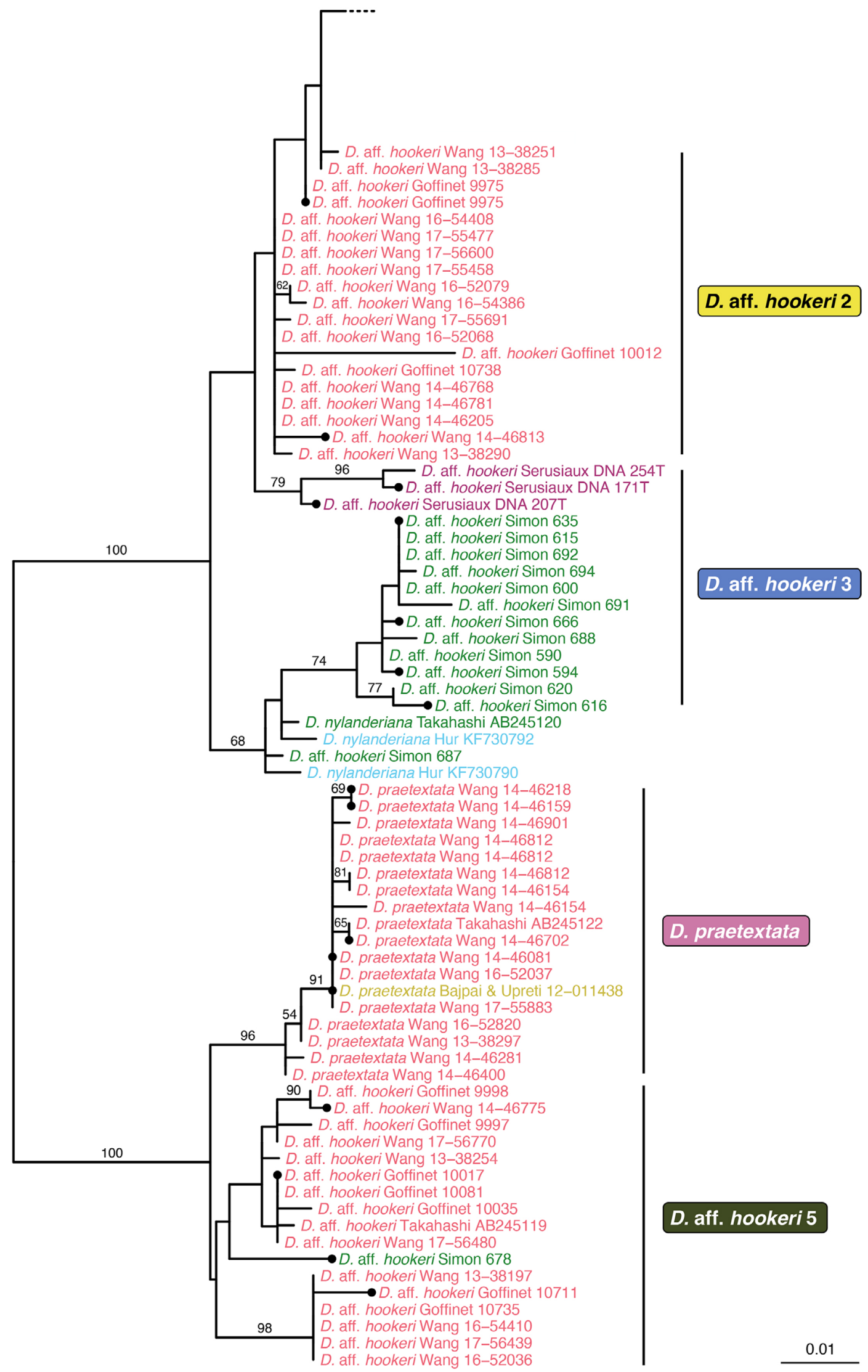

Fig. 7. Continued. 
within Dendriscosticta represent evolutionarily significant entities sensu Moritz (1994), worthy of specific conservation efforts.

Newly described species. - Within the Dendriscosticta wrightii clade, the newly described species $D$. gelida appears to be the most widespread, as it occurs throughout the Holarctic realm. Reports of $D$. wrightii from North America (e.g., Krog, 1968; Goward \& al., 1996; Stehn \& al., 2013; Esslinger, 2019) belong to this new taxon, and likely so do those from Europe (e.g., Krempelhuber, 1861, 1862; Türk \& Wunder, 2000; Fadeeva, 2005, 2009). Dendriscosticta gelida is clearly distinguishable morphologically from its strongly supported sister species D. oroborealis, which is sympatric in British Columbia (Tønsberg \& Goward, 2001). This was taken as evidence that the two clades are reproductively isolated lineages, and we therefore considered $D$. gelid $a$ and $D$. oroborealis two closely related but distinct species. The relatively young age of these sister species also weighs in favor of recognizing older, yet semi-cryptic, lineages within the $D$. wrightii clade as separate species despite the lack of unambiguous phenotypic discrimination.

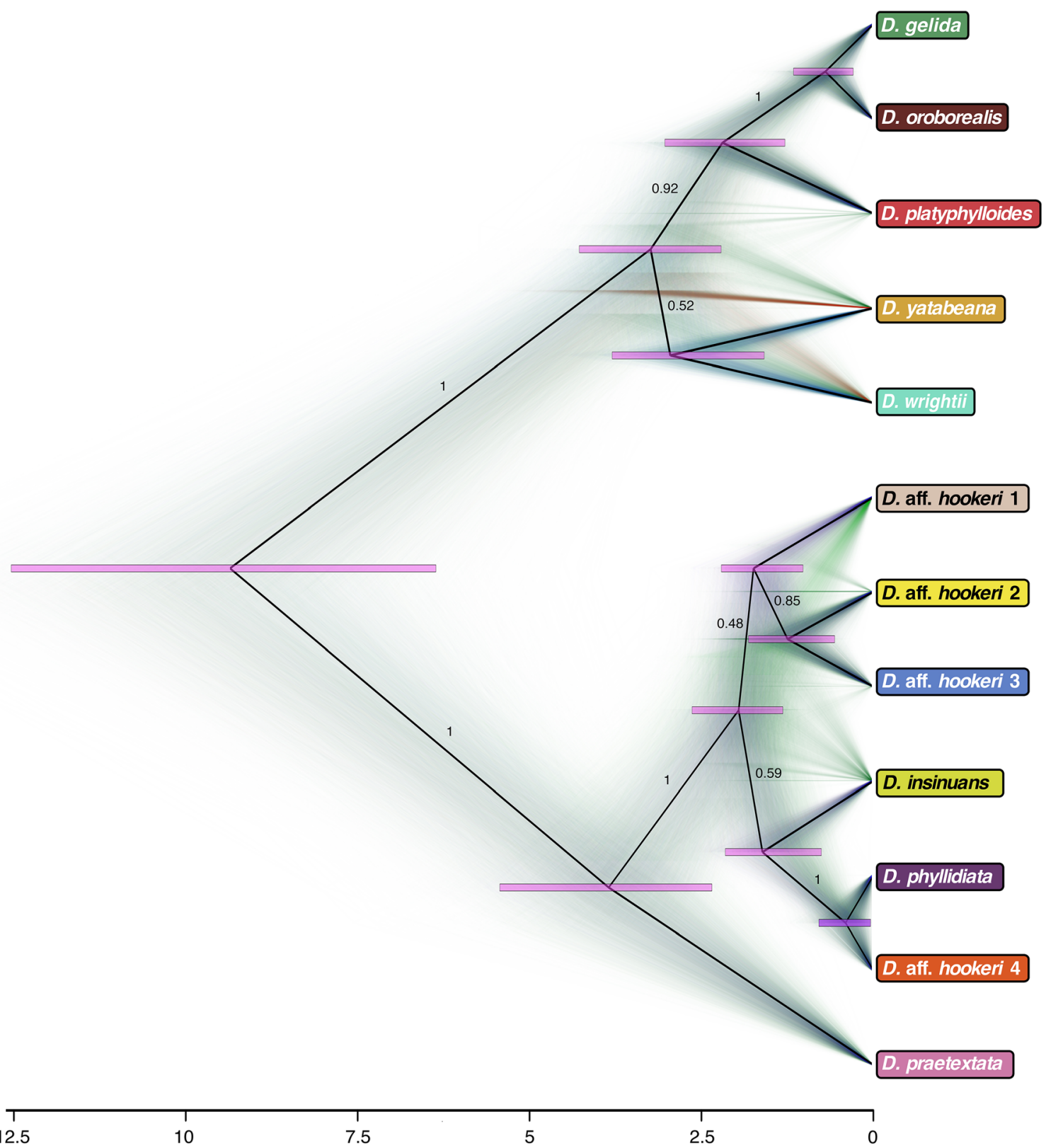

Fig. 8. Black lines: Dendriscosticta species tree obtained from a *BEAST analysis and estimated from a partitioned dataset consisting of four loci (ITS, RPB 1, EF1- $\alpha, M C M 7$ ) under a strict molecular clock. Values above branches represent posterior probabilities. The node bars indicate the $95 \%$ posterior density intervals. Colored lines: cloudogram of the posterior distributions of species trees from the *BEAST analysis. Areas where the majority of trees agree in topology and branch lengths are shown as darker, plain areas (well-supported clades), whereas areas with little agreement are shown as webs. The most popular tree is blue, the second most popular red, and the third most popular light green; the rest is dark green. Scale: millions of years before present. 
Within the Dendriscosticta praetextata clade, the newly described species $D$. phyllidiata can be easily set apart by its chemistry from the morphologically similar, and thus also phyllidiate $D$. praetextata, by the presence of congyrophoric acid. Furthermore, D. phyllidiata, whose recognition is supported by DNA-based species delimitation methods, appears to be restricted to Taiwan, whereas $D$. praetextata is mostly found in the eastern Himalayan range (northern India and southern China).

Taxonomic reassessment and epitypification. - Our detailed study of species delimitation within the genus demonstrates a notable array of cryptic species, challenging the assignment of historical type collections to a given lineage. Epitypification based on recently collected material from the type locality was considered necessary to apply available epithets based on old type specimens for which DNA data could not be acquired and whose taxonomic interpretation is thus ambiguous. To ensure nomenclature stability of Dendriscosticta wrightii and D. yatabeana, two species well-supported by DNA-based species delimitation methods, we followed the guidelines provided by Lendemer (2020) and epitypified these species using sequenced specimens from the type (or nearby) localities. In these two cases, we recently collected material from the geographic area from where the original type collection was gathered, to acquire exploitable DNA and sequences of the ITS barcode. Two epithets ( $S$. henryana Müll. Arg., $S$. hookeri (Trevis.) Nyl.) could not be evaluated as their geographical origin (Chinese province of Hubei and Nepal, respectively) was not explored as part of this study.

Using evidence from chemical and morphological data, we also propose new combinations for three species previously accommodated in Sticta: Dendriscosticta hookeri, $D$. insinuans, and D. yatabeana. While $S$. henryana unambiguously belongs to Dendriscosticta owing to its morphological features, we refrained from proposing a formal new combination for this species since the type locality was not sampled and we could not rule out that this species may be synonymous with another species within Dendriscosticta. The status of $D$. hookeri requires further investigation as the D. hookeri morpho- and chemotype is shared by an unresolved complex of several putative species.

\section{- TAXONOMIC TREATMENT}

\section{Key to recognized species of Dendriscosticta}

1 Chloromorph: thallus foliose; lobe tips scabrous and matt (appearing pruinose), usually upturned toward the tips; medulla $\mathrm{KC}-$ (gyrophoric acid absent). Cyanomorph: thallus dendriscocauloid (with Nostoc).

1 Chloromorph: thallus foliose; lobe tips smooth and glossy, and usually downturned toward the tips; medulla $\mathrm{KC}+$ red (gyrophoric acid present). Cyanomorph: not observed....5

2 Chloromorph: lobes pale green when wet, broadly rounded, not much longer than wide, without scalloped or lacerate margins; thallus becoming pinkish in the herbarium; cortex usually $\mathrm{K}+$ yellow (pseudocyphellarin A usually present). Cyanomorph: usually rhizinate. Distribution: western Canada and southern China. ITS2 barcode: CGCGCTGGGTGTTGGGCCGGCGTCCTYCG .

D. oroborealis

2 Chloromorph: lobes dark green when wet, typically longer than wide, sometimes with scalloped or lacerate margins; thallus color unchanged in the herbarium; cortex $\mathrm{K}+$ yellow or $\mathrm{K}$ - (pseudocyphellarin A present or absent). Cyanomorph: without rhizines. Distribution: various. ITS2 barcode: not as above.

3

3 Chloromorph: lobe underside usually whitish to beige, covered by a pale brown tomentum; cortex $\mathrm{K}+$ yellow (pseudocyphellarin A almost always present). Distribution: southern China. ITS2 barcode: C(G)CGCTGGGTGTTGGGCCGRC GTCCCCCG D. platyphylloides

3 Chloromorph: lobe underside usually beige to brown, covered by a dark brown to black tomentum; cortex generally $\mathrm{K}$ - (pseudocyphellarin A usually absent). ITS2 barcode: not as above

...4

4 Distribution: East Asia, Russia, northwestern North America, northern India. ITS2 barcode: CCGCGCTGGGTGTT GGGYCGGCGTCYTCCG ................................. g. gelida

4 Distribution: Japan, South Korea. ITS2 barcode: CCGCGC TGGGTGTTGGGCCGGCGTCCTCCCGG....D. wrightii

4 Distribution: East Asia. ITS2 barcode: CGCGCTGGG TGTTGGGCCGGCGTCCC $(C)$ TCCG ....... D. yatabeana

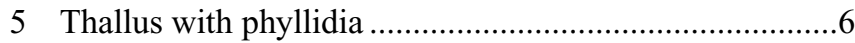

5 Thallus without phyllidia .................................................

6 Congyrophoric acid present. Distribution: Taiwan. ITS2 barcode: CAACGCCATGTCGCTCGGC ............ D. phyllidiata

6 Congyrophoric acid absent. Distribution: southern China to northern India. ITS2 barcode: GGCCGACGTYCCG TTC ......................................................... D. praetextata

7 Distribution: Japan. ITS2 barcode: CAYGCCATGTCG CTCGGCRG …......................................... insinuans

7 Distribution: East Asia (southern China, Japan, South Korea, Taiwan). ITS2 barcode: not as above.

D. hookeri aggregate

Notes: Barcodes represent homologous positions within each clade. The sequence corresponds to a portion of ITS2 of the nuclear ribosomal DNA repeat in position 15-49 and 104-122 for the Dendriscosticta wrightii clade and the $D$. praetextata clade, respectively. Letters placed in parentheses represent nucleotides that can be present or not.

Dendriscosticta gelida Ant.Simon, Goward \& T.Sprib., sp. nov. [MB 835910] - Holotype: Russia. Komi Republic: Priluzsky District, approximately $4 \mathrm{~km} \mathrm{~W}$ of the ghost village of Pentjura (Пентюра) and $11 \mathrm{~km} \mathrm{NW}$ of Lojma (Лойма), $60^{\circ} 35^{\prime} 16^{\prime \prime} \mathrm{N}, 48^{\circ} 37^{\prime} 37^{\prime \prime} \mathrm{E}$, on Sorbus trunk, in old mixedwood forest of Picea-Sorbus, 24 Aug 2017, A. Simon 177 \& N. Semenova (LE barcode LE L-16211; isotypes: $\mathrm{LG}, \mathrm{UBC})$.

Fig. 9A-D 
Exsiccata. - RUSSIA, Rossia septentrionalis, regio et distr. Vologdaensis, praedium sylvaticum Jaroslavskaja in silva ad ramos Picea excelsae, 1928, leg. Am. Leontjev (V.P. Savicz, Lichenotheca Rossica No. 107, TU!).

Etymology. - The epithet is based on the Latin word geli$d u s$, meaning cold, frosty, icy, referring to the characteristic "frosted" appearance of the lobe tips.

Diagnosis. - Thallus dimorphic. Chloromorphic thallus macrofoliose, similar to Dendriscosticta oroborealis but differing by the longer, often more or less dissected lobes.
Cyanomorphic thallus fruticose (dendriscocauloid), differing from $D$. oroborealis in the absence of rhizines.

Description. - Chloromorph: photobiont green (presumably Dictyochloropsis s.1.). Stipe absent. Thallus foliose, epiphytic, radially plicate-rugose, orbicular in outline, up to $15 \mathrm{~cm}$ in diam., coriaceous and resistant, rather thick, branching anisotomous or pleurotomous. Lobes somewhat involute, ligulate, imbricate, longer than wide, more or less ascending; margins sinuose to rather lacerate, slightly thickened; lobe internodes 4-20 mm long. Upper surface smooth or weakly
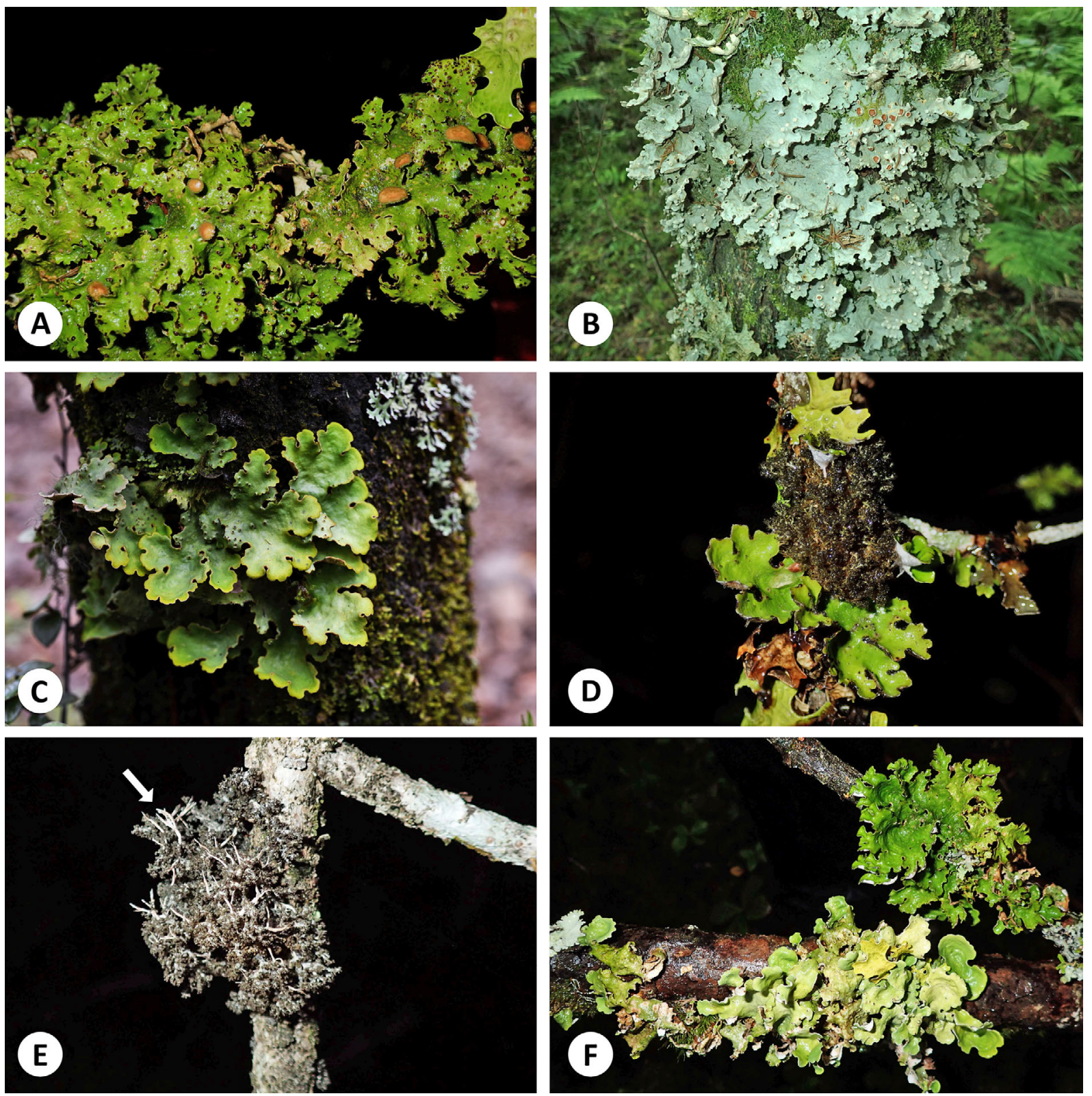

Fig. 9. Habit of Dendriscosticta species. A-C, D. gelida (A, field image from British Columbia; B, Simon 178, LG: topotype; C, Wang 17-55766, KUN), showing upper surface with numerous apothecia (A, B) and pycnidia (C); D, Photomorphs pair of D. gelida (Simon 441, LG), showing foliose chloromorph (bottom) and fruticose, dendriscocauloid cyanomorph (top); E, Free-living cyanomorph of D. oroborealis (Simon 446, LG), showing characteristic rhizines (arrow); F, D. oroborealis (bottom, Simon 472, LG) and D. gelida (top right, Simon 449, LG). - Photographs by A. Simon (A, B, D-F) and L.S. Wang (C). 
rugose, dark green when fresh, paler toward margins, turning pale brown in herbarium, opaque, with margin concolorous; surface scabrose, or seemingly pruinose, due to the presence of cortical hairs, especially along margin. Cilia absent. Apothecia either absent, or if present, then usually abundant, cup-shaped, up to $7 \mathrm{~mm}$ diam., laminal, dispersed, pedicellate, with pronounced basal invagination, with glossy orange disk. Medulla compact, white, $\mathrm{K}-$ (cortex rarely $\mathrm{K}+$ yellow), $\mathrm{C}-, \mathrm{KC}-, \mathrm{P}-$. Lower surface smooth, cream to brown-colored. Lower tomentum dense throughout, patchily thick and thin, spongy, soft or rough, concolorous with lower surface. Rhizines sparse, dispersed, fasciculate, cream to browncolored, up to $5 \mathrm{~mm}$ long. Cyphelloid pores abundant, 21-40 per $\mathrm{cm}^{2}$ (central) to $41-60$ per $\mathrm{cm}^{2}$ (marginal), dispersed, rounded to irregular, urceolate with wide pore, immersed, below level of tomentum, with cream to brown-colored etomentose margins; pore to $3 \mathrm{~mm}$ in diam; basal membrane pruinose, white. Pycnidia occasionally present, immersed, with black ostiole.

Upper cortex paraplectenchymatous, 35-65 $\mu \mathrm{m}$ thick, homogeneous, consisting of 6-8 cell layers with cells $6-10 \mu \mathrm{m}$ diam., their lumina round-isodiametric. Photobiont layer 20$35 \mu \mathrm{m}$ thick, cells $4.5-7.5 \mu \mathrm{m}$ diam. Medulla $260-430 \mu \mathrm{m}$ thick, hyphae c. $5 \mu \mathrm{m}$ broad, without crystals. Lower cortex paraplectenchymatous, $20-40 \mu \mathrm{m}$ thick, with 3-5 cell layers; cells $5-11 \mu \mathrm{m}$ diam. Hairs of lower tomentum in fascicles of 6-12 hyphae with intertwined apices. Cephalodia usually present (internal). Cyphelloid pores with cells of basal membrane polygonal and entangled, 3-5 $\mu \mathrm{m}$ wide, without papillae.

Apothecia occasionally present, excipulum containing algae and with lateral verrucose protuberances. Hymenium 120-220 $\mu \mathrm{m}$ high. Ascospores 1-3-septate, acicular, 40-50 $\times$ 3-4 $\mu \mathrm{m}$, hyaline.

Cyanomorph: thallus fruticose (dendriscocauloid); photobiont blue-green (Nostoc).

ITS2 barcode. - GCCCCGCGCTGGGTGTTGGGYC GGCGTCYTCCG.

Chemistry. - No substances detected by TLC.

Distribution. - In North America, the species is present in Canada (British Columbia) and the United States (Alaska, Michigan, Minnesota), where it was previously treated under the name Sticta wrightii (Krog, 1968; Goward \& al., 1996; Tønsberg \& Goward, 2001; Stehn \& al., 2013). Confirmed from northern India (Uttarakhand) and southern China (Xinzang, Sichuan, Yunnan). In Russia, confirmed from the Komi Republic and Krasnoyarsk Krai; the specimens reported as Dendriscosticta wrightii (or S. wrightii) from Karelia, Kostroma Oblast and Perm Krai (Fadeeva, 2005, 2009; Kuznetsova \& Skazina, 2010; Karasev \& Selivanov, 2014) most likely belong to this species as well since $D$. wrightii was not detected in Russia in our dataset. However, these records need confirmation.

Comments. - Dendriscosticta gelida is the most widespread species of the genus, ranging from China to Eurasian Russia and northwest North America. Earlier reports of D. (Sticta) wrightii from North America and Russia (e.g., Krog, 1968; Makryi, 2008; Esslinger, 2019; Spribille \& al., 2020) belong to this species. Sticta wrightii has also been reported from Germany (Krempelhuber, 1862; Türk \& Wunder, 2000), but all records are historical and the taxon is likely extinct in this region. Although these old European records probably belong to $D$. gelida, the material from Germany has scattered marginal lobules, and hence its identity remains uncertain (H. Lojka: Lichenotheca Universalis. Fasc. II (1885) N. 67. Ricasolia Wrightii (Tuck.) Nyl., "in cortice Aceris prope Berchtesgaden in Bavaria. Leg. Rauchenberger - Perpauca specimina accepi e reliquiis beati von Krempelhuber"; observed in G).

Additional specimens examined. - Refer to Appendix 2.

Dendriscosticta hookeri (Trevis.) Moncada \& Lücking, comb. nov. [MB 835912] E Lobaria hookeri Trevis. in Lichenoth. Veneta 1-2: no. 77. $1869 \equiv$ [nom. nov. pro] Sticta platyphylla Nyl., Syn. Meth. Lich. 1: 357. 1860, nom. illeg., non S. platyphylla A.Massal., Mem. Lichenogr: 32. 1853, 三 Sticta nylanderiana Zahlbr., Cat. Lich. Univ. 3: 356. $1925 \equiv$ Stictina nylanderiana (Zahlbr.) C.W.Dodge, Beih. Nova Hedwigia 12: 193. 1964 - Lectotype (designated by Joshi \& Awasthi in Biol. Mem. 7: 183. 1982): Nepal. J.D. Hooker \& T. Thomson 1963 (H-NYL No. 33652 [H barcode H9505981]!).

Fig. 10A,B

Description (type). - Thallus macrofoliose, subcoriaceous, rather thin, branching anisotomous, primarily associated with a green alga; other features, such as presence of stipe or diameter, not discernable as only a small portion is preserved. Lobes more or less plane, flabellate, adjacent, approximately as long as wide, adnate, with relatively plane apices; margins plane; lobe internodes 3-5 mm long. Upper surface smooth, brownish in herbarium, slightly glossy, with margin concolorous; surface smooth (without tomentum), without papillae, pruina and cortical hairs. Cilia absent. Apothecia abundant, cup-shaped, up to $2.5 \mathrm{~mm}$ in diam., laminal, dispersed but dense, shortly pedicellate, without basal invagination (or weak), with slightly glossy, dark brown disk. Cortex $\mathrm{K}+$ yellow. Medulla white, $\mathrm{KC}+$ pink to red. Lower surface not discernable (as the small piece is glued to cardboard). Lower tomentum visible along the margins, rather thin, dark brown. Rhizines and cyphelloid pores not discernable. Pycnidia not observed.

Apothecia with laterally more or less smooth margins. Ascospores 1-3-septate, fusiform, 30.7-40.9 × 4.6-5.1 $\mu \mathrm{m}$ (annotated by K. Takahashi, March 2003).

Chemistry. - Gyrophoric acid, congyrophoric acid and pseudocyphellarin A (annotated by K. Takahashi, March 2003).

Distribution. - Reported (generally as Sticta platyphylla or S. nylanderiana) from Bhutan (Upreti \& Ranjan, 1988), China (Wei, 1991; Chen \& al., 1994), India (Joshi \& al., 2016), Japan (Yoshimura, 1974; Ohmura \& Kashiwadani, 2018), Mongolia (Biazrov, 2013), Nepal (Devkota \& al., 2017), Russia (Budaeva, 2014; Makryi, 2008), South Korea (Jayalal \& al., 2014) and Thailand (Wolseley \& al., 2002; Buaruang \& al., 2017). In light of our results, these records likely represent several cryptic species, and further molecular studies are needed to clarify the taxonomy of this species-complex. 
Comments. - The publication of the homonymic names Sticta platyphylla A.Massal. (Massalongo, 1853) and S. platyphylla Nyl. (Nylander, 1860) has led to much taxonomic confusion. The first (Massalongo, 1853) is based on a collection from Martinique and appears to belong to Sticta s.str., i.e., unrelated to Dendriscosticta. The second (Nylander, 1860) is based on a collection by J.D. Hooker and T. Thomson from Nepal that unambiguously belongs to Dendriscosticta, but the name unfortunately represents an illegitimate later homonym. Trevisan (1869) published in his exsiccata Lichenotheca Veneta a specimen that he believed was conspecific with $S$. platyphylla A.Massal., and combined it into Lobaria platyphylla (A.Massal.) Trevis. In the same publication, he also realized that $S$. platyphylla Nyl. was a later homonym and gave it a replacement name, $L$. hookeri Trevis. He did not mention a specimen along with that replacement name, so it is automatically typified by the type of Nylander's name. Subsequent confusion originated from Zahlbruckner (1925), who made no distinction between the two taxa originally described by Massalongo (1853) and Nylander (1860), despite their unrelatedness, placing L. platyphylla (A.Massal.) Trevis. in synonymy of S. platyphylla Nyl. He then introduced a superfluous replacement name for the latter, S. nylanderiana Zahlbr., when under his concept, the name Sticta platyphylla A.Massal. would have been available. He also associated Trevisan's combination with nos. 75 and 76 in Trevisan's Lichenotheca Veneta, when in fact
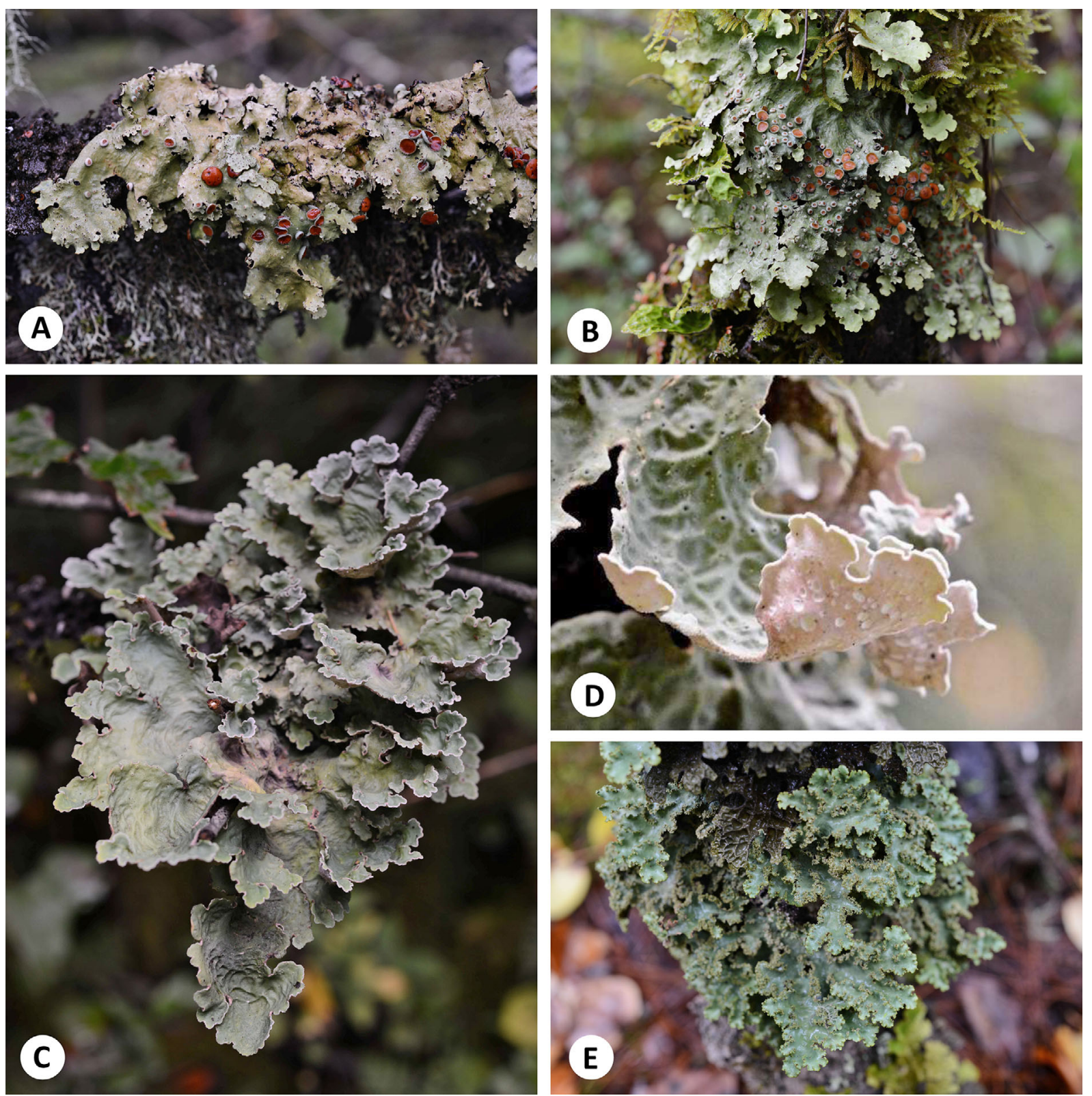

Fig. 10. Habit of Dendriscosticta species. A \& B, D. aff. hookeri 2 (A, Wang 17-55477, KUN; B, Wang 16-52079, KUN), showing upper surface with numerous apothecia; C \& D, D. platyphylloides (C, Wang 16-53660, KUN; D, Wang 16-53684, KUN), showing upper surface (C) and close-up of lobe tips with cyphellae (D); E, D. praetextata (Wang 16-52037, KUN), showing upper surface with phyllidia. - Photographs by L.S. Wang. 
the correct number would have been 77 (http://dryades.units.it/ lichenothecaveneta/index.php?procedure $=$ taxonpage $\&$ taxon $=$ 77). Number 76 refers to L. macrophylla (Bory) Trevis. and no. 75 to L. pulmonaria (L.) Hoffm.; however, as part of the label of the latter, Trevisan (1869) gave a summary outline of his concept of Sticta and related genera, where all names treated by him are listed, including the replacement name Lobaria hookeri Trevis. for Sticta platyphylla Nyl. (http:// dryades.units.it/lichenothecaveneta/index.php?procedure= taxonpage\&taxon=75).

Moncada \& al. (2013b) were unaware of Zahlbruckner's misinterpretation and followed Index Fungorum in considering Lobaria platyphylla sensu Trevis. as replacement name for Sticta platyphylla Nyl. However, L. platyphylla sensu Trevis. must be considered a legitimate combination of the legitimate basionym Sticta platyphylla A.Massal., as L. platyphylla (A.Massal.) Trevis., referring to a green-algal species of Sticta s.str. Therefore, the combination Dendriscosticta platyphylla sensu Moncada \& al. is invalid, as by extension, and unintentionally, it refers to $S$. platyphylla A.Massal., not $S$. platyphylla Nyl., and no valid basionym was cited; it also has to be considered a homotypic synonym of S. platyphylla A.Massal. The correct replacement name for S. platyphylla A.Massal. is Lobaria hookeri Trevis., which is therefore the epithet to be adopted in Dendriscosticta.

Our sampling and DNA-based species delimitation highlighted several supported lineages with the morphochemotype of Dendriscosticta hookeri. Unfortunately, the lectotype is minuscule and does not show unique features linking it unambiguously to a particular clade. As the type region could not be assessed from the original label and no fresh material suitable for DNA extraction and sequencing was available from the type region, it is currently not possible to assign the epithet hookeri with certainty to one of these lineages. However, based on the geographic origin of the type and the annotated chemistry (containing pseudocyphellarin A), currently only " $D$. aff. hookeri 2 " or " $D$. aff. hookeri 5 " would be conceivable matches, both of which are known from China and produce pseudocyphellarin A.

Dendriscosticta insinuans (Nyl.) Ant.Simon, Magain \& Sérus., comb. nov. [MB 835913] $\equiv$ Sticta insinuans Nyl., Lich. Jap.: 30. 1890 - Syntypes: Japan. Itchigòmé, 1879, E. Almquist s.n. (S No. F158658 n.v.); Fusijama Itjigome, E. Almquist s.n. (S No. F158659 n.v.).

Fig. 11F

Description. - Photobiont green (presumably Dictyochloropsis s.1.). Stipe absent. Thallus foliose, epiphytic, orbicular in outline, up to $10 \mathrm{~cm}$ in diam., subcoriaceous, rather thin, branching anisotomous or pleurotomous. Lobes somewhat revolute or undulate, flabellate or ligulate, imbricate, approximately as long as wide, adnate, with relatively plane apices; margins plane to undulate; lobe internodes 3-20 mm long. Upper surface smooth, green when fresh, turning brown in herbarium, glossy, with margin concolorous; surface smooth (without tomentum), without papillae, pruina and cortical hairs. Cilia absent. Apothecia either absent, or if present usually abundant, cup-shaped, up to $4 \mathrm{~mm}$ in diam., laminal, dispersed, pedicellate, without basal invagination (or weak), with glossy, orange to brown disk. Cortex $\mathrm{K}+$ yellow or $\mathrm{K}-$. Medulla compact, white, $\mathrm{K}-, \mathrm{C}+$ salmon pink, $\mathrm{KC}+$ salmon pink, $\mathrm{P}-$. Lower surface smooth, cream to brown-colored. Lower tomentum dense, absent towards margin, rather thin, concolorous with lower surface. Rhizines sparse, dispersed, fasciculate or tomentose, cream to brown-colored, up to $2 \mathrm{~mm}$ long. Cyphelloid pores abundant, 41-60 per $\mathrm{cm}^{2}$ (central) to $21-40$ per $\mathrm{cm}^{2}$ (marginal), dispersed, rounded to irregular, urceolate with wide pore, immersed, below level of tomentum, with cream to browncolored margins; pore to $1.5(-3) \mathrm{mm}$ in diam.; basal membrane pruinose, white. Pycnidia immersed, with blackish ostiole.

Upper cortex paraplectenchymatous, c. $40 \mu \mathrm{m}$ thick, homogeneous, consisting of 4-5 cell layers with cells $5-9 \mu \mathrm{m}$ diam., their lumina round-isodiametric. Photobiont layer c. $30 \mu \mathrm{m}$ thick, its cells 5-7 $\mu \mathrm{m}$ diam. Medulla 200-260 $\mu \mathrm{m}$ thick, its hyphae c. $5 \mu \mathrm{m}$ broad, with gyrophoric acid crystals. Lower cortex paraplectenchymatous, $30-35 \mu \mathrm{m}$ thick, with 2 3 cell layers; cells 5-9 $\mu \mathrm{m}$ diam. Hairs of lower tomentum in fascicles of 6-12 hyphae with intertwined apices. Cephalodia usually present (internal). Cyphelloid pores with cells of basal membrane polygonal and entangled, 3-5 $\mu \mathrm{m}$ wide, without papillae.

Apothecia with excipulum containing algae, with lateral verrucose protuberances. Hymenium 150-250 $\mu \mathrm{m}$ high. Ascospores 1-3-septate, fusiform, 35-55 × 5-6.5 $\mu \mathrm{m}$, hyaline.

ITS2 barcode. - CAYGCCATGTCGCTCGGCRG.

Chemistry. - Gyrophoric acid and congyrophoric acids.

Distribution. - Reported from Japan (Yoshimura, 1974) and Russia (Blum \& al., 1975; Makryi, 2008). In his protologue, Nylander (1890) mentioned similar material collected by H. Cuming from the Philippines. Confirmed only from Japan based on the results presented here.

Comments. - In the protologue, Nylander (1890) cites original material, presumably collected by E. Almquist from Itchigòmé, which refers to Mount Fuji, Shizuoka Prefecture, Honshu, Japan. Two specimens collected by E. Almquist in this region (F158658, F158659) are in $\mathrm{S}$ under the basionym in the general collection (i.e., not recognized as type material). While at least one of these samples could undoubtedly serve as a reference for the original description and would be appropriate for lectotypification, we refrained from designating a lectotype as the general collection at $\mathrm{S}$ was inaccessible at the time of this study. Once a lectotype is formally selected for this species, the designation of an interpretative type (epitype) may be needed to clarify the application of this species name.

Specimens examined. - Refer to Appendix 2.

Dendriscosticta oroborealis (Goward \& Tønsberg) Moncada \& Lücking in Lichenologist 45: 223. $2013 \equiv$ Sticta oroborealis Goward \& Tønsberg in Bryologist 104: 19. 2001 
- Holotype: Canada. British Columbia: N of Hazelton, E of Kispiox Range, N of Date Creek 17 km NW of Kispiox, along and $\mathrm{W}$ of a gravel road near a small unnamed creek, $55^{\circ} 24.7^{\prime} \mathrm{N}, 127^{\circ} 48.2^{\prime} \mathrm{W}, 510 \mathrm{~m}$, on twig of Tsuga heterophylla in shaded ravine, 3 Oct 1994 T. Tønsberg 20665 \& T. Goward (BG!; isotype: CANL n.v.).

Fig. 9E,F

Short description. - Thallus dimorphic. Chloromorphic thallus macrofoliose, similar to Dendriscosticta gelida, but with lobes shorter than wide and entire, not at all lacerate. Cyanomorphic thallus fruticose (dendriscocauloid), differing from $D$. gelida by the presence of rhizines. For a detailed description, see Tønsberg \& Goward (2001).

ITS2 barcode. - GCCCGCGCTGGGTGTTGGGCCGG CGTCCTYCG.

Chemistry. - Pseudocyphellarin A usually present.

Distribution. - Known from British Columbia (Canada; Tønsberg \& Goward, 2001) and newly reported from southern China. A new collection from the Incomappleux drainage (British Columbia) represents a significant range extension compared to its previously known distribution in Canada.
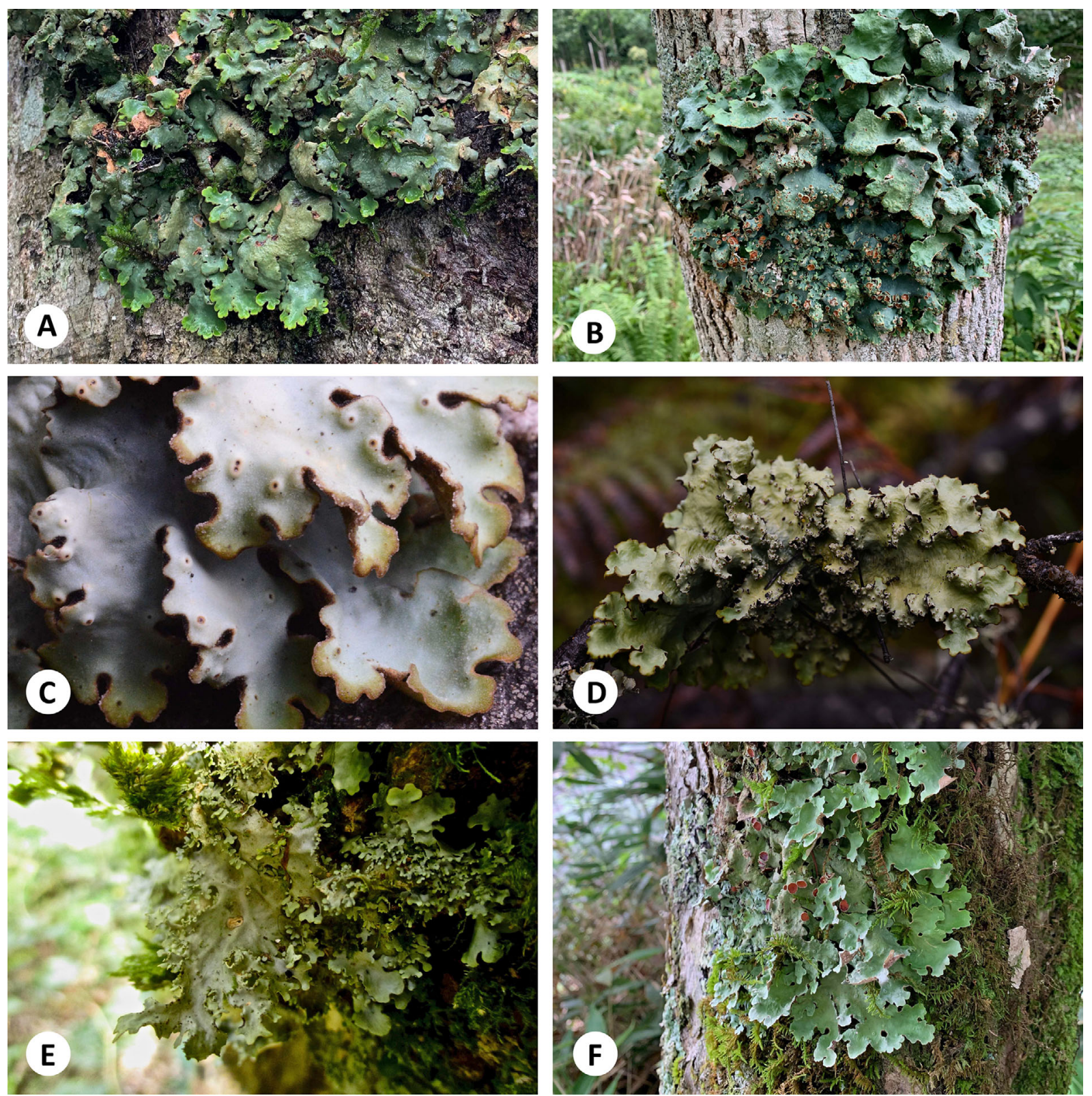

Fig. 11. Habit of Dendriscosticta species. A, D. wrightii (Simon 638: epitype, FH); B-D, D. yatabeana (B, Simon 613, LG; C, Wang 14-46445, KUN; D, Wang 16-52075, KUN), showing upper surface with numerous apothecia (B), close-up of seemingly pruinose lobes with hyphae protruding from the cortex (C), and upper surface with pycnidia (C \& D); E, D. phyllidiata (field image from Taiwan), showing upper surface with phyllidia; F, D. insinuans (Simon 668, TNS), showing upper surface with apothecia. — Photographs by A. Simon (A, B, F), L.S. Wang (C, D) and B. Goffinet (E). 
Comments. - Assignment of this taxon is unambiguous as the holotype is included in our phylogenetic analyses. Additional specimens examined. - Refer to Appendix 2.

Dendriscosticta phyllidiata Ant.Simon, Goffinet \& Sérus., sp. nov. [MB 835911] - Holotype: Taiwan. Chiayi County: Alishan Township, Alishan Range, Alishan National Forest Recreation Area, Alpine Botanical Garden, below alpine garden, $23^{\circ} 30.149^{\prime} \mathrm{N}, 120^{\circ} 49.367^{\prime} \mathrm{E}, \pm 2480-2500 \mathrm{~m}$, on large Acer, 25 Oct 2016, B. Goffinet 13475 \& E. Sérusiaux (TAIE barcode TAIE046233!; isotype: CONN!).

Fig. 11E

Etymology. - This taxon is named after its most characteristic feature, the production of abundant phyllidia, mostly at lobe margins.

Diagnosis. - Thallus macrofoliose with abundant, marginal phyllidia; differing from Dendriscosticta praetextata in the presence of congyrophoric acid.

Description. - Photobiont green (presumably Dictyochloropsis s.1.). Stipe absent. Thallus foliose, epiphytic, orbicular in outline, up to $15 \mathrm{~cm}$ in diam., papyraceous and fragile, usually rather thick when dry, branching pleurotomous or polytomous. Lobes somewhat involute or undulate, ligulate, imbricate, adnate, with plane apices; margins lacerate or crisp, not thickened; lobe internodes 3-15 mm long. Upper surface smooth, green when fresh, turning light brown in herbarium, moderately glossy, with margin concolorous; surface smooth (without tomentum), without papillae, pruina and cortical hairs. Cilia absent. Apothecia either absent, or if present, sparse, cup-shaped, up to $2 \mathrm{~mm}$ in diam., laminal, dispersed, pedicellate, without basal invagination (or weak), with glossy, orange disk. Phyllidia abundant, marginal (rarely laminal), dispersed, unbranched, palmate, up to $2 \mathrm{~mm}$ long and $0.6 \mathrm{~mm}$ wide, glossy, dorsiventral, lobuliform. Medulla compact, white, $\mathrm{K}$ - (cortex occasionally $\mathrm{K}+$ yellow), $\mathrm{C}+$ salmon pink, $\mathrm{KC}+$ salmon pink, $\mathrm{P}-$. Lower surface smooth, cream to brown-colored. Lower tomentum dense, absent towards margin, rather thick, fasciculate or spongy, soft or rough, concolorous with lower surface. Rhizines sparse, centrally aggregate, fasciculate or penicillate, cream to brown-colored, up to $5 \mathrm{~mm}$ long. Cyphellae abundant, 41-60 per $\mathrm{cm}^{2}$ (central) to $21-40$ per $\mathrm{cm}^{2}$ (marginal), dispersed, rounded to irregular, urceolate with wide pore, immersed, below level of tomentum, with cream to brown-colored margins lacking tomentum; pore to $1.5 \mathrm{~mm}$ in diam.; basal membrane pruinose, white, $\mathrm{K}-, \mathrm{C}+$ salmon pink, $\mathrm{KC}+$ salmon pink, $\mathrm{P}-$. Pycnidia immersed, with blackish ostiole.

Upper cortex paraplectenchymatous, c. $25-45 \mu \mathrm{m}$ thick, homogeneous, consisting of 4-6 cell layers with cells 5-8 $\mu \mathrm{m}$ diam, their lumina round-isodiametric. Photobiont layer 30$40 \mu \mathrm{m}$ thick, its cells c. $5 \mu \mathrm{m}$ diam. Medulla $120-180 \mu \mathrm{m}$ thick, its hyphae c. $5 \mu \mathrm{m}$ broad, with gyrophoric acid crystals. Lower cortex paraplectenchymatous, $15-35 \mu \mathrm{m}$ thick, with 23 cell layers; cells $6-8 \mu \mathrm{m}$ diam. Hairs of lower tomentum in fascicles of 6-12 hyphae with intertwined apices. Cephalodia not observed. Cyphelloid pores with cells of basal membrane polygonal and entangled, 3-5 $\mu \mathrm{m}$ wide, without papillae.
Apothecia with excipulum containing algae, with lateral verrucose protuberances. Hymenium 100-130 $\mu \mathrm{m}$ high. Ascospores not observed (immature apothecia).

ITS2 barcode. - AACGCCATGTCGCTCGGCGG.

Chemistry. - Gyrophoric acid, congyrophoric acid, and occasionally pseudocyphellarin A.

Distribution. - So far only known from Taiwan.

Additional specimens examined. - Refer to Appendix 2.

Dendriscosticta platyphylloides (Nyl.) Moncada \& Lücking in Lichenologist 45: 223. 2013 三 Sticta platyphylloides Nyl. in Bull. Soc. Bot. France 34: 22. 1887 - Type: China. Yunnan: "ad Quercus in faucibus Hoang-se-ia-keou, prope Tapin-tze", alt. $1800 \mathrm{~m}, 11$ May 1885, P.J.M. Delavay 1607 (H-NYL No. 33655 [H barcode H9505982]!). ?= Sticta henryana Müll.Arg. in Flora 74:374. 1891-Type: China. Hubei Province, A. Henry 6932 (G barcode G00295320!).

Fig. 10C,D

Short description. - Thallus macrofoliose, primarily associated with a green alga. Upper surface apparently scabrous or pruinose, without phyllidia. Lower surface cream to beige-colored, paler towards margins. Medulla $\mathrm{KC}-$.

ITS2 barcode. - $\mathrm{C}(\mathrm{G})$ CGCTGGGTGTTGGGCCGRCG TCCCCCG.

Chemistry. - Pseudocyphellarin A usually present.

Distribution. - Reported from Bhutan (Søchting, 1999), China (Chen \& al., 1994; Li \& al., 2013), India (Joshi \& al., 2016), Nepal (Devkota \& al., 2017), Sri Lanka (Weerakoon, 2015; Weerakoon \& Aptroot, 2014), Thailand (Wolseley \& al., 2002; Buaruang \& al., 2017) and Vietnam (Nguyen \& al., 2019). These records need to be confirmed by DNA sequencing owing to the paucity of unambiguous morphological characters in the genus. Based on the results presented here, this species is confirmed from southern China (Sichuan, Xinzang, Yunnan).

Comments. - A single collection is mentioned in the original description of this species (Nylander in Hue, 1887) and can thus be considered as the holotype collection. Dendriscosticta platyphylloides can be distinguished from closely related species (i.e., D. gelida, D. oroborealis, D. wrightii and D. yatabeana) by its paler lower surface, usually ranging from whitish to beige.

Sticta henryana is a likely synonymous species reported from India (Kumar, 2000) and Nepal (Devkota \& al., 2017). The type collection of $S$. henryana comes from Hubei Province in central China, from which no other specimen is available. The type material was examined in $\mathrm{G}$ and it undoubtedly belongs to Dendriscosticta and, as it lacks gyrophoric acid, to the $D$. wrightii clade. While the specimen could not morphologically be linked to any particular accepted species, this taxon might be synonymous with another species within this clade owing to the paucity of unambiguous morphological characters available to distinguish these closely related species. TLC yielded pseudocyphellarin A, a chemical feature most often encountered in the species $D$. platyphylloides. For this reason, we believe that $S$. henryana is most likely a synonym of $D$. platyphylloides.

Additional specimens examined. - Refer to Appendix 2. 
Dendriscosticta praetextata (Räsänen) Moncada \& Lücking in Lichenologist 45: 223. 2013 ESticta platyphylla var. praetextata Räsänen in Suom. Elain-ja Kasvit. Seuran Van. Tiedon. 6: 84. 1952 =Sticta praetextata (Räsänen) D.D. Awasthi in Biol. Mem. 7: 185. 1982 - Holotype: India. Uttarakhand: NW Himalaya, Almora, Dhakuri Ridges en route to Pindari Glacier, $9500 \mathrm{ft}$., corticolous, May 1950, D.D. Awasthi 109 \& A.M. Awasthi (H!; isotype: LWG n.v.). Fig. 10E

Short description. - Thallus macrofoliose with abundant marginal phyllidia, similar to Dendriscosticta phyllidiata, differing in the absence of congyrophoric acid.

ITS2 barcode. - GGCCGACGTYCCGTTC.

Chemistry. - Gyrophoric acid and occasionally pseudocyphellarin A.

Distribution. - Reported from Bhutan (Søchting, 1999), China (Chen \& al., 1994), India (Kumar, 2000; Joshi \& al., 2016), Japan (Takahashi \& al., 2012; Ohmura \& Kashiwadani, 2018) and Nepal (Devkota \& al., 2017). Based on the results presented here, this species is confirmed from northern India (Uttarakhand) and southern China (Xinzang, Yunnan).

Comments. - A recent collection from near the type locality (Bajpai \& Upreti 12-011438, LG) has been successfully sequenced.

Additional specimens examined. - Refer to Appendix 2.

Dendriscosticta wrightii (Tuck.) Moncada \& Lücking in Lichenologist 45: 224. 2013 三 Sticta wrightii Tuck. in Amer. J. Sci. Arts 28: 204. 1859 三 Ricasolia wrightii (Tuck.) Nyl., Syn. Meth. Lich. 1: 366. 1860 - Lectotype (designated by Asahina in J. Jap. Bot. 36: 225. 1961): Japan. Hokkaido: Hakodadi, mountain sides, on beech trunks, C. Wright s.n. (FH barcode 00213370 a \& a'!; isolectotype: US barcode 00432750!) - Epitype designated here [MBT10000071]: Japan. Hokkaido: Kameda District, Nanae, along the road towards Mt. Yokotsu, $41.917848 \mathrm{~N}, 140.764491 \mathrm{E}, 883 \mathrm{~m}$, in deciduous forest including Acer, Quercus, and Sorbus, with dense bamboo undergrowth, on Fagus, 16 Aug. 2019, A. Simon \& al. 638 (TNS barcode TNS-L-130566!).

?=Sticta miyoshiana Müll.Arg. in Flora 74: 111. 1891 Type: Japan. Uzen, corticolous, M. Miyoshi s.n. (G barcode G00052580 n.v.).

?= Sticta yasudae Vain. in Bot. Mag. (Tokyo) 35: 64. 1921 Type: Japan. Inaba Province, Mount Nagi, corticolous on tree, 31 Oct 1914, M. Nakaji s.n., hb. A. Yasuda (holotype: unlocated; isotype: TNS n.v.).

Fig. 11A

Description. - Photobiont green (presumably Dictyochloropsis s.1.). Stipe absent. Thallus foliose, epiphytic, radially plicate-rugose, orbicular in outline, up to $15 \mathrm{~cm}$ in diam., coriaceous and tough, rather thick, branching anisotomous or pleurotomous. Lobes somewhat plane or undulate, flabellate or ligulate, imbricate, longer than wide, adnate, with plane or involute apices; margins sinuose; lobe internodes to $20 \mathrm{~mm}$ long. Upper surface smooth or weakly rugose, dark green when fresh, turning pale brown in herbarium, opaque, with margin concolorous; surface scabrose, or seemingly pruinose, due to the presence of cortical hairs, especially along margins. Cilia absent. Apothecia either absent, or if present usually abundant, cup-shaped, up to $5 \mathrm{~mm}$ in diam., laminal, dispersed, pedicellate, with pronounced basal invagination, with glossy, orange to brown disk. Apothecia absent. Medulla compact, white, $\mathrm{K}-$ (cortex occasionally $\mathrm{K}+$ yellow), $\mathrm{C}-, \mathrm{KC}-, \mathrm{P}-$. Lower surface smooth, brown-colored. Lower tomentum dense throughout, patchily thick and thin, spongy, soft or rough, concolorous with lower surface. Rhizines sparse, dispersed, fasciculate or squarrose, cream to brown-colored, up to $2 \mathrm{~mm}$ long. Cyphelloid pores abundant, 21-40 per $\mathrm{cm}^{2}$ (central) to 41-60 per $\mathrm{cm}^{2}$ (marginal), dispersed, rounded to irregular, urceolate with wide pore, immersed, below level of tomentum, with cream to brown-colored margins; pore to $2 \mathrm{~mm}$ in diam.; basal membrane pruinose, white. Pycnidia not observed.

Upper cortex paraplectenchymatous, 50-75 $\mu \mathrm{m}$ thick, homogeneous, consisting of 7-8 cell layers with cells $6-12 \mu \mathrm{m}$ diam., their lumina round-isodiametric. Photobiont layer 35$65 \mu \mathrm{m}$ thick, its cells 5-8 $\mu \mathrm{m}$ diam. Medulla $250-450 \mu \mathrm{m}$ thick, its hyphae $3.5-4.5 \mu \mathrm{m}$ broad, without crystals. Lower cortex paraplectenchymatous, $20-40 \mu \mathrm{m}$ thick, with 4 or 5 cell layers; cells 3.5-5.0 $\mu \mathrm{m}$ diam. Hairs of lower tomentum in fascicles of 6-12 hyphae with intertwined apices. Cephalodia usually present (internal). Cyphelloid pores with cells of basal membrane polygonal and entangled, 3-5 $\mu \mathrm{m}$ wide, without papillae.

Apothecia with excipulum containing algae, with lateral verrucose protuberances. Hymenium 120-200 $\mu \mathrm{m}$ high. Ascospores 1-3-septate, acicular, 40-65 × 3-5 $\mu \mathrm{m}$, hyaline.

ITS2 barcode - CCGCGCTGGGTGTTGGGCC GGCGTCCTCCCGG.

Chemistry. - No chemistry detected by TLC, but occasionally $\mathrm{K}+$ yellow (traces of pseudocyphellarin A).

Distribution. - Dendriscosticta wrightii is an epiphytic lichen of humid temperate and subtropical regions. As diagnosed here, it is so far restricted to Hokkaido (Japan; e.g, Ohmura \& Kashiwadani, 2018) and South Korea (e.g., Kashiwadani \& al., 2002; Hur \& al., 2004). Earlier reports from Mongolia (Biazrov, 2013), Russia (Fadeeva, 2005, 2009; Makryi, 2008; Karasev \& Selivanov, 2014; Kuznetsova \& Skazina, 2010), and Thailand (Wolseley \& al., 2002; Buaruang $\&$ al., 2017) likely represent another species. The records from northwestern North America refer to Dendriscosticta gelida or D. oroborealis; those from continental Europe (e.g., Karelia and Germany) probably belong to D. gelida, and those from India and China either to D. platyphylloides or D. yatabeana.

Comments. - Dendriscosticta wrightii had also been mentioned from Cameroon (Orock \& al., 2012) and the corresponding material was examined, but no exploitable DNA could be obtained. However, it is unlikely that the material belongs to Dendriscosticta as it consists of a foliose cyanolichen.

Dendriscosticta wrightii has been used in traditional medicine in China, such as for treating kidney inflammation or for 
its spleen-tonifying action (Ding, 2010; Wang \& Qian, 2013). However, this species may have been easily confused with D. platyphylloides, which appears to be the most common species in southern China.

Nomenclatural notes. - To clarify the application of the widely used name Dendriscosticta wrightii, we propose a sequenced epitype that is morphologically and geographically consistent with the lectotype (FH). As already noted by Asahina (1961) the original material was collected on Hokkaido, Japan and consists of four thalli representing two species: the largest thallus and one of the smaller ones belong to D. wrightii s.str. (accordingly, with the characters mentioned in the original protologue), whereas the two remaining smaller thalli belong to another species in the D. praetextata clade (referred to as "Sticta insinuans Nyl." by Asahina). Thus, as the original type consisted of heterogeneous elements Asahina (1961) recognized two thallus fragments in this collection as the lectotype (labelled a and a' in the publication). The type specimen is, however, ambiguous, in terms of its interpretative value as $D$. wrightii is phenotypically indistinguishable from D. yatabeana with which it is sympatric in Japan and South Korea. The two species are confidently distinguished by their ITS2 barcode. Since sequences could not be obtained for the lectotype, which is therefore demonstrably ambiguous, an epitype (associated with sequence data for ITS2) is herein designated to serve an interpretative type. The epitype was collected in Kameda Peninsula, Hokkaido, Japan, a region that includes the type locality, "Hakodadi, Japan". This interpretative type represents the traditional concept of $D$. wrightii and fits the original type.

The type locality, Hakodadi (= Hakodate; Tuckerman, 1859), is a major city in southern Hokkaido, Japan. We explored the wooded hill behind the city that forms a prominent part of the Kameda Peninsula ("Mount Hakodate"). This locality is now highly disturbed, and extensively planted with Cryptomeria japonica. No lobarioid lichens were observed. We therefore explored other localities in the Kameda Peninsula and located a healthy population of Dendriscosticta that fits the original description and material collected by Wright.

Sticta miyoshiana Müll.Arg. and S. yasudae Vain. have been reduced to synonymy with $S$. wrightii by Asahina (1961) and we propose not to resurrect these two epithets. Indeed, epitypification with fresh and sequenced material would be needed to do so. Sticta miyoshiana was collected in the "Uzen province" in the Yamagata Prefecture (northern part of Honshu), whereas S. yasudae was collected in the Tottori Prefecture (central part of Honshu, West of Kyoto). The synonymy of the two species with $D$. wrightii (or D. yatabeana) is thus not currently confirmed and could be challenged by collections with exploitable DNA from these two localities.

Additional specimens examined. - Refer to Appendix 2.

Dendriscosticta yatabeana (Müll.Arg.) Ant.Simon, Goffinet \& Sérus., comb. nov. [MB 835914] $\equiv$ Sticta yatabeana Müll.Arg. in Flora 74: 111. 1891 ERicasolia yatabeana (Müll.Arg.) Stizenb. in Flora 81: 112. 1895 三Lobaria yatabeana (Müll.Arg.) Zahlbr., Cat. Lich. Univ. 3: 320. 1925 - Type: Japan. Honshu: Mount Ontake, 1890, F. Miyoshi 118 (G barcode G00052578!; isotype: TNS n.v.) - Epitype designated here [MBT10000072]: Japan. Honshu: Nagano Prefecture, Kiso-gun, Otaki, Hakkaisan, vicinity of Mount Ontake, along Road 256 and Omata River, 35.858436N, 137.532966E, $1042 \mathrm{~m}$, in mixedwood forest with dense bamboo undergrowth, on Ulmus, 21 Aug 2019, A. Simon 670 \& E. Sérusiaux (TNS barcode TNS-L130567!).

Fig. 11B-D

Description. - Chloromorph: photobiont green (presumably Dictyochloropsis s.1.). Stipe absent. Thallus foliose, epiphytic, rarely saxicolous, radially plicate-rugose, orbicular in outline, up to $15 \mathrm{~cm}$ in diam., coriaceous and resistant, rather thick, branching anisotomous or pleurotomous. Lobes somewhat involute, flabellate or ligulate, imbricate, approximately as long as wide, adnate or ascending, with plane or involute apices; margins sinuose, slightly thickened; lobe internodes 3-20 mm long. Upper surface smooth or weakly rugose, dark green when fresh, turning brown in herbarium, opaque, with margin concolorous; surface scabrose, or seemingly pruinose, due to the presence of cortical hairs, especially in marginal areas of lobes. Cilia absent. Apothecia either absent, or if present usually abundant, cup-shaped, up to $5 \mathrm{~mm}$ in diam., dispersed, pedicellate, with pronounced basal invagination, with glossy, orange to brown disk. Apothecia absent. Medulla compact, white, $\mathrm{K}-$ (cortex occasionally $\mathrm{K}+$ yellow), $\mathrm{C}-, \mathrm{KC}-$, $\mathrm{P}-$. Lower surface smooth, cream to brown-colored, clearer towards margins. Lower tomentum irregular, patchily absent, spongy, soft or rough, concolorous with lower surface. Rhizines sparse, dispersed, fasciculate or tomentose, cream to browncolored, up to $6 \mathrm{~mm}$ long. Cyphelloid pores abundant, 21-40 per $\mathrm{cm}^{2}$ (central) to $41-60$ per $\mathrm{cm}^{2}$ (marginal), dispersed, rounded to irregular, urceolate with wide pore, immersed, below level of tomentum, with cream to brown-colored margins; pore to $1(-2) \mathrm{mm}$ in diam.; basal membrane pruinose, white. Pycnidia occasionally present, immersed, with black ostiole.

Upper cortex paraplectenchymatous, $40-60 \mu \mathrm{m}$ thick, homogeneous, consisting of 7 or 8 cell layers with cells $5-8 \mu \mathrm{m}$ diam., their lumina round-isodiametric. Photobiont layer 35$45 \mu \mathrm{m}$ thick, its cells 4.5-7.5 $\mu \mathrm{m}$ diam. Medulla $250-500 \mu \mathrm{m}$ thick, its hyphae 3.5-4.5 $\mu \mathrm{m}$ broad, without crystals. Lower cortex paraplectenchymatous, 25-35 $\mu$ m thick, with 4 or 5 cell layers; cells 3.5-6.5 $\mu \mathrm{m}$ diam. Hairs of lower tomentum in fascicles of 6-12 hyphae with intertwined apices. Cephalodia usually present (internal). Cyphelloid pores with cells of basal membrane polygonal and entangled, 3-5 $\mu \mathrm{m}$ wide, without papillae.

Apothecia with excipulum containing algae, with lateral verrucose protuberances. Hymenium 130-190 $\mu \mathrm{m}$ high. Ascospores 1-3-septate, acicular, 50-80 × 3.5-5 $\mu \mathrm{m}$, hyaline.

Cyanomorph: photobiont blue-green (Nostoc). Thallus dendriscocauloid (fruticose).

ITS2 barcode. - CGCGCTGGGTGTTGGGCCGGCGT CCC(C)TCCG.

Chemistry. - No substances detected by TLC. 
Distribution. - Reported from Japan (Yoshimura, 1974), Russia (Makryi, 2008) and South Korea (Jayalal \& al., 2014). Based on the results presented here, this species is confirmed from southern China (Sichuan, Xizang, Yunnan), Japan, South Korea, and Taiwan.

Nomenclatural notes. - A single collection is mentioned in the original description of this species and can thus be considered as the holotype collection. The epitype selected for this epithet comes from the type locality on Mount Ontake (Japan, Honshu); it morphologically fits the original type and description, and was successfully sequenced. The decision to epitypify Dendriscosticta yatabeana followed the same rationale as detailed for $D$. wrightii hereabove. These two partially sympatric species cannot be distinguished phenotypically, that is based on morphological or chemical traits, and identification currently relies on the ITS2 barcode. Since no molecular data could be obtained for the type specimen of this taxon and that the type specimen is thus demonstrably ambiguous, an epitype (associated with sequence data for the internal transcribed spacer 2) is herein designated to serve as an interpretative type. The epitype's geographical provenance (Japan, Honshu, Mount Ontake) is in full agreement with the locality cited in Johannes Müller Argoviensis's protologue.

Additional specimens examined. - Refer to Appendix 2.

\section{AUTHOR CONTRIBUTIONS}

AS designed the study, carried out fieldwork, generated the molecular data, performed the phylogenetic analyses, prepared the taxonomic treatment, and drafted the study. BG, NM, and ES carried out fieldwork, assisted in taxonomic treatment, and advised on all aspects of the research. LSW and NVS carried out fieldwork and provided voucher specimens. TS carried out fieldwork, contributed to the taxonomic treatment and conducted scanning electron microscopy. TG provided voucher specimens and critically contributed to the discussion. TP and NS coordinated field research. BM and RL contributed to the interpretation of the results and the nomenclature to be adopted. The submitted draft has been reviewed and accepted by all the authors. - AS, https://orcid.org/0000-0002-7766-5751; BG, https://orcid.org/00000002-2754-3895; TS, https://orcid.org/0000-0002-9855-4591; TP, https://orcid.org/0000-0003-2215-4724; NVS, https://orcid.org/00000002-0692-8796; BM, https://orcid.org/0000-0001-9984-2918; RL, https://orcid.org/0000-0002-3431-4636; NM, https://orcid.org/00000001-5409-9518; ES, https://orcid.org/0000-0002-0456-0131

\section{- ACKNOWLEDGEMENTS}

AS acknowledges financial support from FRIA, a grant of the Fonds de la Recherche Scientifique - FNRS (F.R.S.-FNRS). This study was also supported by NSF grant DEB-1354631 to BG and additional intramural funds. We are grateful to the herbarium curators of $\mathrm{FH}, \mathrm{G}, \mathrm{H}$, KoLRI, LE, TNS, UBC, and US for arranging for loans of material or visits. For collections stored in S, Mats Wedin could confirm that these were unfortunately inaccessible for the time being. The Chinese material was supported by grants from the National Natural Science Foundation of China (31970022, 31670028) and the Second Tibetan Plateau Scientific Expedition and Research Program (STEP; 2019QZKK0503). This work was carried out within the framework of a State Assignment of the Institute of Biology of Komi Science Center, Ural Branch, Russian
Academy of Sciences. The field trip in Japan was funded by FNRS grant "Lichen genomics and climate" (CDR J.0147.19). We thank Shuzo Oita (School of Plant Sciences, University of Arizona) and Prof. Yoshitaka Uchida (University of Hokkaido) for their help in organizing the logistics of the trip and gathering all the collecting permits in Japan, as well as Prof. Yoshitaka Uchida and all his students for help and assistance in the field. We also thank Prof. Karibu Fukuzawa (University of Hokkaido) and the Nakagawa Experimental Forest, and Prof. Ryunosuke Tateno (Kyoto University) and the Shibecha research forest for welcoming us and for their assistance with the field studies in Hokkaido. We thank the Ministry of the Environment, the Ministry of Culture of Japan and the Nakagawa city council for processing and delivering the collection permits. The following friends and colleagues are warmly thanked for providing material or assisting with fieldwork: Rajesh Bajpai, Paula Bartemucci, Alexander Borovlev, Romain Darnajoux, Thibaut Dethier, Karen Dillman, Spencer Goyette, Jae-Seoun Hur, Yoshihito Ohmura, Christine Partoune, Craig Pettitt, Gulnara Tagirdzhanova, Tor Tønsberg, and Dalip K. Upreti. We further thank Laurent Gohy and Dinah Parker for technical assistance in the molecular laboratory at the University of Liège and the University of Connecticut, respectively. An earlier version of this article was included in the Ph.D. dissertation of AS.

\section{口 LITERATURE CITED}

Altermann, S., Leavitt, S.D. \& Goward, T. 2016. Tidying up the genus Letharia: Introducing L. lupina sp. nov. and a new circumscription for L. columbiana (Nutt.) Thoms. Lichenologist 48: 423-439. https://doi.org/10.1017/S0024282916000396

Altschul, S.F., Warren, G., Webb, M., Myers, E.W. \& Lipman, D.J. 1990. Basic local alignment search tool. J. Molec. Biol. 215: 403410. https://doi.org/10.1016/S0022-2836(05)80360-2

Altschul, S.F., Madden, T.L., Schäffer, A.A., Zhang, J., Zhang, Z., Miller, W. \& Lipman, D.J. 1997. Gapped BLAST and PSIBLAST: A new generation of protein database search programs. Nucl. Acids Res. 25: 3389-3402. https://doi.org/10.1093/nar/25. 17.3389

Armaleo, D. \& Clerc, P. 1991. Lichen chimeras: DNA analysis suggests that one fungus forms two morphotypes. Exp. Mycol. 15: 1-10. https://doi.org/10.1016/0147-5975(91)90002-U

Asahina, Y. 1961. Lichenologische Notizen (180-181). J. Jap. Bot. 36: 225-228.

Biazrov, L.G. 2013. Checklist of the Mongolian lichens, version 8 . Available at http://www.sevin.ru/laboratories_eng/biazrov_mong. html (last accessed Nov 2020).

Blum, O.B., Dombroskaya, A.V., Inashvili, C.N., Piteran, A.V., Roms, E.G. \& Savicz, V.P. 1975. Opredelitel' Lishaĭnikov SSSR, vol. 3, Caliciaceae-Gyalectaceae [Handbook of the lichens of the U.S.S.R., vol. 3, Caliciaceae - Gyalectaceae]. Leningrad: The Academy of Sciences of the U.S.S.R.

Bouckaert, R. \& Heled, J. 2014. DensiTree 2: Seeing trees through the forest. bioRxiv. https://doi.org/10.1101/012401

Bouckaert, R., Heled, J., Kühnert, D., Vaughan, T., Wu, C.-H., Xie, D., Suchard, M.A., Rambaut, A. \& Drummond, A.J. 2014. BEAST 2: A software platform for Bayesian evolutionary analysis. PLoS Comput. Biol. 10: e1003537. https://doi.org/10.1371/journal. pcbi. 1003537

Buaruang, K., Boonpragob, K., Mongkolsuk, P., Sangvichien, E., Vongshewarat, K., Polyiam, W., Rangsiruji, A., Saipunkaew, W., Naksuwankul, K., Kalb, J., Parnmen, S., Kraichak, E., Phraphuchamnong, P., Meesim, S., Luangsuphabool, T., Nirongbut, P., Poengsungnoen, V., Duangphui, N., Sodamuk, M., Phokaeo, S., Molsil, M., Aptroot, A., Kalb, K., Luecking, R. \& Lumbsch, T. 2017. A new checklist of lichenized fungi occurring in Thailand. MycoKeys 23: 1-91. https://doi.org/ $10.3897 /$ mycokeys.23.12666 
Budaeva, S.E. 2014. Redkie i reliktovye lishajniki severo-vostochnogo i vostochnogo poberezh'ja ozera Bajkal i gornyh hrebtov Burjatii [Rare and relict lichens of the north-easten and eastern coast of Lake Baikal and of the mountain ranges of Buryatia]. Pp. 43-48 in: Lihenologija V Rossii: Aktual'nye Problemy i Perspektivy Issledovanij [Second International Conference "Lichenology" in Russia: Problems and Perspectives]. Saint Petersburg: The Russian Academy of Sciences. [in Russian]

Camargo, A., Avila, L.J., Morando, M. \& Sites, J.W. 2012. Accuracy and precision of species trees: Effects of locus, individual, and base-pair sampling on inference of species trees in lizards of the Liolaemus darwinii group (Squamata, Liolaemidae). Syst. Biol. 61: 272-288. https://doi.org/10.1093/sysbio/syr105

Ceballos, G. \& Ehrlich, P.R. 2018. The misunderstood sixth mass extinction. Science 360: 1080-1081. https://doi.org/10.1126/science. aau0191

Ceballos, G., Ehrlich, P.R., Barnosky, A.D., García, A., Pringle, R.M. \& Palmer, T.M. 2015. Accelerated modern human-induced species losses: Entering the sixth mass extinction. Sci. Adv. 1: e1400253. https://doi.org/10.1126/sciadv.1400253

Chen, J., Wang, Z. \& Wang, L. 1994. The lichen genus Sticta from Yunnan of China. Acta Mycol. Sin. 13: 29-33.

Cornejo, C. \& Scheidegger, C. 2015. Multi-gene phylogeny of the genus Lobaria: Evidence of species-pair and allopatric cryptic speciation in East Asia. Amer. J. Bot. 102: 2058-2073. https:// doi.org/10.3732/ajb.1500207

Crespo, A. \& Lumbsch, H.T. 2010. Cryptic species in lichen-forming fungi. IMA Fungus 1: 167-170. https://doi.org/10.5598/imafungus. 2010.01.02.09

Cubero, O.F., Crespo, A., Fatehi, J. \& Bridge, P.D. 1999. DNA extraction and PCR amplification method suitable for fresh, herbarium-stored, lichenized, and other fungi. Pl. Syst. Evol. 216: 243-249. https://doi.org/10.1007/BF01084401

Darriba, D., Taboada, G.L., Doallo, R. \& Posada, D. 2012. jModelTest 2: More models, new heuristics and parallel computing. Nature, Meth. 9: 772. https://doi.org/10.1038/nmeth.2109

De Queiroz, K. 2007. Species concepts and species delimitation. Syst. Biol. 56: 879-886. https://doi.org/10.1080/10635150701701083

DellaSala, D.A. (ed.) 2011. Temperate and boreal rainforests of the world: Ecology and conservation. Washington, D.C.: Island Press.

Dettman, J.R., Jacobson, D.J. \& Taylor, J.W. 2003. A multilocus genealogical approach to phylogenetic species recognition in the model eukaryote Neurospora. Evolution 57: 2703-2720. https:// doi.org/10.1111/j.0014-3820.2003.tb01514.x

Devkota, S., Keller, C., Olley, L., Werth, S., Chaudhary, R.P. \& Scheidegger, C. 2017. Distribution and national conservation status of the lichen family Lobariaceae (Peltigerales): From subtropical luxuriant forests to the alpine scrub of Nepal Himalaya. Mycosphere 8: 630-648. https://doi.org/10.5943/mycosphere/8/ $4 / 10$

Ding, H. 2010. Zhong wai yao yong bai zi zhi wu zi yuan zhi yao [A summary of Chinese and foreign medicinal spore-bearing plant resources]. Guiyang: Guizhou Science and Technology Press. [in Chinese]

Elix, J.A. 2014. A catalogue of standardized chromatographic data and biosynthetic relationships for lichen substances. Canberra: published by the author.

Elix, J.A. \& Lajide, L. 1984. Synthesis of the lichen depsides pseudocyphellarin A and B. Austral. J. Chem. 37: 2153-2157. https://doi. org/10.1071/CH9842153

Esslinger, T.L. 2019. A cumulative checklist for the lichen-forming, lichenicolous and allied fungi of the continental United States and Canada, version 23. Opusc. Philolichenum 18: 102-378.

Fadeeva, M.A. 2005. Nemoral'nye vidy vo flore lishajnikov karelii $=$ Nemoral species in the lichen flora of Karelia. Pp. 255-265 in: Biogeografiâ Karelii: Trudy KarNC RAN. Seriâ "Biologiâ" = Biogeography of Karelia: Proceedings of KarRC RAS. Series “Biology”, vol. 7. Petrozavodsk: KarRC RAS. [in Russian with English abstract]

Fadeeva, T.L. 2009. Izmenenija v spiske lishajnikov v novoj redakcii Krasnoj knigi respubliki Karelija = Changes in the lichens list in the new edition of the Red Data Book of Republic of Karelia. Trans. Karelian Res. Centre Russ. Acad. Sci. 2009(1): 51-56. [in Russian with English abstract]

Fujisawa, T. \& Barraclough, T.G. 2013. Delimiting species using single-locus data and the generalized mixed yule coalescent approach: A revised method and evaluation on simulated data sets. Syst. Biol. 62: 707-724. https://doi.org/10.1093/sysbio/syt033

Galloway, D.J. 1983. New taxa in the New Zealand lichen flora. New Zealand J. Bot. 21: 191-199.

Galloway, D.J. 2001. Dendriscocaulon. Pp. 38-39 in: McCarthy, P.M. (ed.), Flora of Australia, vol. 58A, Lichens, vol. 3. Melbourne: ABRS/CSIRO.

Galloway, D.J. 2015. Contributions to a history of New Zealand lichenology 5*. James Murray (1923-1961). Phytotaxa 198: 1-67. https://doi.org/10.11646/phytotaxa.198.1.1

Galloway, D.J. \& Elix, J.A. 2013. Reinstatement of Crocodia Link (Lobariaceae: Ascomycota) for five species formerly included in Pseudocyphellaria Vain. Australas. Lichenol. 72: 32-42.

Gardes, M. \& Bruns, T.D. 1993. ITS primers with enhanced specificity for basidiomycetes - Application to the identification of mycorrhizae and rusts. Molec. Ecol. 2: 113-118. https://doi.org/ 10.1111/j.1365-294X.1993.tb00005.x

Goward, T. 1994. Notes on oldgrowth-dependent epiphytic macrolichens in inland British Columbia, Canada. Acta Bot. Fenn. 150: 31-38.

Goward, T. \& Arsenault, A. 2000. Cyanolichens and conifers: Implications for global conservation. Forest Snow Landscape Res. 75: 303-318.

Goward, T., McCune, B. \& Meidinger, D. 1994. The lichens of British Columbia: Illustrated keys, part 1, Foliose and squamulose species. Special Report Series, vol. 8. Victoria, B.C.: Ministry of Forests.

Goward, T., Breuss, O., Ryan, B., McCune, B., Sipman, H. \& Scheidegger, C. 1996. Notes on the lichens and allied fungi of British Columbia. III. Bryologist 99: 439. https://doi.org/10. 2307/3244108

Heiðmarsson, S.J., Mattsson, E., Moberg, R., Nordin, A., Santesson, R. \& Tibell, L. 1997. Classification of lichen photomorphs. Taxon 46: 519-520. https://doi.org/10.2307/1224392

Heled, J. \& Drummond, A.J. 2010. Bayesian inference of species trees from multilocus data. Molec. Biol. Evol. 27: 570-580. https://doi.org/10.1093/molbev/msp274

Hofstetter, V., Buyck, B., Eyssartier, G., Schnee, S. \& Gindro, K. 2019. The unbearable lightness of sequenced-based identification. Fungal Diversity 96: 243-284. https://doi.org/10.1007/s13225-019-00428-3

Högnabba, F., Stenroos, S. \& Thell, A. 2009. Phylogenetic relationship and evolution of photobiont associations in the Lobariaceae (Peltigerales, Lecanoromycetes, Ascomycota). Pp. 157-187 in: Thell, A., Seaward, M.R.D. \& Feuerer, T. (eds.), Diversity of lichenology: Anniversary volume. Bibliotheca Lichenologica 100. Berlin \& Stuttgart: J. Cramer in der Gebrüder Borntraeger Verlagsbuchhandlung.

Hue, A. 1887. Lichenes Yunnanensses a Claro Delavay anno 1885 collectos, et quorum novae species a celeb. W. Nylander descriptae fuerunt. Bull. Soc. Bot. France 34: 16-24.

Hur, J.S., Harada, H., Oh, S.O., Lim, K.M., Kang, E.S., Lee, S.M., Kahng, H.Y., Kim, H.W., Jung, J.S. \& Koh, Y.J. 2004. Distribution of lichen flora on South Korea. J. Microbiol. 42: 163-167.

Jayalal, U., Joshi, S., Oh, S.O., Kim, J.A., Koh, Y.J., Crişan, F. \& Hur, J.S. 2014. The lichen genus Sticta in South Korea. Mycobiology 42: 6-11. https://doi.org/10.5941/MYCO.2014.42.1.6

Jørgensen, P.M. 1996. On the nomenclature of lichen phototypes. Taxon 45: 663-664. https://doi.org/10.2307/1224250

Jørgensen, P.M. 1998. What shall we do with the blue-green counterparts? Lichenologist 30: 351-356. https://doi.org/10.1006/lich.1998.0146 
Joshi, S., Upreti, D.K. \& Das, P. 2016. Lichen diversity assessment in Pindari Glacier Valley of Uttarakhand, India. Geophytology 41: 24-41.

Jukes, T.H. \& Cantor, C.R. 1969. Evolution of protein molecules. Pp. 21-132 in: Munro, H.N. (ed), Mammalian protein metabolism. New York: Academic Press.

Karasev, K.A. \& Selivanov, A.E. 2014. Protected lichens Sticta wrightii Tuck. in Perm region. Modern Probl. Sci. Educ. 2014 (5): art. 614. https://doi.org/10.17513/spno.2014.5

Kashiwadani, H., Moon, K.-H., Inoue, M., Thor, G. \& Kim, Y.S. 2002. Lichens of the Cheju Island, Republic of Korea I. The Macrolichens. Monogr. Natl. Sci. Mus. (Tokyo) 22: 115-135.

Katoh, K. 2002. MAFFT: A novel method for rapid multiple sequence alignment based on fast Fourier transform. Nucl. Acids Res. 30: 3059-3066. https://doi.org/10.1093/nar/gkf436

Katoh, K., Asimenos, G. \& Toh, H. 2009. Multiple alignment of DNA sequences with MAFFT. Pp. 39-64 in: Posada, D. (ed.), Bioinformatics for DNA sequence analysis. New York: Humana Press. https://doi.org/10.1007/978-1-59745-251-9_3

Kauff, F. \& Lutzoni, F. 2002. Phylogeny of the Gyalectales and Ostropales (Ascomycota, Fungi): Among and within order relationships based on nuclear ribosomal RNA small and large subunits. Molec. Phylogen. Evol. 25: 138-156. https://doi.org/10. 1016/S1055-7903(02)00214-2

Kauff, F. \& Lutzoni, F. 2003. Compat.py - A program to detect topological conflict between supported clades in phylogenetic trees. Available on http://lutzonilab.org/downloadable-programs/

Kirk, P.M., Cannon, P.F., Minter, D.W. \& Stalpers, J.A. (eds.) 2008. Ainsworth and Bisby's Dictionary of the fungi, 10th ed. Wallingford: CABI. https://doi.org/10.1079/9780851998268.0000

Kolbert, E. 2014. The sixth extinction: An unnatural history. New York: Henry Holt.

Kraichak, E., Huang, J.P., Nelsen, M., Leavitt, S.D. \& Lumbsch, H.T. 2018. A revised classification of orders and families in the two major subclasses of Lecanoromycetes (Ascomycota) based on a temporal approach. Bot. J. Linn. Soc. 188: 233-249. https://doi. org/10.1093/botlinnean/boy060

Krempelhuber, A. von 1861. Die Lichenen-Flora Bayerns; oder Aufzählung der bisher in Bayern (diesseits des Rheins) aufgefundenen Lichenen mit besonderer Berücksichtigung der verticalen Verbreitung dieser Gewächse in den Alpen. Denkschr. Königl.Baier. Bot. Ges. Regensburg 4: 1-317.

Krempelhuber, A. von 1862. Ueber das Vorkommen von Ricasolia Wrightii (Tuckerm.) Nyl. in den Alpen Bayerns. Flora 45: 441-444.

Krog, H. 1968. The macrolichens of Alaska. Norsk Polarinst. Skr. 144: $1-180$.

Kumar, M. 2000. Lichen (Macrolichen) flora of Kerala part of Western Ghats. Research Report 194. Peechi, Thrissur: Kerala Forest Research Institute.

Kuznetsova, E.S. \& Skazina, M.A. 2010. Kizucheniju lishajnikov Kostromskoj oblasti [Contribution to the lichen studying of the Kostroma Region]. Novosti Sist. Nizsh. Rast. 44: 200-209. [in Russian with English abstract]

Lanfear, R., Calcott, B., Ho, S.Y.W. \& Guindon, S. 2012. PartitionFinder: Combined selection of partitioning schemes and substitution models for phylogenetic analyses. Molec. Biol. Evol. 29: 1695-1701. https://doi.org/10.1093/molbev/mss020

Lanfear, R., Frandsen, P.B., Wright, A.M., Senfeld, T. \& Calcott, B. 2016. PartitionFinder 2: New methods for selecting partitioned models of evolution for molecular and morphological phylogenetic analyses. Molec. Biol. Evol. 34: 772-773. https://doi.org/ 10.1093/molbev/msw260

Leavitt, S.D., Esslinger, T.L., Divakar, P.K. \& Lumbsch, H.T. 2012. Miocene divergence, phenotypically cryptic lineages, and contrasting distribution patterns in common lichen-forming fungi (Ascomycota: Parmeliaceae). Biol. J. Linn. Soc. 107: 920-937. https://doi.org/10.1111/j.1095-8312.2012.01978.x
Leavitt, S.D., Moreau, C.S. \& Lumbsch, H.T. 2015. The dynamic discipline of species de limitation: Progress toward effectively recognizing species boundaries in natural populations. Pp. 11-44 in: Upreti, D.K., Divakar, P.K., Shukla, V.\& Bajpai, R. (eds.), Recent advances in lichenology, vol. 2. New Delhi: Springer.

Lendemer, J.C. 2020. Epitypes are forever: Best practices for an increasingly misused nomenclatural action. Taxon 69: 849-850. https://doi.org/10.1002/tax.12289

Li, S., Liu, W.-Y. \& Li, D.-H. 2013. Epiphytic lichens in subtropical forest ecosystems in southwest China: Species diversity and implications for conservation. Biol. Conservation 159: 88-95. https:// doi.org/10.1016/j.biocon.2012.12.027

Lücking, R. 2019. Stop the abuse of time! Strict temporal banding is not the future of rank-based classifications in fungi (including lichens) and other organisms. Crit. Rev. Pl. Sci. 38: 199-253. https://doi.org/10.1080/07352689.2019.1650517

Lücking, R., Dal Forno, M., Sikaroodi, M., Gillevet, P.M., Bungartz, F., Moncada, B., Yánez-Ayabaca, A., Chaves, J.L., Coca, L.F. \& Lawrey, J.D. 2014. A single macrolichen constitutes hundreds of unrecognized species. Proc. Natl. Acad. Sci. U.S.A. 111: 11091-11096. https://doi.org/10.1073/pnas.1403517111

Lücking, R., Nelsen, M.P., Aptroot, A., Benatti, M.N., Binh, N.Q., Gueidan, C., Gutiérrez, M.C., Jungbluth, P., Lumbsch, H.T., Marcelli, M.P., Moncada, B., Naksuwankul, K., Orozco, T., Salazar-Allen, N. \& Upreti, D.K. 2016. A pot-pourri of new species of Trypetheliaceae resulting from molecular phylogenetic studies. Lichenologist 48: 639-660. https://doi.org/10.1017/ S0024282916000475

Lücking, R., Hodkinson, B.P. \& Leavitt, S.D. 2017a. The 2016 classification of lichenized fungi in the Ascomycota and Basidiomycota - Approaching one thousand genera. Bryologist 119: 361-416. https://doi.org/10.1639/0007-2745-119.4.361

Lücking, R., Moncada, B., McCune, B., Farkas, E., Goffinet, B., Parker, D., Chaves, J.L., Lőkös, L., Nelson, P.R., Spribille, T., Stenroos, S., Wheeler, T., Yanez-Ayabaca, A., Dillman, K., Gockman, O.T., Goward, T., Hollinger, J., Tripp, E.A., Villella, J., Álvaro-Alba, W.R., Arango, C.J., Cáceres, M.E.S., Coca, L.F., Printzen, C., Rodríguez, C., Scharnagl, K., Rozzi, R., Soto-Medina, E. \& Yakovchenko, L.S. 2017b. Pseudocyphellaria crocata (Ascomycota: Lobariaceae) in the Americas is revealed to be thirteen species, and none of them is P. crocata. Bryologist 120: 441-500. https:// doi.org/10.1639/0007-2745-120.4.14

Lücking, R., Aime, M.C., Robbertse, B., Miller, A.N., Ariyawansa, H.A., Aoki, T., Cardinali, G., Crous, P.W., Druzhinina, I.S., Geiser, D.M. \& Hawksworth, D.L. 2020a. Unambiguous identification of fungi: Where do we stand and how accurate and precise is fungal DNA barcoding? IMA Fungus 11: 1c32. https://doi.org/10.1186/s43008-020-00033-z

Lücking, R., Truong, B.V., Huong, D.T.T., Le, N.H., Nguyen, Q.D., Nguyen, V.D., Von Raab-Straube, E., Bollendorff, S., Govers, K. \& Di Vincenzo, V. 2020b. Caveats of fungal barcoding: A case study in Trametes s.lat. (Basidiomycota: Polyporales) in Vietnam reveals multiple issues with mislabelled reference sequences and calls for third-party annotations. Willdenowia 50: 383-403. https://doi.org/10.3372/wi.50.50302

Lumbsch, T.H. \& Leavitt, S.D. 2011. Goodbye morphology? A paradigm shift in the delimitation of species in lichenized fungi. Fungal Diversity 50: 59-72. https://doi.org/10.1007/s13225-011$0123-\mathrm{z}$

Magain, N. \& Sérusiaux, E. 2015. Dismantling the treasured flagship lichen Sticta fuliginosa (Peltigerales) into four species in Western Europe. Mycol. Progr. 14: art. 97. https://doi.org/10.1007/s11557015-1109-0

Magain, N., Goffinet, B. \& Sérusiaux, E. 2012. Further photomorphs in the lichen family Lobariaceae from Reunion (Mascarene archipelago) with notes on the phylogeny of Dendriscocaulon 
cyanomorphs. Bryologist 115: 243-254. https://doi.org/10.1639/ 0007-2745-115.2.243

Magain, N., Miadlikowska, J., Goffinet, B., Sérusiaux, E. \& Lutzoni, F. 2017. Macroevolution of specificity in cyanolichens of the genus Peltigera section Polydactylon (Lecanoromycetes, Ascomycota). Syst. Biol. 66: 74-99. https://doi.org/10.1007/ s11557-015-1109-0

Magain, N., Truong, C., Goward, T., Niu, D., Goffinet, B., Sérusiaux, E., Vitikainen, O., Lutzoni, F. \& Miadlikowska, J. 2018. Species delimitation at a global scale reveals high species richness with complex biogeography and patterns of symbiont association in Peltigera section Peltigera (lichenized Ascomycota: Lecanoromycetes). Taxon 67: 836-870. https://doi.org/10.12705/ 675.3

Makryi, T.V. 2008. Lichens of the genus Sticta (Lobariaceae) in Russia. Bot. Zhurn. (St. Petersburg) 93: 304-316.

Massalongo, A. 1853. Memorie lichenografiche con un' appendice alle ricerche sull' autonomia dei licheni crostosi. Verona: A spese di H. F. Münster. https://books.google.it/books?id=VzIVAAAAYAAJ

Miadlikowska, J., Magain, N., Pardo de la Hoz, C., Niu, D., Goward, T., Sérusiaux, E. \& Lutzoni, F. 2018. Species in section Peltidea (aphthosa group) of the genus Peltigera remain cryptic after molecular phylogenetic revision. Pl. Fungal Syst. 63: 45-64. https://doi.org/10.2478/pfs-2018-0007

Miller, M.A., Pfeiffer, W. \& Schwartz, T. 2010. Creating the CIPRES Science Gateway for inference of large phylogenetic trees. Pp. 45-52 in: Proceedings of the Gateway Computing Environments Workshop (GCE), New Orleans, Louisiana, 14 Nov 2010. Piscataway: IEEE. https://doi.org/10.1109/GCE.2010.5676129

Moncada, B., Coca, L.F. \& Lücking, R. 2013a. Neotropical members of Sticta (lichenized Ascomycota: Lobariaceae) forming photosymbiodemes, with the description of seven new species. Bryologist 116: 169-200. https://doi.org/10.1639/0007-2745-116.2.169

Moncada, B., Lücking, R. \& Betancourt-Macuase, L. 2013b. Phylogeny of the Lobariaceae (lichenized Ascomycota: Peltigerales), with a reappraisal of the genus Lobariella. Lichenologist 45: 203-263. https://doi.org/10.1017/S0024282912000825

Moncada, B., Lücking, R. \& Suárez, A. 2014. Molecular phylogeny of the genus Sticta (lichenized Ascomycota: Lobariaceae) in Colombia. Fungal Diversity 64: 205-231. https://doi.org/10. 1007/s13225-013-0230-0

Moritz, C. 1994. Defining "Evolutionarily Significant Units" for conservation. Trends Ecol. Evol. 9: 373-375. https://doi.org/10. 1016/0169-5347(94)90057-4

Nguyen, D.T.M., Do, L.T.M., Tuyet, H.T.N., Ho, M.K.Q., Nguyen, H.T., Mortier, J. \& Nguyen, P.K.P. 2019. Chemical constituents of the lichen Dendriscosticta platyphylloides, Lobariaceae. Sci. Technol. Developm. J. 22: 165-172. https://doi.org/10.32508/stdj. v22i1.1219

Nylander, W. 1860 (“1858-1860”). Synopsis methodica lichenum omnium hucusque cognitorum praemissa introductione lingua gallica tractata, vol. 1. Parisiis [Paris]: ex typis L. Martinet. https:// books.google.at/books?id=0dA9AAAAYAAJ

Nylander, W. 1885. Addenda nova ad lichenographiam Europaeam. Flora 68: 295-301.

Nylander, W. 1890. Lichenes Japoniae: Accedunt observationibus lichenes insulae Labuan. Parisiis [Paris]: e typis Paul. Schmidt. https://gallica.bnf.fr/ark:/12148/bpt6k96798r

Ohmura, Y. \& Kashiwadani, H. (eds.) 2018. Checklist of lichens and allied fungi of Japan. National Museum of Nature and Science Monographs, No. 49. Tokyo: National Museum of Nature and Science.

Orange, A., James, P.W. \& White, F.J. 2001. Microchemical methods for the identification of lichens. London: British Lichen Society.

Orock, E.A., Ayuk, E., Leavitt, S.D., Fonge, B.A., St. Clair, L.L. \& Lumbsch, H.T. 2012. DNA-based identification of lichen-forming fungi: Can publicly available sequence databases aid in lichen diversity inventories of Mount Cameroon (West Africa)?
Lichenologist 44: 833-839. https://doi.org/10.1017/S00242829 12000424

Penn, O., Privman, E., Landan, G., Graur, D. \& Pupko, T. 2010. An alignment confidence score capturing robustness to guide-tree uncertainty. Molec. Biol. Evol. 27: 1759-1767. https://doi.org/ 10.1093/nar/gkq443

Pimm, S.L., Jenkins, C.N., Abell, R., Brooks, T.M., Gittleman, J.L., Joppa, L.N., Raven, P.H., Roberts, C.M. \& Sexton, J.O. 2014. The biodiversity of species and their rates of extinction, distribution, and protection. Science 344: 1246752. https://doi.org/10. 1126/science. 1246752

Pons, J., Barraclough, T.G., Gomez-Zurita, J., Cardoso, A., Duran, D.P., Hazell, S., Kamoun, S., Sumlin, W.D. \& Vogler, A.P. 2006. Sequence-based species delimitation for the DNA taxonomy of undescribed insects. Syst. Biol. 55: 595-609. https://doi.org/10.1080/10635150600852011

Puillandre, N., Lambert, A., Brouillet, S. \& Achaz, G. 2012. ABGD, Automatic Barcode Gap Discovery for primary species delimitation. Molec. Ecol. 21: 1864-1877. https://doi.org/10.1111/j. 1365-294X.2011.05239.X

Rambaut, A. \& Drummond, A.J. 2013. Tracer, version 1.6. http:// tree.bio.ed.ac.uk/software/tracer/

Rambaut, A., Drummond, A.J., Xie, D., Baele, G. \& Suchard, M.A. 2018. Posterior summarisation in Bayesian phylogenetics using Tracer 1.7. Syst. Biol. 67: 901-904. https://doi.org/10.1093/sys bio/syy032

Ranft, H., Moncada, B., De Lange, P.J., Lumbsch, H.T. \& Lücking, R. 2018. The Sticta filix morphodeme (Ascomycota: Lobariaceae) in New Zealand with the newly recognized species $S$. dendroides and $S$. menziesii: Indicators of forest health in a threatened island biota? Lichenologist 50: 185-210. https://doi. org/10.1017/S0024282917000706

Rannala, B. \& Yang, Z. 2003. Bayes estimation of species divergence times and ancestral population sizes using DNA sequences from multiple loci. Genetics 164: 1645-1656. https://doi.org/10.1093/ genetics/164.4.1645

Rivas Plata, E., Parnmen, S., Staiger, B., Mangold, A., Frisch, A., Weerakoon, G., Hernández, J., Cáceres, M., Kalb, K., Sipman, H., Common, R., Nelsen, M., Lücking, R. \& Lumbsch, T. 2013. A molecular phylogeny of Graphidaceae (Ascomycota, Lecanoromycetes, Ostropales) including 428 species. MycoKeys 6: 55-94. https://doi.org/10.3897/mycokeys.6.3482

Schwarz, G. 1978. Estimating the dimension of a model. Ann. Statist. 6: 461-464.

Shrimpton, R. 2019. GIFT, transnational corporations and the sixth mass extinction. World Nutr. 10: 143-146. https://doi.org/10. 26596/wn.2019104143-146

Simon, A., Lücking, R., Moncada, B., Mercado-Díaz, J.A., Bungartz, F., Cáceres, M.E.D.S., Gumboski, E.L., Martins, S.M.D.A., Spielmann, A., Parker, D. \& Goffinet, B. 2020. Emmanuelia, a new genus of lobarioid lichen-forming fungi (Ascomycota: Peltigerales): Phylogeny and synopsis of accepted species. Pl. Fungal Syst. 65: 76-94. https://doi.org/10.35535/pfsyst-20200004

Søchting, U. 1999. Lichens of Bhutan: Biodiversity and use. Copenhagen: Botanical Institute, University of Copenhagen.

Spribille, T., Fryday, A.M., Pérez-Ortega, S., Svensson, M., Tonsberg, T., Ekman, S., Holien, H., Resl, P., Schneider, K., Stabentheiner, E., Thüs, H., Vondrák, J. \& Sharman, L. 2020. Lichens and associated fungi from Glacier Bay National Park, Alaska. Lichenologist 52: 61-181. https://doi.org/10.1017/ S0024282920000079

Stamatakis, A. 2014. RAxML version 8: A tool for phylogenetic analysis and post-analysis of large phylogenies. Bioinformatics 30 : 1312-1313. https://doi.org/10.1093/bioinformatics/btu033

Stehn, S.E., Walton, J.K. \& Roland, C.A. 2013. A bryophyte species list for Denali National Park and Preserve, Alaska, with comments 
on several new and noteworthy records. Evansia 30: 31-45. https://doi.org/10.1639/079.030.0105

Takahashi, K. 2006. Taxonomic revision of the genus Sticta (Lobariaceae, lichenized Ascomycota) in East Asia. Ph.D. thesis. Hiroshima University, Higashihiroshima, Japan.

Takahashi, K., Wang, L., Tsubota, H. \& Deguchi, H. 2006. Photosymbiodemes Sticta wrightii and Dendriscocaulon sp. (lichenized Ascomycota) from Yunnan, China. J. Hattori Bot. Lab. 100: 783-796.

Takahashi, K., Anzai, T., Kinoshita, Y. \& Harada, H. 2012. Sticta praetextata and $S$. sublimbata (lichenized Ascomycota; Lobariaceae) new to Japan. Lichenology 11: 1-7.

Taylor, J.W., Jacobson, D.J., Kroken, S., Kasuga, T., Geiser, D.M., Hibbett, D.S. \& Fisher, M.C. 2000. Phylogenetic species recognition and species concepts in fungi. Fungal Genet. Biol. 31: 21-32. https://doi.org/10.1006/fgbi.2000.1228

Thomson, S.A., Pyle, R.L., Ahyong, S.T., Alonso-Zarazaga, M., Ammirati, J., Araya, J.F., Ascher, J.S. \& al., 2018. Taxonomy based on science is necessary for global conservation. PLoS Biol. 16: e2005075. https://doi.org/10.1371/journal.pbio.2005075

Tønsberg, T. \& Goward, T. 2001. Sticta oroborealis sp. nov., and other pacific North American lichens forming Dendriscocauloid cyanotypes. Bryologist 104: 12-23. https://doi.org/10.1639/ 0007-2745(2001)104[0012:SOSNAO]2.0.CO;2

Trevisan, V. 1869. Lichenotheca Veneta, ser. I, fasc. II (Appendix): 77. Lobaria platyphylla Trevis. http://dryades.units.it/lichenotheca veneta/en/index.php

Tuckerman, E. 1859. Supplement to an Enumeration of North American Lichenes. Amer. J. Sci. Arts 28: 200-206.

Türk, R. \& Wunder, H. 2000. Die Flechten des Nationalparks Berchtesgaden und angrenzender Gebiete. Forschungsbericht, 42. Berchtesgaden: Nationalparkverwaltung Berchtesgaden.

Upreti, D.K.M. \& Ranjan, M. 1988. A note on some macro lichens from Thimphu District, Bhutan. J. Recent Adv. Appl. Sci. 3: 426-432.

Wang, L.S. \& Qian, Z.G. 2013. Zhong guo yao yong di yi tu jian [Illustrated medicinal lichens of China]. Kunming: Yunnan Keji Chubanshe. [Bilingual in English and Chinese]

Weerakoon, G. 2015. Fascinating lichens of Sri Lanka. Colombo: Ceylon Tea Services, PLC.

Weerakoon, G. \& Aptroot, A. 2014. Over 200 new lichen records from Sri Lanka, with three new species to science. Cryptog. Mycol. 35: 51-62. https://doi.org/10.7872/crym.v35.iss1.2014.51

Wei, J.C. 1991. An enumeration of lichens in China. Beijing: International Academic Publishers.
White, T.J., Bruns, T., Lee, S. \& Taylor, J.L. 1990. Amplification and direct sequencing of fungal ribosomal RNA genes for phylogenetics. Pp. 315-322 in: Innis, M.A., Gelfand, D.H., Sninsky, J.J. $\&$ White, T.J. (eds.), PCR protocols: A guide to methods and applications. San Diego: Academic Press.

Widhelm, T.J., Bertoletti, F.R., Asztalos, M.J., Mercado-Díaz, J.A., Huang, J.P., Moncada, B. Lücking, R., Magain, N., Sérusiaux, E., Goffinet, B., Crouch, N., Mason-Gamer, R. \& Lumbsch, H.T. 2018. Oligocene origin and drivers of diversification in the genus Sticta (Lobariaceae, Ascomycota). Molec. Phylogen. Evol. 126: 58-73. https://doi.org/10.1016/j.ympev.2018.04.006

Widhelm, T.J., Grewe, F., Huang, J.P., Mercado-Díaz, J.A., Goffinet, B., Lücking, R., Moncada, B., Mason-Gamer, R. \& Lumbsch, H.T. 2019. Multiple historical processes obscure phylogenetic relationships in a taxonomically difficult group (Lobariaceae, Ascomycota). Sci. Rep. 9: art. 8968. https://doi.org/10.1038/ s41598-019-45455-x

Wolseley, P.A., Begona, A.H. \& McCarthy, P.M. 2002. Catalogue of the lichens of Thailand. Bull. Nat. Hist. Mus. London, Bot. 32: 13-59. https://doi.org/10.1017/S0968044602000038

Xu, Z.F. \& Liu, H.M. 1996. The loss and restoration of biodiversity in degraded tropical rainforest ecosystems. Acta Bot. Yunnan. 18: 433-438.

Yang, Z. \& Rannala, B. 2010. Bayesian species delimitation using multilocus sequence data. Proc. Natl. Acad. Sci. U.S.A. 107: 9264-9269. https://doi.org/10.1073/pnas.0913022107

Yoshimura, I. 1974. Lichen flora of Japan in colour. Osaka: Hoikusha.

Yoshimura, I. \& Hurutani, R. 1987. Fine structures of cyphellae, pseudocyphellae and allied structures in lichen family Lobariaceae as determined by scanning electron microscopy. Bull. Kochi Gakuen Coll. 18: 345-359. [in Japanese with English abstract]

Yu, G., Smith, D.K., Zhu, H., Guan, Y. \& Lam, T.T.T. 2017. Ggtree: An $\mathrm{R}$ package for visualization and annotation of phylogenetic trees with their covariates and other associated data. Meth. Ecol. Evol. 8: 28-36. https://doi.org/10.1111/2041210X.12628

Yule, G. 1924. A mathematical theory of evolution, based on the conclusions of Dr. JC Willis. Philos. Trans., Ser. B. 213: 21-87. https://doi.org/10.1098/rstb.1925.0002

Zahlbruckner, A. 1925. Catalogus lichenum universalis, vol. 3. Leipzig: Borntraeger.

Appendix 1. Voucher information and GenBank accession numbers for specimens used in the phylogenetic analyses.

Species name, authority, country, region, collector, collector number, herbarium code, and GenBank accession numbers for the nuclear ribosomal internal transcribed spacer region (ITS), the RNA polymerase II largest subunit (RPBI), the translation elongation factor-1 alpha gene (EF1- $\alpha$ ), and the DNA replication licensing factor (MCM7). Newly generated sequences are highlighted in bold. Missing sequences are indicated by a dash (-). The bold numbers in parentheses indicate the different lineages with the morpho-chemotype of $D$. hookeri. For species producing photomorphs, chloromorphs and cyanomorphs are indicated using the suffix method proposed by Heiðmarsson \& al. (1997); when unspecified, the fungus is primarily associated to a green alga. For accessions retrieved from GenBank, names denote the original sequence labels.

Dendriscosticta gelida Ant.Simon, Goward \& T.Sprib./chlor.: Russia, Komi Republic, A. Simon \& N. Semenova 177 (LG), MT590974, -, -, -; Russia, Komi Republic, A. Simon \& N. Semenova 178 (LG), MT590975, MT612486, MT612645, MT612566; Russia, Komi Republic, A. Simon \& N. Semenova 179 (LG), MT590976, -, -, -; Russia, Komi Republic, A. Simon \& N. Semenova 180 (LG), MT590977, -, -, -; Russia, Krasnoyarsk Krai, A. Simon (leg. N.V. Stepanov) 213 (LG), MT590983, MT612489, MT612646, MT612570; Russia, Krasnoyarsk Krai, A. Simon (leg. N.V. Stepanov) 216 (LG), MT590986, MT612480, MT612639, MT612560; Russia, Krasnoyarsk Krai, A. Simon (leg. N.V. Stepanov) 219 (LG), MT590987, MT612481, MT612640, MT612561; Russia, Krasnoyarsk Krai, A. Simon (leg. N.V. Stepanov) 220 (LG), MT590988, MT612485, MT612644, MT612565; Canada, British Columbia, A. Simon \& T. Spribille 474 (LG), MT590969, MT612483, MT612642, MT612563; Canada, British Columbia, A. Simon \& T. Spribille 478 (LG), MT590971, MT612484, MT612643, MT612564; Canada, British Columbia, K. McKeown 2269 (CONN), MT590848, MT612478, MT612637, MT612558; U.S.A., Alaska, T. Tønsberg 27680 (BG), MT590826, -, -, -; U.S.A., Alaska, T. Tønsberg 29745 (BG), MT590834, -, -, -; U.S.A., Alaska, T. Tønsberg 29745 (BG), MT590835, -, -, -; U.S.A., Alaska, T. Tønsberg 29745 (BG), MT590836, -,-,-; Canada, British Columbia, T. Goward 02-1827 (UBC), MT590841, -,-,-; India, Uttarakhand, R. Bajpai \& D.K. Upreti 12-011 443 (LG), MT590982,-,-, MT612567; China, L.S. Wang 16-52799 (KUN), MT590785, -, -, -; China, L.S. Wang 17-55766 (KUN), MT590797, -, -, -; Russia, Krasnoyarsk Krai, A. Simon (leg. N.V. Stepanov) 214 (LG), MT590984, -,-,--; Russia, Krasnoyarsk Krai, A. Simon (leg. N.V. Stepanov) 215 (LG), MT590985, -, -,-; Canada, British Columbia, T. Goward 99-395 (UBC), MT590838, -, -, -; U.S.A., Alaska, T. Spribille 26302 (KLGO), MT590991, -,-, -; U.S.A., Alaska, T. Spribille 36122 (MSC), MN483092, -, -, -; U.S.A., Alaska, T. Spribille 39269 (MSC), MN483093, -, -, -; 
Appendix 1. Continued.

Canada, British Columbia, T. Spribille 40915 (hb. Spribille), MT590996, -, -, -; Canada, British Columbia, T. Spribille 31992 (CONN), MT590849, MT612490, MT612647, MT612571; Russia, Krasnoyarsk Krai, N.V. Stepanov s.n. DNA AS6194 (LE), MT590978, MT612487, -, MT612568; Russia, Krasnoyarsk Krai, N.V. Stepanov s.n. DNA AS6197 (LE), MT590979, MT612488, -, MT612569; Dendriscosticta gelida Ant.Simon, Goward \& T.Sprib./cyan.: Canada, British Columbia, A. Simon \& T. Spribille 470 (LG), MT590967, MT612482, MT612641, MT612562; China, B. Goffinet 10018 (CONN), MT590856, -, -, -; U.S.A., Minnesota, C. Wetmore 22669 (MIN), MT590912, -, -, -; Canada, British Columbia, T. Tønsberg 27584 (UBC), MT590823, -, -; Canada, British Columbia, T. Tønsberg 27666 (UBC), MT590824, -, -, -; Canada, British Columbia, T. Tønsberg 27668 (UBC), MT590825, -, U.S.A., Alaska, T. Tønsberg 29745 (BG), MT590837, -, -, -; Canada, British Columbia, T. Tønsberg 29756 (UBC), MT590828, -, -, -; Canada, British Columbia, T. Tønsberg 29759 (UBC), MT590844, -, -, -; Canada, British Columbia, T. Tønsberg 29767 (UBC), MT590829, -, -, -; Canada, British Columbia, T. Tønsberg 29859 (UBC), MT590830, -, -, -; Canada, British Columbia, T. Tønsberg 30205 (UBC), MT590831, -, -, -; Canada, British Columbia, T. Tønsberg 30333 (UBC), MT590832, -, -, -; Canada, British Columbia, T. Tønsberg 30334 (UBC), MT590833, -, -, -; China, B. Goffinet 10715cy (CONN), MT590864, MT612479, MT612638, MT612559; China, L.S. Wang 13-38201 (KUN), MT590870, -, -, -; China, L.S. Wang 13-38288 (KUN), MT590876, MT612491, MT612648, MT612572; China, L.S. Wang 16-51148 (KUN), MT590959, -, -, -; China, L.S. Wang 16-51179 (KUN), MT590960, China, L.S. Wang 16-52853 (KUN), MT590964, U.S.A., Alaska, T. Spribille DNA CONN T1285b (MSC), MT590994,

Dendriscosticta aff. hookeri (Trevis) Moncada \& Lücking: Japan, Hokkaido, A. Simon, N. Magain \& E. Sérusiaux 603 (LG), MT590932,-,-,-; Japan, Honshu, A. Simon \& E. Sérusiaux 659 (LG), MT590945, MT612539, MT612696, MT612618; China, B. Goffinet 9997 (CONN), MT590851,--,-,-; China, L.S. Wang 14-46019 (KUN), MT590900, MT612540, MT612697, MT612619; Dendriscosticta aff. hookeri (Trevis) Moncada \& Lücking (1): Taiwan, B. Goffinet \& E. Sérusiaux 13010 (CONN), MT590915, MT612530, MT612687, MT612610; Taiwan, B. Goffinet \& E. Sérusiaux 13016 (CONN), MT590916, -,-,-,; Taiwan, B. Goffinet \& E. Sérusiaux 13026 (CONN), MT590917, MT612531, MT612688, MT612611; Taiwan, B. Goffinet \& E. Sérusiaux 13027 (CONN), MT590918, MT612532, MT612689, MT612612; Taiwan, B. Goffinet \& E. Sérusiaux 13523 (CONN), MT590926, -, -, -; Taiwan, B. Goffinet \& E. Sérusiaux 13525 (CONN), MT590927, MT612533, MT612690, MT612613; Taiwan, E. Sérusiaux \& B. Goffinet 221T (LG), MT590813, MT612535, MT612692, MT612615; Taiwan, E. Sérusiaux \& B. Goffinet 23T (LG), MT590803, MT612534, MT612691, MT612614; Taiwan, E. Sérusiaux \& B. Goffinet $28 T$ (LG), MT590804, -, -, -; Taiwan, E. Sérusiaux \& B. Goffinet $294 T$ (LG), MT590818, -, -, -; Taiwan, E. Sérusiaux \& B. Goffinet $3 T$ (LG), MT590778, MT612537, MT612694, MT612617; Taiwan, E. Sérusiaux \& B. Goffinet 406T (LG), MT590820, -,-,-; Taiwan, E. Sérusiaux \& B. Goffinet 413T (LG), MT590821, MT612536, MT612693, MT612616; Taiwan, E. Sérusiaux \& B. Goffinet 57T (LG), MT590805, -, -; Dendriscosticta aff. hookeri (Trevis) Moncada \& Lücking (2): China, B. Goffinet 9975 (CONN), MT590853, MT612515, MT612672, MT612597; China, B. Goffinet 9975b (CONN), MT590861, -, -, -; China, B. Goffinet 10012 (CONN), MT590908, -, -, -; China, B. Goffinet 10738 (CONN), MT590866, -, -, -; China, L.S. Wang 13-38251 (KUN), MT590877, -, -, -; China, L.S. Wang 13-38285 (KUN), MT590872, -, -, -; China, L.S. Wang 13-38290 (KUN), MT590871, -, -, -; China, L.S. Wang 14-46205 (KUN), MT590890, -, -, -; China, L.S. Wang 14-46768 (KUN), MT590904, China, L.S. Wang 14-46781 (KUN), MT590906, -, -, -; China, L.S. Wang 14-46813 (KUN), MT590883, MT612516, MT612673, MT612598; China, L.S. Wang 16-52068 (KUN), MT590782, -, -, -; China, L.S. Wang 16-52079 (KUN), MT590784, -, -, -; China, L.S. Wang 16-54386 (KUN), MT590789, -, -, -; China, L.S. Wang 16-54408 (KUN), MT590790, -, -, -; China, L.S. Wang 17-55458 (KUN), MT590793, -, -, -; China, L.S. Wang 17-55477 (KUN), MT590794, -, -, -; China, L.S. Wang 17-55691 (KUN), MT590796, -,-,-; China, L.S. Wang 17-56600 (KUN), MT590801, -, -, -; Dendriscosticta aff. hookeri (Trevis) Moncada \& Lücking (3): Japan, Hokkaido, A. Simon, N. Magain \& E. Sérusiaux 590 (LG), MT590928, -, -, -; Japan, Hokkaido, A. Simon, N. Magain \& E. Sérusiaux 594 (LG), MT590930, MT612517, MT612674, MT612599; Japan, Hokkaido, A. Simon, N. Magain \& E. Sérusiaux 600 (LG), MT590931, -, -, -; Japan, Hokkaido, A. Simon, N. Magain \& E. Sérusiaux 615 (LG), MT590935, -, -, -; Japan, Hokkaido, A. Simon, N. Magain \& E. Sérusiaux 616 (LG), MT590936, MT612518, MT612675, MT612600; Japan, Hokkaido, A. Simon, N. Magain \& E. Sérusiaux 620 (LG), MT590937, -, -, -; Japan, Hokkaido, A. Simon, N. Magain \& E. Sérusiaux 635 (LG), MT590941, MT612519, MT612676, MT612601; Japan, Honshu, A. Simon \& E. Sérusiaux 666 (LG), MT590944, MT612520, MT612677, -; Taiwan, E. Sérusiaux \& B. Goffinet 171T (LG), MT590810, MT612521, MT612678, MT612602; Taiwan, E. Sérusiaux \& B. Goffinet $207 T$ (LG), MT590811, MT612522, MT612679, MT612603; Taiwan, E. Sérusiaux \& B. Goffinet 254T (LG), MT590817, -, -, -; Japan, Hokkaido, A. Simon (leg. N. Magain) 687 (LG), MT590951, -, -, -; Japan, Hokkaido, A. Simon (leg. N. Magain) 688 (LG), MT590952, -, -, -; Japan, Hokkaido, A. Simon (leg. N. Magain) 691 (LG), MT590954, -, -, -; Japan, Hokkaido, A. Simon (leg. N. Magain) 692 (LG), MT590955, -, -,-; Japan, Hokkaido, A. Simon (leg. N. Magain) 694 (LG), MT590957, -, -, -; Dendriscosticta aff. hookeri (Trevis) Moncada \& Lücking (4): Taiwan, B. Goffinet \& E. Sérusiaux 13005 (CONN), MT110111, MT612523, MT612680, MT612604; Taiwan, B. Goffinet \& E. Sérusiaux 13317 (CONN), MT590922, MT612524, MT612681, MT612605; Taiwan, E. Sérusiaux \& B. Goffinet 249T(LG), MT590815,-,-,--; Taiwan, E. Sérusiaux \& B. Goffinet 378T (LG), MT590819, -, -, -; Dendriscosticta aff. hookeri (Trevis) Moncada \& Lücking (5): Japan, Honshu, A. Simon \& E. Sérusiaux 678 (LG), MT590949, MT612547, MT612705, MT612626; China, B. Goffinet 9998 (CONN), MT590862, -, -, -; China, B. Goffinet 10017 (CONN), MT590859, MT612541, MT612698, MT612620; China, B. Goffinet 10035 (CONN), MT590860, -, -,-; China, B. Goffinet 10081 (CONN), MT590855,-, -, -; China, B. Goffinet 10711 (CONN), MT590910, MT612548, MT612706, MT612627; China, B. Goffinet 10735 (CONN), MT590865, -, -, -; China, L.S. Wang 13-38197 (KUN), MT590868, -, -, -; China, L.S. Wang 13-38254 (KUN), MT590869, -, -, -; China, L.S. Wang 14-46775 (KUN), MT590878, -, MT612699, MT612621; China, L.S. Wang 16-52036 (KUN), MT590780, -, -, -; China, L.S. Wang 16-54410 (KUN), MT590791, -, -, -; China, L.S. Wang 17-56439 (KUN), MT590799, -,-,-; China, L.S. Wang 17-56480 (KUN), MT590800,-,-,-; China, L.S. Wang 17-56770 (KUN), MT590802, -,-,-; Dendriscosticta insinuans (Nyl.) Ant.Simon, Magain \& Sérus.: Japan, Hokkaido, A. Simon, N. Magain \& E. Sérusiaux 591 (LG), MT590929, MT612528, MT612685, -, Japan, Hokkaido, A. Simon, N. Magain \& E. Sérusiaux 611 (LG), MT590933, -, -, -; Japan, Hokkaido, A. Simon, N. Magain \& E. Sérusiaux 625 (LG), MT590939, -, -, -; Japan, Hokkaido, A. Simon, N. Magain \& E. Sérusiaux 626 (LG), MT590940, -, -, -; Japan, Honshu, A. Simon \& E. Sérusiaux 653 (LG), MT590943, MT612538, MT612695, -; Japan, Honshu, A. Simon \& E. Sérusiaux 668 (TNS), MT590946, MT612529, MT612686, MT612609; Japan, Hokkaido, A. Simon (leg. N. Magain) 685 (LG), MT590950,-,-,--; Japan, Hokkaido, A. Simon (leg. N. Magain) 693 (LG), MT590956,-,-,-; Sticta nylanderiana Zahlbr.: China, K. Takahashi (KUN), AB245119, -, -, -; South Korea, J.S. Hur (KoLRI [000468]), KF730792, -, -, -; Japan, Hokkaido, K. Takahashi 2975 (HIRO), AB245120, -, -, -; South Korea, J.S. Hur (KoLRI [000321]), KF730790, -, -, -; Taiwan, H. Harada 21782 (CBM-FL), AB245121, -, -, -; South Korea, J.S. Hur (KoLRI [000460]), KF840681, -, -, -; Dendriscosticta oroborealis (Goward \& Tønsberg) Moncada \& Lücking/ chlor.: Canada, British Columbia, A. Simon \& T. Spribille 472 (LG), MT590968, MT612475, MT612634, MT612555; Canada, British Columbia, A. Simon \& T. Spribille 475 (LG), MT590970, MT612476, MT612635, MT612556; China, B. Goffinet 10010 (CONN), MT590858, -, -, -; China, B. Goffinet 10011 (CONN), MT590854, MT612477, MT612636, MT612557; Canada, British Columbia, T. Goward 02-1091 (UBC), MT590839,--,-,-; Canada, British Columbia, T. Goward 02-1725 (UBC), MT590842,-,-,-; China, B. Goffinet 10715ch (CONN), MT590863, MT612473, MT612632, MT612553; Canada, British Columbia, T. Goward 92-1973 (UBC), MT590840,-,-,-; Canada, British Columbia, T. Goward 95-459 (UBC), MT590827,-,-,--; Canada, British Columbia, T. Spribille 29815 (hb. Spribille), MT590990, -,-,-; Canada, British Columbia, T. Tønsberg 20664, AF208015, -,-,-; Canada, British Columbia, T. Tønsberg 20665 (UBC), MT590843, MT612471, MT612630, MT612551; Canada, British Columbia, A. Arsenault 2003 (UBC), MT590846, -,-,--; Dendriscosticta oroborealis (Goward \& Tønsberg) Moncada \& Lücking/cyan.: Canada, British Columbia, C.R. Bjork 19682 (UBC), MT590850, MT612474, MT612633, MT612554; Canada, British Columbia, T. Tønsberg 20591 (UBC), MT590822, -, -, -; Canada, British Columbia, T. Goward 04-03 1/3 (UBC), MT590847, MT612472, MT612631, MT612552; Canada, British Columbia, T. Spribille 40906 (hb. Spribille), MT590995, -, -, -; China, L.S. Wang 16-51141 (KUN), MT590958, -, -, -; China, L.S. Wang 16-52633 (KUN), MT590962, -, -, -; China, L.S. Wang 16-52837 (KUN), MT590963, China, L.S. Wang 16-53111 (KUN), MT590965,-,-,-; Dendriscosticta phyllidiata Ant.Simon, Goffinet \& Sérus.: Taiwan, B. Goffinet \& E. Sérusiaux 13475 (CONN), MT590923, MT612525, MT612682, MT612606; Taiwan, B. Goffinet \& E. Sérusiaux 13506 (CONN), MT590924, -, -, -; Taiwan, 
Appendix 1. Continued.

B. Goffinet \& E. Sérusiaux 13508 (CONN), MT590925, MT612526, MT612683, MT612607; Taiwan, E. Sérusiaux \& B. Goffinet 218T (LG), MT590812,-,-, -; Taiwan, E. Sérusiaux \& B. Goffinet 228T(LG), MT590814, MT612527, MT612684, MT612608; Dendriscosticta platyphylloides (Nyl.) Moncada \& Lücking/ chlor:: China, B. Goffinet 9962 (CONN), MT590852,-,-,-; China, B. Goffinet 9971 (CONN), MT590857, -, -, -; China, B. Goffinet 10751 (CONN), MT590907,-,-, -; China, B. Goffinet 10753 (CONN), MT590909,-,-, -; China, J. Li 1338999 (KUN), MT590875, -, -, -; China, J. Li 1339019 (KUN), MT590874, MT612494, MT612650, MT612576; China, L.S. Wang 14-46249 (KUN), MT590898, MT612497, MT612653, MT612579; China, L.S. Wang 14-46264 (KUN), MT590899, MT612498, MT612654, MT612580; China, L.S. Wang 14-46283 (KUN), MT590896, -, -, -; China, L.S. Wang 14-46287 (KUN), MT590895, MT612496, MT612652, MT612578; China, L.S. Wang 14-46434 (KUN), MT590881, MT612501, MT612657, MT612583; China, L.S. Wang 14-46510 (KUN), MT590879, MT612495, MT612651, MT612577; China, L.S. Wang 14-46722 (KUN), MT590901, -, -, -; China, L.S. Wang 14-46725 (KUN), MT590902, MT612499, MT612655, MT612581; China, L.S. Wang 14-46730 (KUN), MT590880, -, -, -; China, L.S. Wang 14-46791 (KUN), MT590893, MT612500, MT612656, MT612582; China, L.S. Wang 16-53660 (KUN), MT590787, -, -, -; China, L.S. Wang 16-53684 (KUN), MT590788, -, -, -; China, L.S. Wang 16-54413 (KUN), MT590792,-,-, -; China, L.S. Wang 17-55485 (KUN), MT590795, -, -, -; Dendriscosticta platyphylloides (Nyl.) Moncada \& Lücking/cyan.: China, L.S. Wang 16-51612 (KUN), MT590961, -, -, -; China, L.S. Wang 16-53203 (KUN), MT590966,--,

-; Dendriscosticta praetextata (Räsänen) Moncada \& Lücking: India, Uttarakhand, R. Bajpai \& D.K. Upreti 12-011438 (LG), MT590989, MT612546, MT612704, -; China, L.S. Wang 13-38297 (KUN), MT590873, -, -, -; China, L.S. Wang 14-46081 (KUN), MT590892, MT612543, MT612701, MT612623; China, L.S. Wang 14-46154 (KUN), MT590884, -, -, -; China, L.S. Wang 14-46159 (KUN), MT590903, MT612545, MT612703, MT612625; China, L.S. Wang 14-46218 (KUN), MT590886, MT612542, MT612700, MT612622; China, L.S. Wang 14-46246 (KUN), MT110112, -, -, -; China, L.S. Wang 14-46281 (KUN), MT590891, -, -, -; China, L.S. Wang 14-46400 (KUN), MT590887, -, -, -; China, L.S. Wang 14-46496 (KUN), MT590888, -, -, -; China, L.S. Wang 14-46702 (KUN), MT590897, MT612544, MT612702, MT612624; China, L.S. Wang 14-46806 (KUN), MT590889, -, -, -; China, L.S. Wang 14-46812 (KUN), MT590894, -, -, -; China, L.S. Wang 14-46901 (KUN), MT590905, -, -, -; China, L.S. Wang 16-52037 (KUN), MT590781, ,,--- ; China, L.S. Wang 16-52820 (KUN), MT590786,-,-,-; China, L.S. Wang 17-55883 (KUN), MT590798, -, -, -; China, K. Takahashi 2493 (HIRO), AB245122, -, -, -; Dendriscosticta wrightii (Tuck.) Moncada \& Lücking: Japan, Hokkaido, A. Simon, N. Magain \& E. Sérusiaux 638 (FH), MT590942, MT612492, -, MT612573; Japan, Y. Ohmura 8954 (TNS), MT590980, MT612493, MT612649, MT612575; South Korea, J.S. Hur 70739 (KoLRI), MT590972,-,-, MT612574; Taiwan, S. Greenwood D3_31_SPL2 (E), KU862999,-,-,-,; Japan, Honshu, K. Takahashi 2016 (HIRO), AB239342,-,--,-; China, K. Takahashi 2349 (HIRO), AB239339,-, -, -; China, K. Takahashi 2436 (HIRO), AB239344, -, -, -; Japan, Honshu, K. Takahashi 1815 (HIRO), AB239341, -, -, -; Dendriscosticta yatabeana (Müll.Arg.) Ant.Simon, Goffinet \& Sérus./chlor.: Japan, Hokkaido, A. Simon, N. Magain \& E. Sérusiaux 613 (LG), MT590934, MT612504, MT612660, MT612586; Japan, Honshu, A. Simon \& E. Sérusiaux 670 (G), MT590947, MT612507, MT612664, MT612589; Japan, Honshu, A. Simon \& E. Sérusiaux 673 (LG), MT590948, MT612506, MT612662, MT612588; Japan, Hokkaido, A. Simon, N. Magain \& E. Sérusiaux 689 (LG), MT590953, MT612505, MT612661, MT612587; Japan, Y. Ohmura 8962 (TNS), MT590981, MT612511, MT612668, MT612593; China, B. Goffinet 10772 (CONN), MT590911, MT612512, MT612669, MT612594; Taiwan, B. Goffinet \& E. Sérusiaux 13074 (CONN), MT110113, MT612508, MT612665, MT612590; Taiwan, B. Goffinet \& E. Sérusiaux 13214 (CONN), MT590920, MT612509, MT612666, MT612591; Taiwan, B. Goffinet \& E. Sérusiaux 13227 (CONN), MT590921, -, -, -; South Korea, S.O. Oh, J.S. Park \& J.J. Woo 141578 (KoLRI), MT590973, MT612663, -; Taiwan, E. Sérusiaux \& B. Goffinet $119 T$ (LG), MT590808,-, -, -; Taiwan, E. Sérusiaux \& B. Goffinet 130T (LG), MT590809, MT612510, MT612667, MT612592; China, L.S. Wang 14-46445 (KUN), MT590882, MT612503, MT612659, MT612585; China, L.S. Wang 16-52004 (KUN), MT590779, -, -, -; China, L.S. Wang 16-52075 (KUN), MT590783, -, -, -; Taiwan, E. Sérusiaux \& B. Goffinet 250T (LG), MT590816, -, -, -; Taiwan, E. Sérusiaux \& B. Goffinet 64T (LG), MT590806, MT612513, MT612670, MT612595; Taiwan, E. Sérusiaux \& B. Goffinet 64Tbis (LG), MT590807, South Korea, J.S. Hur (KoLRI [008817]), KF730793, -, -, -; Dendriscosticta yatabeana (Müll.Arg.) Ant.Simon, Goffinet \& Sérus./cyan.: China, L.S. Wang 1334 (KUN), MT590867, MT612502, MT612658, MT612584; Dendriscosticta aff. yatabeana (Müll.Arg.) Ant.Simon, Goffinet \& Sérus./chlor.: Japan, Hokkaido, A. Simon, N. Magain \& E. Sérusiaux 624 (LG), MT590938, MT612514, MT612671, MT612596; Dendriscocaulon sp. Nyl.: China, K. Takahashi 2401 (HIRO), AB239338,-,-,-; China, K. Takahashi 2349 (HIRO), AB239340,-,-,-; China, K. Takahashi 2350 (HIRO), AB239337,-,-,-,; Ricasolia quercizans (Michx.) Stizenb., U.S.A., Arkansas, J. Lendemer 45880 (NY), MT590913, MT612550, MT612708, MT612629; R. virens (With.) H.H.Blom \& Tønsberg, Norway, T. Tønsberg 31538 (BG), MT590845, MT612549, MT612707, MT612628.

Appendix 2. Additional specimens of Dendriscosticta examined.

Taxon, country and/or locality, GPS coordinates, substrate and/or habitat, collector(s), date, collection number and/or DNA number, herbarium.

Dendriscosticta gelida Ant.Simon, Goward \& T.Sprib.

Additional specimens examined: CANADA, British Columbia, Kispiox Valley, N of Hazelton, north central BC, Muldoe Forest Service Road at km 13.3, N55 $32^{\prime} 52.78^{\prime \prime} \mathrm{W} 127^{\circ} 43^{\prime} 45.22^{\prime \prime}$, on Tsuga heterophylla, mostly on suppressed trees in a 250-300-year-old forest, K. McKeown, A. Banner \& E. Hall, Jul 2009, McKeown KM09001-4 (CONN), DNA-UConn 2269; British Columbia, Kitimat-Stikine, in the vicinity of Mt Thomlinson, approximately 20 km N of Kispiox,

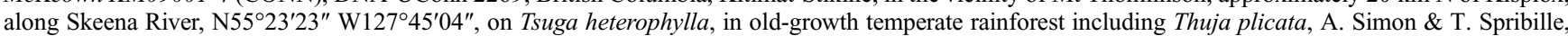
27 Oct 2016, Simon 456 (LG); Simon 470 (LG); Kitimat-Stikine, in the vicinity of Kispiox Mountain, approximately 5 km NW of Kispiox, along Muldoe Service

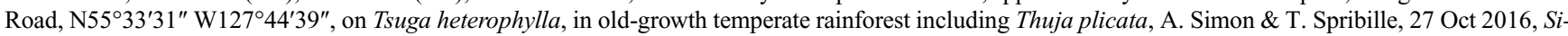

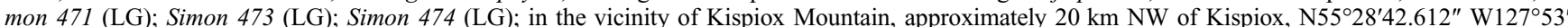
22.242", epiphytic, in old-growth forest including Thuja plicata and Tsuga heterophylla, A. Simon, P. Bartemucci \& Irina Stepanchikova, 22 Sep 2018, Simon

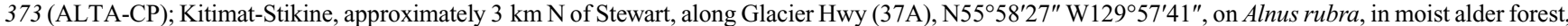
A. Simon \& T. Spribille, 29 Oct 2016, Simon 477 (LG); Simon 478 (LG); Kitimat-Stikine, about 6 km W of Bear Glacier Provincial Park, along Glacier Hwy, Argyle Creek Culvert, N56 $06^{\prime} 59^{\prime \prime}$ W129 48'26", on Alnus rubra, under Populus ("drip zone effect"), at the edge of an old-growth forest, A. Simon \& T. Spribille, 29 Oct 2016, Simon 479 (LG); British Columbia, Fraser-Fort George, northernmost part of the Robson Valley, along Bowron Forest Service Road,

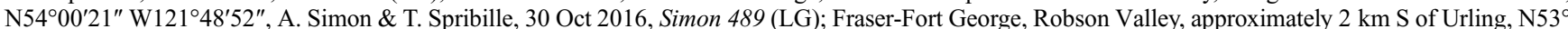
39'04.644" W120'51'59.394", on Alnus, on a damp valley floor, A. Simon, S. Goyette \& G. Tagirdzhanova, 28 Oct 2018, Simon 355 (ALTA-CP); British Co-

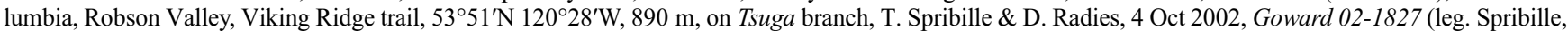
UBC); British Columbia, Quesnel Lake, $52^{\circ} 40^{\prime} \mathrm{N} 120^{\circ} 52^{\prime} \mathrm{W}, 750 \mathrm{~m}$, on Tsuga branch in spray zone of Roaring Creek Falls, T. Goward \& A. Roberts, 2 Aug 1999, Goward 99-345 (UBC); British Columbia, Selkirk Mountains, Incomappleux River, 2.08 km NE of Beaton, steep NW-facing slope above mouth of river on Arrow Lake, N50.74840 W117.70893 ${ }^{\circ}, 13$ Sep 2014, Spribille 40915 (hb. Spribille), DNA extract T1377; Incomappleux River, about $780 \mathrm{~m}$ S of confluence with Battle Brook, N5059.540' W117²35.002', 16 Oct 2009, Spribille 31992 (CONN), DNA extract UConn 2271. CHINA, Sichuan Province, Daofu Co., Yala Snow Mt., nature reserve, N30 $31^{\prime} 13.30^{\prime \prime}$ E101 ${ }^{\circ} 37^{\prime} 25.15^{\prime \prime}$, alt. 3280 m, on Rhododendron bark, L.S. Wang, X.Y. Wang, H.X. Shi, M.X. Yang 16-52799 (KUN-L); Sichuan Province, Daofu Co., Yala Snow Mt., nature reserve, N30 $31^{\prime} 13.30^{\prime \prime}$ E101 ${ }^{\circ} 37^{\prime} 25.5^{\prime \prime}, 3280 \mathrm{~m}$, cyanomorph, on Rhododendron bark, L.S. Wang, X.Y. Wang, H.X. Shi, M.X. Yang 16-51590 (KUN-L 55010); Sichuan Province, Daocheng Co., Yading village, N28 $26^{\prime} 785^{\prime \prime}$ E100 $20^{\prime} 836^{\prime \prime}, 3900$ m, cyanomorph, on Picea, 16 Sep 2002, Wang 02-21537 (KUN-L 18928); on Rhododendron, 4300 m, 15 Sep 2002, Wang 02-21502 (KUN-L 18929); Yunnan Province, Lijiang County, S of Lijiang, Jiuhue village, Laojunshan Mountain, at the border with Jianchuan, along trail from parking lot to peak, N26 $38.538-37.936^{\prime}$ E99 ${ }^{\circ}$ 


\section{Appendix 2. Continued.}

43.509-45.992', 3510-3900 m, montane forest dominated by Abies and further up by Rhododendron, B. Goffinet, L.S. Wang, S.L. Guo \& S.Y. Huang, 16 Jul 2010, Goffinet 10018 (CONN), DNA-UConn 2938; Yunnan Province, Shangri-la County, N of Shangri-la, Xiao Xueshan Mountain, along road from Shangri-la to Sichuan, Geza village, $28^{\circ} 17^{\prime} 08.35^{\prime \prime} \mathrm{N} 99^{\circ} 45^{\prime} 58.20^{\prime \prime} \mathrm{E}, 3461 \mathrm{~m}$, along stream bed, with steep densely vegetated slope with Rhododendron, LS. Wang, X.Y. Wang, D. Liu \& S.Y. Huang, 5 Jul 2012, Goffinet 10735 (CONN), DNA extracts: UConn 3062 (cyanomorph) \& 3063 (cyanomorph); Yunnan Province, Weixi County, on the way from Weixi to Zhongdian, $2950 \mathrm{~m}, \mathrm{~N}^{2} 7^{\circ} 19^{\prime} 37.82^{\prime \prime}$ E99 $16^{\prime} 38.56^{\prime \prime}$, on hemlock, L.S. Wang \& X.Y. Wang, 16 Jun 2013 , Wang 13-38288 (KUN-L), DNA-UConn 3869; Yunnan, Zhongdian Co., Geza village, Daxueshan Mt., N28³4' E99 51', 3600-4200 m, cyanomorph, on Salix, 15 Jun 2004, Wang 04-23253 (KUN-L); on Picea, 11 Oct 2001, Wang 01-20803 (KUN-L); Yunnan, Deqin Co., Baimaxueshan Mt., N28 $22^{\prime}$ E98 $59^{\prime}$, 4320 m, Wang 04-23253, cyanomorph, on Sorbus, 11 Nov 2003, 4000 m, 22 Jun 2013, L.S. Wang \& X.Y. Wang 13-38550 (KUN-L); Yunnan, Simao Co., Caiyanghe, N22 $35^{\prime}$ E101 ${ }^{\circ} 04^{\prime}, 1570$ m, cyanomorph, on bark, 7 Feb 2009, Wang 09-30144 (KUN-L); Yunnan, Nanjian Co., Fenghuangshan Mt., N24 $54^{\prime}$ 19.20" E100 18'44.48", 2240 m, cyanomorph, on Ternstroemia bark, 14 Jun 2012, L.S. Wang \& al. 12-34338 (KUN-L); Yunnan, Jingdong Co., Wuliangshan

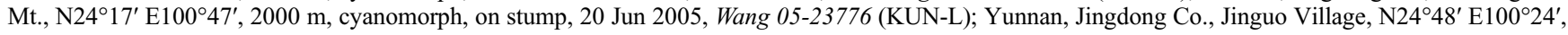

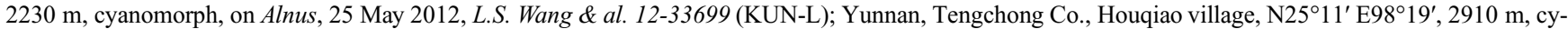
anomorph, on branch, 28 May 2012, L.S. Wang \& al. 12-33368 (KUN-L). INDIA, Uttarakhand, Uttarkashi District, Harkidun forest guest house, N31 ${ }^{\circ} 08^{\prime} 22.17^{\prime \prime}$ E78 $24^{\prime} 30.56^{\prime \prime}, 3205$ m, D.K. Upreti \& R. Bajpai, 11 Jun 2012, Upreti 12-011443 (LG), DNA-Lg AS6213. RUSSIA, Krasnoyarsk Krai, Ermakovsky District,

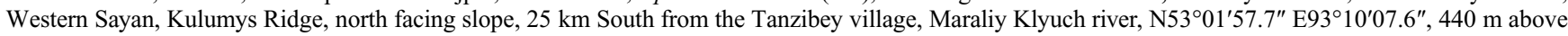
sea level, mixed dark coniferous forest with Betula platyphylla and Sorbus sibirica, on bark of Salix rorida, 15 Jul 2005, leg. N.V. Stepanov s.n. (LE), DNA-Lg AS6194; Krasnoyarsk region, Kuraginskyi District, Eastern Sayan, near Mozharskye Ozera wildlife sanctuary (Tiberkul lake), N5350'21.6" E93 $59^{\prime} 55.1^{\prime \prime}$, $450 \mathrm{~m}$ above sea level, taiga (Abies sibirica + Pinus sibirica), on bark of Sorbus sibirica, N.V. Stepanov, 28 Jul 2011, Simon 220 (leg. Stepanov, LG), DNA-

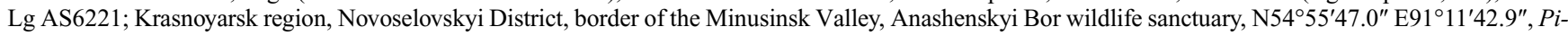
nus sylvestris + Betula pendula forest with grass and Pteridium pinetorum, N.V. Stepanov, 10 Jul 2017, Simon 219 (leg. Stepanov, LG), DNA-Lg AS6220; Kulumys ridge, near Aleev Kluch river, N53 $04^{\prime} 39.0^{\prime \prime}$ E93 $07^{\prime} 07.6^{\prime \prime}, 400 \mathrm{~m}$ above sea level, taiga (Abies sibirica + Pinus sibirica), on bark of Sorbus sibirica, N.V. Stepanov, 3 Jun 2017, Simon 215 (leg. Stepanov, LG), DNA-Lg AS6216; Kulumys ridge, near Chebizhek river, Pervaya Petlya locality, N5255'40.1" E93 ${ }^{\circ} 14^{\prime} 46.6^{\prime \prime}, 1020 \mathrm{~m}$ above sea level, taiga (Abies sibirica + Pinus sibirica), on bark of Sorbus sibirica, N.V. Stepanov, 3 Jun 2017, Simon 215 (leg. Stepanov, LG), DNA-Lg AS6217; Western Sayan, Kurtushibinskyi ridge, near the mouth of the Oresh River, N52 $28^{\prime} 01.2^{\prime \prime}$ E93 $29^{\prime} 44.7^{\prime \prime}, 1000 \mathrm{~m}$ above sea level, N.V. Stepanov, 11 Jul 2017, Simon 213 (leg. Stepanov, LG), DNA-Lg AS6214; Western Sayan, Ergaki ridge, basin of Nizhnyia Buyba River, Tarmazakovskyi, N52 ${ }^{\circ} 48^{\prime} 42.3^{\prime \prime}$ E $93^{\circ} 17^{\prime} 01.9^{\prime \prime}, 1350$ m above sea level, Pinus sibirica taiga with moss and Vaccinium myrtillus, on bark of Sorbus sibirica, N.V. Stepanov, 20 Aug 2017, Simon 214 (leg. Stepanov, LG), DNA-Lg AS6215; Komi Republic, Priluzsky District, approximately 4 km W of the ghost village of Pentjura (Пентюpa) and $11 \mathrm{~km}$ NW of Lojma (Лойма), N60³5'17.586" E48 37'39.21", on Sorbus trunk, in old mixedwood forest of Picea-Sorbus, A. Simon \& N. Semenova, 24 Aug 2017, Simon 178 (LG), DNA-Lg AS6191. U.S.A., Alaska, Chilkoot Trail, 59³4.608’ N 135 $19.880^{\prime} \mathrm{W}$, on Betula bark, 26 Jul 2008 , Spribille 26302 with S. Pérez-Ortega (KLGO), DNA extract T1276; Alaska, Glacier Bay National Park, Bartlett Cove, ca. $340 \mathrm{~m}$ NE of NPS docks, $58^{\circ} 27.463 ’ \mathrm{~N} 135^{\circ}$ $51.858^{\prime} \mathrm{W}$, on bark of Picea sitchensis twig at beach fringe, 4 Sep 2011, Spribille 36122 (MSC), DNA extract T1284; Glacier Bay National Park, East Arm of Glacier Bay, mouth of unnamed creek E of Muir Point, 58.83594 $\mathrm{N} 136.05309^{\circ} \mathrm{W}$, on Alnus bark, 30 Jul 2012, Spribille 39269 with A. Fryday \& M. Svensson (MSC), DNA extract T1285; Alaska, Tongass National Forst, small islet, S of Brownling Island, Ernst Sound, $55^{\circ} 55.330^{\prime} \mathrm{N} 132^{\circ} 10.271^{\prime} \mathrm{W}$, alt. $<3$ m, beachfringe forest, S aspect, bole of Alnus rubra, 3 Aug 2003, Dillman 2003-582 (CONN); Tongass National Forest, Mitkof Island, S of Petersburg, beachfringe forest across form the Stikine river delta, S aspect, $56^{\circ} 35.764^{\prime} \mathrm{N} 132^{\circ} 32.569^{\prime} \mathrm{W}$, alt. $<3 \mathrm{~m}$, on bole of Picea sitchensis, 29 Aug 2003 , Dillman 2003-1139 (CONN); Dillman 2003-1142 (CONN); Dillman 2003-1152 (CONN); Dillman 2003-1163 (CONN); Michigan, Keweenaw, Isle Royale National Park, Between Tonkin Bay and Conglomerate Bay, 3 Jul 1959, C.M. Wetmore 4239 (MSC 0142801); Minnesota, Cook, Seagull Creek, Gunflint Trail, Superior National Forest, 48 $07^{\prime} 34^{\prime \prime} \mathrm{N}, 90^{\circ} 51^{\prime} 51^{\prime \prime} \mathrm{W}, 2$ Jul 1974, C.M. Wetmore 22669 (MIN).

Dendriscosticta insinuans (Nyl.) Ant.Simon, Magain \& Sérus.

Additional specimens examined: JAPAN, Hokkaido Prefecture, Kawakami District, Shibecha experimental forest, old forest with a lot of dead wood, N43.35 ${ }^{\circ}$ E144.66 , c. $100 \mathrm{~m}$, on a wood along the river, in undergrowth with bracken fern, N. Magain with A. Saito \& S. Mori, 20 Aug 2019 , Simon 693 (LG, leg. Magain), DNA-LG 6430; Nakagawa-gun, Nakagawa, near Penkenai River, N44.835566 E142.137846 ${ }^{\circ}, 248$ m, on Tilia, A. Simon, N. Magain \& E. Sérusiaux, 6 Aug 2019, Simon 626 (LG), DNA-LG 6430; Nakagawa-gun, Otoineppu-mura, Kamiotoineppu, along Tenkita River and Road 275, N44.798973 E142.25779 143 m, on bark, A. Simon, N. Magain \& E. Sérusiaux, 5 Aug 2019, Simon 591 (LG), DNA-LG 6418; Simon 625 (LG), DNA-LG 6429; Sharigun, Shari-cho, Shiretoko National Park, along the trail from Iwaobetsu Onsen, N44.11 ${ }^{\circ}$ E145.09 ${ }^{\circ}$, c. $215-500 \mathrm{~m}$, old-growth montane forest, N. Magain with A. Saito \& S. Mori, 18 Aug 2019, Simon 685 (LG, leg. Magain), DNA-LG 6441; Urakawa-gun, Urakawa, Nobuka, on the trail towards Mt. Petekari starting from Petekari Sanso (ペテガリ山荘), N42.484997 E142.821997 , 883 m, on Betula, A. Simon, N. Magain \& E. Sérusiaux, 12 Aug 2019 , Simon 611 (LG), DNALG 6422; Honshu, Nagano Prefecture, Kiso-gun, Otaki, Hakkaisan, in the immediate vicinity of the ski resort Ontake 2240, on the south-eastern slopes of Mt Ontake, N35.861459 E137.531333, 1665 m, on Quercus, A. Simon \& E. Sérusiaux, 20 Aug 2019, Simon 611 (LG), DNA-LG 6422; Simon 668 (TNS), DNALG 6437.

Dendriscosticta oroborealis (Goward \& Tønsberg) Moncada \& Lücking

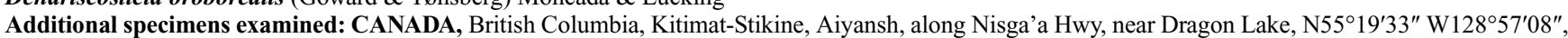
on Tsuga heterophylla, A. Simon \& T. Spribille, 28 Oct 2016, Simon 476 (LG); Kitimat-Stikine, in the vicinity of Kispiox Mountain, approximately 5 km NW of

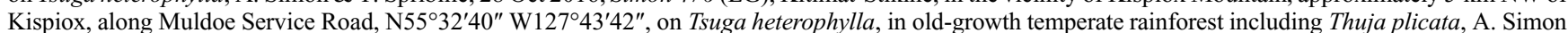
\& T. Spribille, 27 Oct 2016, Simon 472 (LG) \& Simon 475 (LG); Kitimat-Stikine, near Kispiox, N55 32.933' W127 $43.625^{\prime}$, on fallen small Tsuga heterophylla, 14 Sep 2008, Spribille 29815 (hb. Spribille), DNA T1269; Incomappleux River, 2.08 km NE of Beaton, steep NW-facing slope above mouth of river on Arrow Lake, N50.74829 $9^{\circ} 117.70948^{\circ}, 13$ Sep 2014, Spribille 40906 (hb. Spribille), DNA extract T1374; British Columbia, Robson Valley, Hungary Creek near highway, $53^{\circ} 52^{\prime} \mathrm{N} 121^{\circ} 32^{\prime} \mathrm{W}, 770 \mathrm{~m}$, on Tsuga branch, T. Spribille \& D. Radies, 5 Oct 2002, Goward 92-1973 (UBC, leg. Spribille), DNA extract UConn 1513; Robson Valley, slopes and gullies above Fraser River, $53^{\circ} 25^{\prime} \mathrm{N} 120^{\circ} 31^{\prime} \mathrm{W}, 885 \mathrm{~m}$, on Tsuga branch, T. Spribille \& D. Radies, 3 Oct 2002 , Goward 02-1725 (UBC, leg. Spribille), DNA extract UConn 1515; British Columbia, Columbia-Shuswap, Wood River, 34 km up logging road, $52^{\circ} 18^{\prime} \mathrm{N} 118^{\circ} 05^{\prime} \mathrm{W}$, open old-growth forest, on Tsuga branch, T Goward \& M. Zhurbenko, 24 Jul 2002, Goward 02-1091 (UBC), DNA extract UConn 1508. CHINA, Xizang, Milin Co., Lilong village, N29 11'17.31" E9402'19.44", 3044 m, L.S. Wang \& al. 19-66239 (KUN-L 70647), cyanomorph, on Quercus sp., 31 Jul 2019 ; Xizang, Chayu Co., Hydropower station in Guyu Town, N28 47' E97²8', 2465 m, cyanomorph, on rock, 24 Sep 2014, L.S. Wang \& al. 14-46421 (KUN-L 48369); Xizang, Basu Co., along the road from Ranwu to Chayu, N29¹9' E9657', 4563 m, cyanomorph, on Populus sp., 23 Sep 2014, L.S. Wang \& al. 14-46568 (KUN-L 48516); Yunnan, Tengchong Co., Houqiao village, N25¹1' E98 ${ }^{\circ} 19^{\prime}, 1910 \mathrm{~m}$, L.S. Wang \& al. 12-33402, cyanomorph, on bark, $28 \mathrm{Mar} 2012$; Wang 12-33394 (KUN-L), Wang 12-33380 (KUN-L); Yunnan, Jingdong Co., Wuliangshan Mt., N24 $19^{\prime}$ E100 $47^{\prime}, 2420$ m, cyanomorph, on bark, 20 Jun 2005 , Wang 05-23533 (KUN-L); Yunnan, Lijiang Co., Laojunshan Mt., N26³9' E9946', 3690 m, cyanomorph, on bark of Abies, 28 Aug 2005, L.S. Wang \& al. 05-25299 (KUN-L); Yunnan, Deqin Co., Baimaxueshan Mt., N28 $19^{\prime}$ E99 05', 4350 m, cyanomorph, on rock, 2 Nov 2015, L.S. Wang \& al. 15-49652 (KUN-L); Yunnan, Zhongdian Co., Geza village, Xiaoxueshan Mt., N28¹7'08.35" E99²5'58.20", 3461 m, cyanomorph, on Salix, 5 Jul 2012, L.S. Wang \& al. $12-34903$ (KUN-L). Dendriscosticta phyllidiata Ant.Simon, Goffinet \& Sérus.

Additional specimens examined: TAIWAN, Chiayi County, Alishan Township, Alishan range, Alishan National Forest area, Apine botanic garden, N23 ${ }^{\circ}$ $30.149^{\prime}$ E120 $49.367^{\prime}, 2480-2500 \mathrm{~m}$, on large maple, below alpine garden, B. Goffinet \& E. Sérusiaux, 25 Oct 2016, Goffinet 13506 (topotype, CONN), 


\section{Appendix 2. Continued.}

DNA-UConn 4748; Goffinet 13508 (topotype, CONN), DNA-UConn 4749; Taroko National Park, Hualien County, Xiulin Township, Fushi village, off Hwy 8, $\mathrm{N}$ of intersection with Hwy 14a, trail to Mount Pilu, starting immediately $\mathrm{N}$ of tunnel, $\mathrm{N} 24^{\circ} 10.949^{\prime} \mathrm{E} 121^{\circ} 18.490^{\prime}$, trail through mixedwood montane forest and Pinus forests, E. Sérusiaux \& B. Goffinet, 20 Oct 2016, Sérusiaux s.n. (LG), DNA-218T; DNA-228T.

Dendriscosticta platyphylloides (Nyl.) Moncada \& Lücking

Additional specimens examined: CHINA, Sichuan, Kangding Co., Mugecuo nature reserve, Rhododendron valley, N30 08'35.93" E10151'35.27", 2790 m, on Abies bark, L.S. Wang, X.Y. Wang, H.X. Shi, M.X. Yang 16-52649 (KUN-L 56069); Xizang, Bomi Co., along the road from Bomi to Ranwu, N2948.412' E95 ${ }^{\circ}$ 49.114', $2811 \mathrm{~m}$, on deadwood, 2 Sep 2014, Wang 14-46264 (KUN-L 48212); Wang 14-46249 (KUN-L 48197); Xizang, Chayu Co., Hydropower station in Guyu Town, N28 54.729' E97²8.293', 2904 m, on rock, L.S. Wang, J. Wang, H.X. Shi, 24 Sep 2014, Wang 14-46434 (KUN-L 48382); Xizang, Chayu Co., Sangjiu village, N28 47.631' E97²9.905', 2709 m, on bark, 25 Sep 2014, Wang 14-46791 (KUN-L 48739); Xizang, Chayu Co., Muruo village, N28 ${ }^{\circ}$ 35.267' E98 01.503', 3912 m, on Sorbus, 26 Sep 2014, Wang 14-46730 (KUN-L 48678); Xizang, Bomi Co., Dongqu village, N2943.891' E96 02.069', 3052 m, on Quercus, 21 Sep 2014, Wang 14-46283 (KUN-L 48231); Xizang, Chayu Co., Hydropower station in Guyu Town, N28 54.729’ E97²8.293', 2904 m, on stump, 24 Sep 2014, Wang 14-46510 (KUN-L 48458); Xizang, Chayu Co., Muruo village, N28 $35.267^{\prime}$ E9 $8^{\circ} 01.503^{\prime}, 3912$ m, on bark, 26 Sep 2014, Wang 14-46725 (KUN-L 48673); Xizang, Bomi Co., Dongqu village, N2943.891' E9602.069', 3052 m, on Quercus, 21 Sep 2014 , Wang 14-46287 (KUN-L 48235); Xizang, Bomi Co., Guxiang village, N2953'58.02" E95³0.27.65", 2680 m, on Quercus, 24 Sep 2016, L.S. Wang, X.Y. Wang, H.X. Shi, M.X. Yang 16-54413 (KUN-L 57833); Xizang, Linzhi Co., on the way from Bomi to Linzhi, near G318 road, N2952'18.20" E94'46'31.81", 2860 m, on Sorbus bark, 24 Sep 2016, Wang 16-53660 (KUN-L 57080); Xizang, Linzhi Co., on the way from Bomi to Linzhi, beside G318 road, N29 52'18.20" E94²46'31.81", 2860 m, on Lonicera bark, 24 Sep 2016, L.S. Wang (KUN-L 57104); Yunnan, Lijiang Prefecture, Lijiang Co., S of Lijiang, Jiuhue village, along trail from parking lot to peak, N26 $39.218^{\prime} \mathrm{E} 99^{\circ} 46.585^{\prime}, \pm 3451 \mathrm{~m}$, montane forest dominated by Abies and further up by Rhododendron, B. Goffinet, LS. Wang, S.L. Guo \& S.Y. Huang, 16 Jul 2010, Goffinet 9971 (CONN), DNA extract UConn 2939.

Dendriscosticta praetextata (Räsänen) Moncada \& Lücking

Additional specimens examined: CHINA, Xizang, Chayu Co., Sangjiu village, N2847.631' E97²9.905', 2709 m, on rock, 25 Sep 2014 , Wang 14-46806 (KUN-L 48754); Xizang, Bomi Co., Gang village, N2952.983' E95³3.593', 2688 m, on rock, 20 Sep 2014, Wang 14-46154 (KUN-L 48102); Xizang, Chayu Co., Sangjiu village, N28 $47.631^{\prime}$ E97 $29.905^{\prime}, 2709$ m, on rock, 25 Sep 2014, Wang 14-46812 (KUN-L 48760); Xizang, Chayu Co., along the road from Muruo village to Bingzhongluo, N28 $35.781^{\prime}$ E98 $06.404^{\prime}, 3833$ m, on stump, 26 Sep 2014, Wang 14-46774 (KUN-L 48722); Xizang, Bomi Co., Gang village, N29 ${ }^{\circ}$ 52.983' E95'33.593', 2688 m, on Pinus yunnanensis, 20 Sep 2014, Wang 14-46218 (KUN-L 48166); Xizang, Chayu Co., along the road from Muruo village to Bingzhongluo, N2335.781', E9806.404', 3833 m, on bark, 26 Sep 2014, Wang 14-46779 (KUN-L 48727); Xizang, Bomi Co., Gang village, N2952.983' E95

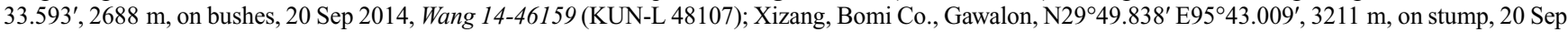
2014, Wang 14-46081 (KUN-L 48029); Xizang, Chayu Co., Luoma village, N2901.571' E97'22.795', 2930 m, on Salix, 23 Sep 2014, Wang 14-46702 (KUN-L 48650); Xizang, Bomi Co., along the road from Bomi to Ranwu, N2948.412' E95²49.114', $2811 \mathrm{~m}$, on Quercus, 21 Sep 2014, Wang 14-46246 (KUN-L 48194); Xizang, Bomi Co., Dongqu village, N2943.891' E96 02.069', 3052 m, on Quercus, 21 Sep 2014, Wang 14-46281 (KUN-L 48229); Xizang, Chayu Co., Hydropower station in Guyu Town, N28 54.729' E97²8.293, 2904 m, on rock, 24 Sep 2014, Wang 14-46496 (KUN-L 48444); Xizang Chayu Co., Hydropower station in Guyu Town, N28 47.363' E97'28.983', 2465 m, on rock, 24 Sep 2014, Wang 14-46400 (KUN-L 48348); Yunnan Province, Weixi Co., on the way of

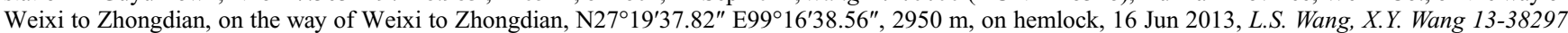
(KUN-L 24008). INDIA, Uttarakhand, Uttarkashi District, Harkidun forest guest house, N31 ${ }^{\circ} 08^{\prime} 22.17^{\prime \prime}$ E78 $24^{\prime} 30.56^{\prime \prime}, 3205$ m, on Abies, D.K. Upreti \& R. Bajpai, 11 Jun 2012, Upreti 12-011438 (LG), DNA-Lg 3168.

Dendriscosticta wrightii (Tuck.) Moncada \& Lücking

Additional specimens examined: JAPAN, Honshu, Yamanashi Prefecture, en route from Kitazawa Pass to Sensui Pass, Minami-Alps-city, N35 $44^{\prime 2} 2.0^{\prime \prime}$ E138 $13^{\prime} 05.2^{\prime \prime}, 2010 \mathrm{~m}$, on bark of Salix sp., Y. Ohmura \& A. Frisch, 28 Jun 2012, Y. Ohmura 8954 (TNS), DNA-LG AS6209. SOUTH KOREA,

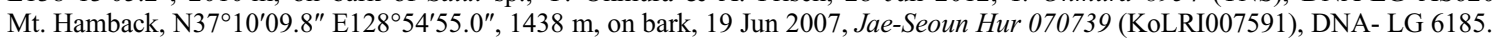

Dendriscosticta yatabeana (Müll.Arg.) Ant.Simon, Goffinet \& Sérus.

Additional specimens examined: CHINA, Xizang, Bomi Co., Guxiang village, forest near G 318 road, N29 53'58.02" E95'30'27.65", 2680 m, on Pinus bark, L.S. Wang, X.Y. Wang, H.X. Shi, M.X. Yang 16-52075 (KUN-L); 16-52004 (KUN-L); Xizang, Chayu Co., Hydropower station in Guyu Town, N28 $54.729^{\prime}$ E97 28.293', 2904 m, on rock, L.S. Wang, J. Wang \& H.X. Shi, 24 Sep 2014, Wang 14-46445 (KUN-L 48393), DNA extract UConn 3944; Shangri-la Co. N of Shangri-la, Xiao Xueshan Mountain, along road from Shangri-la to Sichuan, Geza village, N28 $16^{\prime} 49.90^{\prime \prime}$ E99 $45^{\prime} 35.52^{\prime \prime}, 3289$ m, along stream in secondary woodland and in Abies woodland, Goffinet 10772 (CONN), DNA extract UConn 4170. JAPAN, Hokkaido Prefecture, Kawakami District, Shibecha experimen-

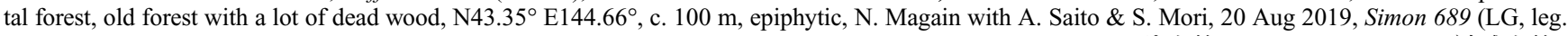
Magain), DNA-LG 6444; Urakawa-gun, Urakawa, Nobuka, on the trail between Petekari Sanso (ペテガリ山荘) and Kamui Sanso (神威山荘), N42.452584 ${ }^{\circ}$ E142.846037, $547 \mathrm{~m}$, on Fraxinus in a young conifer plantation, A. Simon, N. Magain \& E. Sérusiaux, 12 Aug 2019 , Simon 613 (LG), DNALG 6423; Honshu, Fukushima Prefecture, Yama District, Kitashiobara, Hibara, on the ski slope at Grandeco Snow Resort, N37.717553 E140.129157 1384 m, on Fagus, A. Simon \& E. Sérusiaux, 24 Aug 2019, Simon 673 (LG), DNA-LG 6439; Yamanashi Prefecture, en route from Kitazawa Pass to Sensui

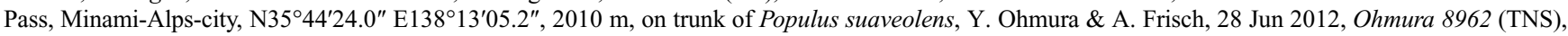
DNA-LG AS6209. SOUTH KOREA, Sodo-dong, Taebaek-si, Gangwon-do, N37 05'46.5" E128 57'04.4", 1415 m, 23 Dec 2014 , S.O. Oh, J.S. Park, J.J. Woo 141578 (KoLRI032251), DNA-LG AS6189. TAIWAN, Hualien County, Xiulin Township, Fushi village, Taroko National Park, about 2.7 km on Hwy 14a past the high elevation endemic research institute, $\mathrm{N} 24^{\circ} 10.717^{\prime}, \mathrm{E} 121^{\circ} 18.264^{\prime}, 2750 \mathrm{~m}$, trail through deciduous upper montane forest with dense bamboo undergrowth, grading into Pinus forest with willows along the trail, B. Goffinet \& E. Sérusiaux, 19 Oct 2016, Goffinet 13214, DNA extract UConn 4737; Goffinet 13227 (CONN), DNA extract UConn 4738. 